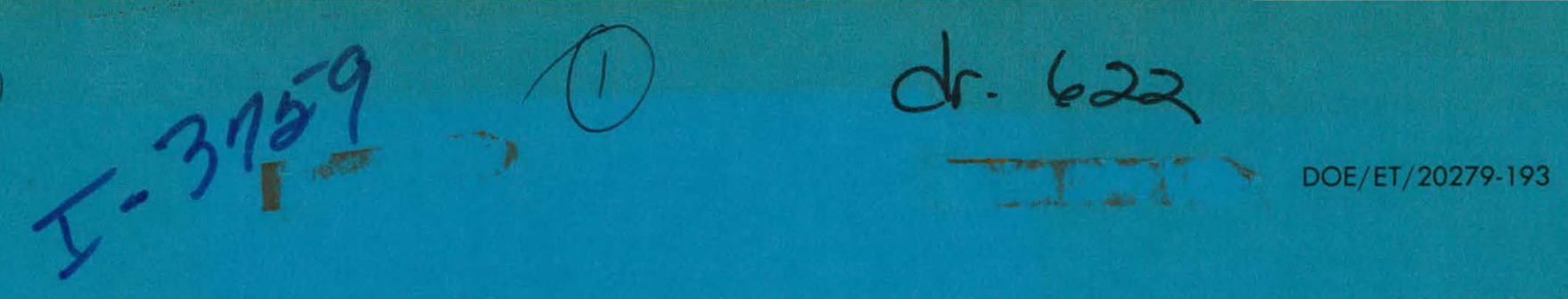

General Electric Final Report:

DESIGN AND FABRICATION OF A PROTOTYPE SYSTEM

FOR PHOTOVOLTAIC RESIDENCES

IN THE SOUTHWEST

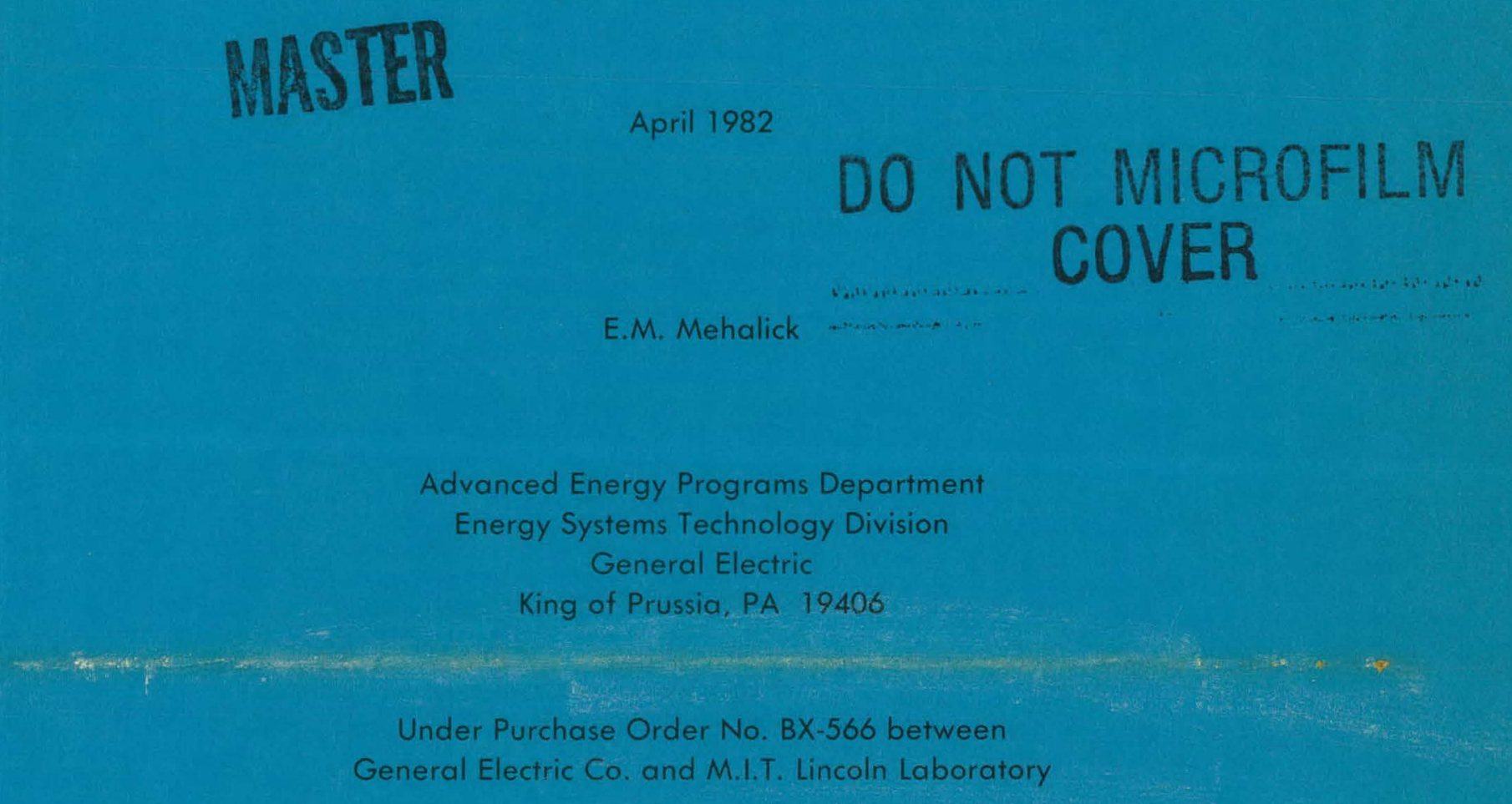

Massachusetts Institute of Technology Lincoln Laboratory

Lexington, Massachusetts 02173-0073

Prepared for

THE U.S. DEPARTMENT OF ENERGY

UNDER CONTRACT NO. DE-AC02-76ET20279 


\section{DISCLAIMER}

This report was prepared as an account of work sponsored by an agency of the United States Government. Neither the United States Government nor any agency Thereof, nor any of their employees, makes any warranty, express or implied, or assumes any legal liability or responsibility for the accuracy, completeness, or usefulness of any information, apparatus, product, or process disclosed, or represents that its use would not infringe privately owned rights. Reference herein to any specific commercial product, process, or service by trade name, trademark, manufacturer, or otherwise does not necessarily constitute or imply its endorsement, recommendation, or favoring by the United States Government or any agency thereof. The views and opinions of authors expressed herein do not necessarily state or reflect those of the United States Government or any agency thereof. 


\section{DISCLAIMER}

Portions of this document may be illegible in electronic image products. Images are produced from the best available original document. 
This book was prepared as an account of work sponsored by an agency of the United States Government. Neither the United States Government nor any agency thereof, nor any of their employees, makes any warranty, express or implied, or assumes any legal liability or responsibility for the accuracy, completeness, or usefulness of any information, apparatus, product, or process disclosed, or represent that its use would not infringe privately owned rights. Reference herein to any specific commercial product, process, or service by trade name, trademark, manafacturer, or otherwise, does not necessarily constitute or imply its endorsement, recommendation, or favoring by the United States Government or any agency thereof. The views and opinions of authors expressed herein do not necessarily state or reflect those of the United States Government or any agency thereof.

Additional copies available from the National Technical Information Service, U.S. Department of Commerce, Springfield, Virginia 22161.

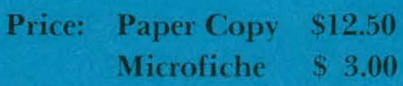


General Electric Final Report:

\section{DESIGN AND FABRICATION OF A PROTOTYPE SYSTEM}

FOR PHOTOVOLTAIC RESIDENCES

IN THE SOUTHWEST

April 1982

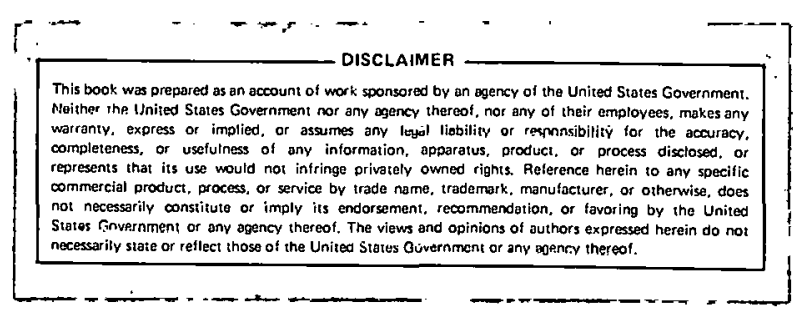

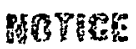

E.M. Mehalick

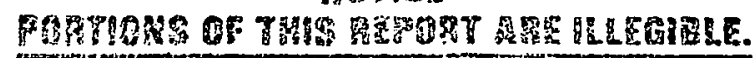

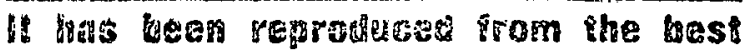
uyalatole copy to permil the broacest: passiblo avallabiliey.

Advanced Energy Programs Department

Energy Systems Technology Division

General Electric

King of Prussia, PA 19406

Under Purchase Order No. BX-566 between

General Electric Co. and M.I.T. Lincoln Laboratory

Massachusetts Institute of Technology

Lincoln Laburatory

Lexington, Massachusetts 02173-0073

Prepared for

THE U.S. DEPARTMENT OF ENERGY

UNDER CONTRACT NO. DE-ACO2 76ET20279 


\section{THIS PAGE}

\section{WAS INTENTIONALLY \\ LEFT BLANK}


ABSTRACT

A photovoltaic (PV) system has been designed and integrated into a residential home suitable for the Southwest region of the country. This report describes the house design and the PV system design which incorporates a unique shingle PV module developed by General Electric Company. The system has been installed and is currently being tested by New Mexico Solar Energy Institute (NMSEI) on a prototype structure at the Southwest Residential Experiment Station in Ias Cruces, New Mexico.

The photovoltaic system is grid connected and is designed to meet both space conditioning requirements and all conventional electrical load requirements for an all-electric residence. The PV system consists of two major subsystems, the solar array and the power conversion subsystem. A 6.7-kW-peak power rating (100 $\mathrm{mW} / \mathrm{cm}^{2}, 25^{\circ} \mathrm{C}$ cell temperature) photovoltaic array has been designed for the house. The $73.3 \mathrm{~m}^{2}$ of exposed solar array module area uses 375 direct-mounted shingle modules in a 25 seriea by 15 parallel network. The photovoltaic generated power is supplied to an Abacus 6-kW-output-rated dual-bridge inverter, which is controlled to approximately track the solar array maximum-power, operating point through an open-loop pilot-cell algorithm. The inverter feeds the 240-VAC output power directly to the house loads or back to the utility when excess is generated. The DC power is isolated from the utility by a transformer within the power conditioning unit. The system operation is automatic and the output is synchronized with lie utility. The system automatically shuts down with loss of utility. The overall system is connected in parallel with the ut1lity service to supply the residential load.

The installation of the modules was completed as planned by a local contractor without any problems. No module damage occurred during installation or in shipping and the measured array output was slightly above predictions. The complete installation was considered a success. 
THIS PAGE

\section{WAS INTENTIONALLY \\ LEFT BLANK}




\section{ACKNOWLEDGMENTS}

The residential photovoltaic (PV) system design described in this report is a result of contributions of several individuals from different organizations. The basic system design evolved from several previous studies performed by the General Electric Company for Sandia National Laboratories. The team formed for this project was led by the Advanced Energy Programs Department (AEPD) of the General Electric Company. AEPD had responsibility for the PV system design, the module fabrication, and program management. Massdesign, Architects and Planners, Inc., of Cambridge, Massachusetts, designed the residence and prototype structure. Alley-Connell and Associates, Roswell, New Mexico, provided on-site prototype structure design guidance and installation supervision. Johnson and Stover, Inc., of Middleborough, Massachusetts, developed the electrical system design drawings and specifications. The electrical system was installed by Forrester Construction Company of Las Cruces, New Mexico.

Mr. E. Mehalick of General Electric served as the Program Manager. The GE team included: Mr. N. Shepard who designed the PV Shingle module; Mr. G. O'Brien who lead the overall syotem design; Mr. E. Komito who calculated the system performance; Mr. J. Chan who supported the design review and final report and $\mathrm{Mr}$. C. Romig and $\mathrm{Mr}$. R. Collingwood who were responsible for system installation and checkout. In addition, the GE module manufacturing team was led by $\mathrm{Mr}$. J. Wright.

Mr. G. Tully was the principal contributor from Massdesign and Mr. J. Johnson was the individual contributor from Johnson and Stover. The program could not have been a succoes withnut each individual contribution.

Dr. J. Schaefer of New Mexico Solar Energy Institute was the program monitor and provided continual guidance. Mr. G. Hocking of NMSEI also provided on-site checkout and maintenance support during the inverter upgrading time period. His help saved many trips to the site by GE personnel. 
THIS PAGE

\section{WAS INTENTIONALLY LEFT BLANK}


TABLE OF CONTENTS

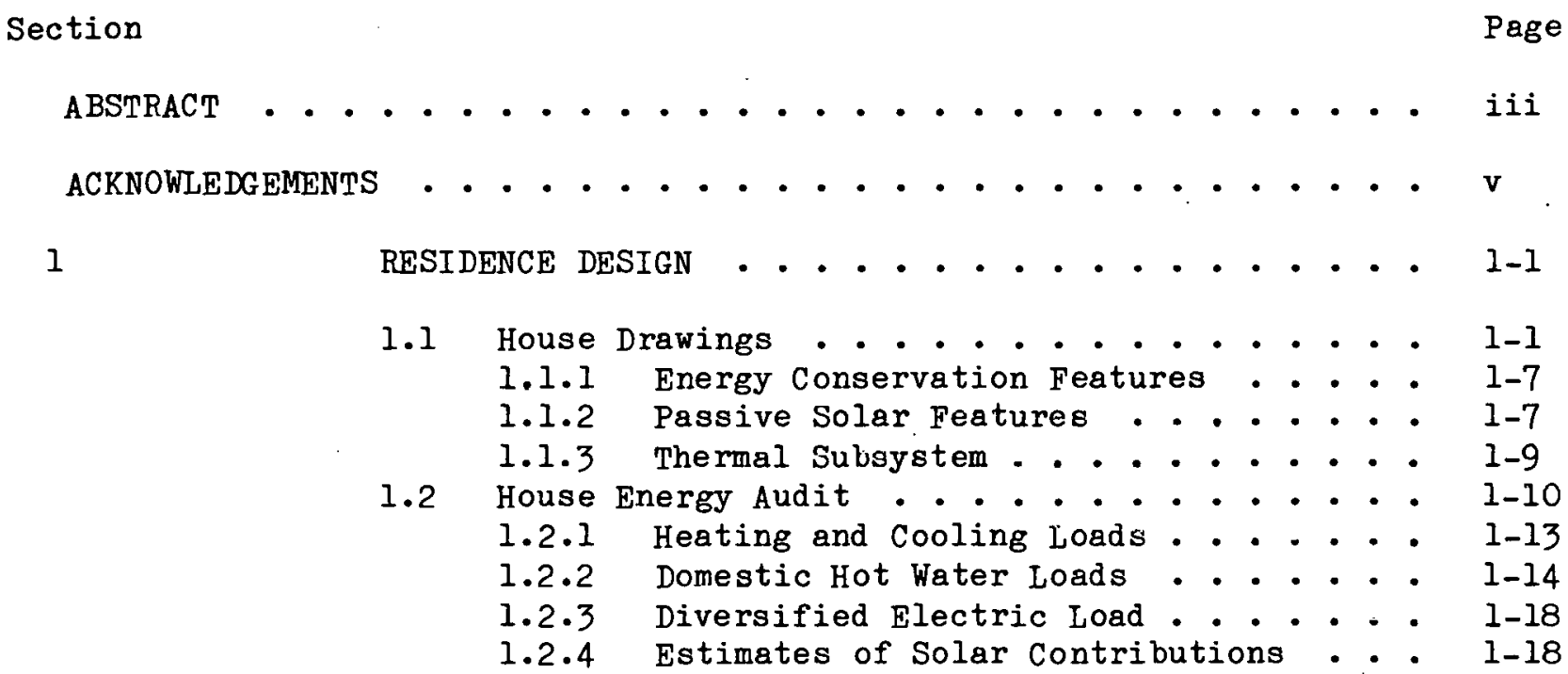

PROTOTYPE SYSTEM DESCRIPTION . . . . . . . . 2-I

2.1 Structural Design ............. 2-1

2.2 Mechanical Design ............ 2- . .

2.2.1 Module Physical Details . . . . . 2-9

2.2.2 Module Mounting Details ....... 2-14

2.2.3 Module Mounting Procedure ..... . 2-16

2.2.4 Inverter Physical Details . . . . . 2-18

2.2.5 Inverter Installation Requirements . . 2-2l

2.3 Electrical Design . . .......... 2-21

2.3.1 Module Electrical Characteristics . . 2-25

2.3.2 Array Electrical Configuration . . . 2-26

2.3.3 System Electrical Details..... 2-32

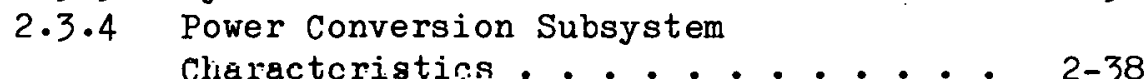

3 PROTOTYPE FABRICATION HISTORY/LESSONS LEARNED • • • 3-1

3.1 Modules . . . . . . . . . . 3-1

3.1.1 Manufacture ........... 3-1

3.1 .2 Shipping .............. 3-4

3.1.3 Module Installation ....... 3-6

3.2 Power Conversion Subsystem ....... 3-9

3.2.1 Manufactire/Procurement ...... 3-9

3.2.2 Shipping ............ 3-9

3.2.3 Installation ......... 3-9

3.3 System . . . . . . . . . . . 3-9

3.3.1 Final Checkout Procedure ...... 3-9

3.3.2 Operation and Maintenance Procedures - 3-12

3.3.3 Cost Information ........ 3-16 
TABLE OF CONTENTS (Cont.)

Section

4

APPENDIX A:

APPENDIX B:

APPENDIX C:

APPENDIX D:
Page

REFERENCES . . . . . . . . . . . 4-1

INSTALLATION SAFETY NOTES FOR PHOTOVOLTAIC SHINGLE

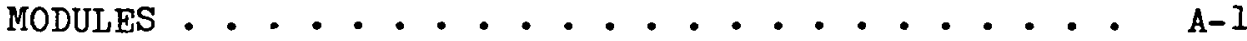

ELECTRICAL SYSTEM INSTALLATION SPECIFICATIONS ... B-1 ABACUS CONTROLS SUNVERTER SPECIFICATIONS . . . . C C

GE HOT WATER BANK INFORMATION SHEET. ... .... . D-1 


\section{LIST OF FIGURES}

Figure

Perspective of the Southwest Residence . . . . . . . . 1-2

$1-2$ Elevation and Section of Residence ............ . . 1-4 Elevations of the Residence . . . . . . . . . . . . 1-5 Floor Plan . . . . . . . . . . . . . . . . . $1-6$

Shingle Module Construction Details $0^{\circ}$ 
System Wiring Schematic $2-35$

Block IV Shingle Module Manufacturing Facility . . . . . .

\section{LIST OF TABLES}

Table

Single-Family Monthly Load Profile . . . . . . . . . .

Major Electrical Equipment List . . . . . . . . . . . .

Array Installation Labor . . . . . . . . . . . . 3-6

Array Wiring Labor . . . . . . . . . . . . . . 3-6

Power Conditioner Installation and Wiring Labor . . . . . . 3-10 Diagnostic Procedure for Defective Modules . . . . . . . . 3-14 
SECTION 1

RESIDENCE DESIGN

This section of the report presents a design of a single-family detached photovoltaic residence appropriate for the Southwest. The report includes both a complete description of the house design with the equipment for heating and cooling, domestic hot water and all electrical load equipment and a description of the photovoltaic system which can be integrated into the housing design. Figure 1-1 shows a perspective of the house. The following sections describe each of the key aspects of the residence design.

\subsection{HOUSE DRAWINGS}

Massdesign, Architects and Planners, Inc., has developed an energy conserving, passive house design to suit a variety of Southwest conditions. In the early stages of $\mathrm{PV}$ systems, it is important to consider house designs which provide widespread application potential for the design versions of the house, appropriate to the Southwest area. The house uses a mixture of frame and adobe construction, whereas elsewhere the same design could be built with wood and concrete block. This flexibility of the house design provides the potential for a more widespread application of the design for eventual large-scale PV system implementation.

In response to the need for small yards in hot, dry climates and to the growing popularity of zero-lot-line designs (those in which the building touches the lot-line on one or more sides), the house is a "patio-house" design. This means that instead of the huuse "floating" in the middle of a lot, with non-private and relatively useless spaces on all sides, the house is built against walls or fences at the lot line, enclosing a number of courts or patios. The advantages of this approach are

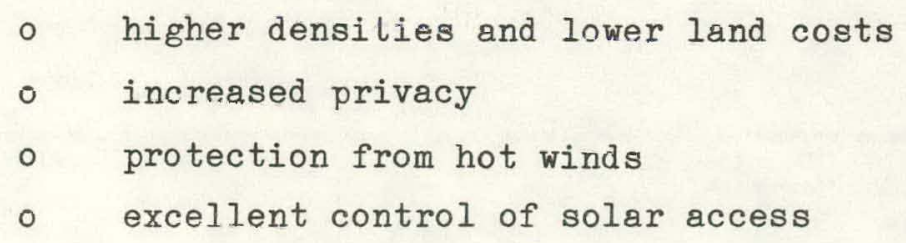

Because only the solar roof rises above the prevailing building and wall height, similar houses can be adjacent and still not shade each other. 


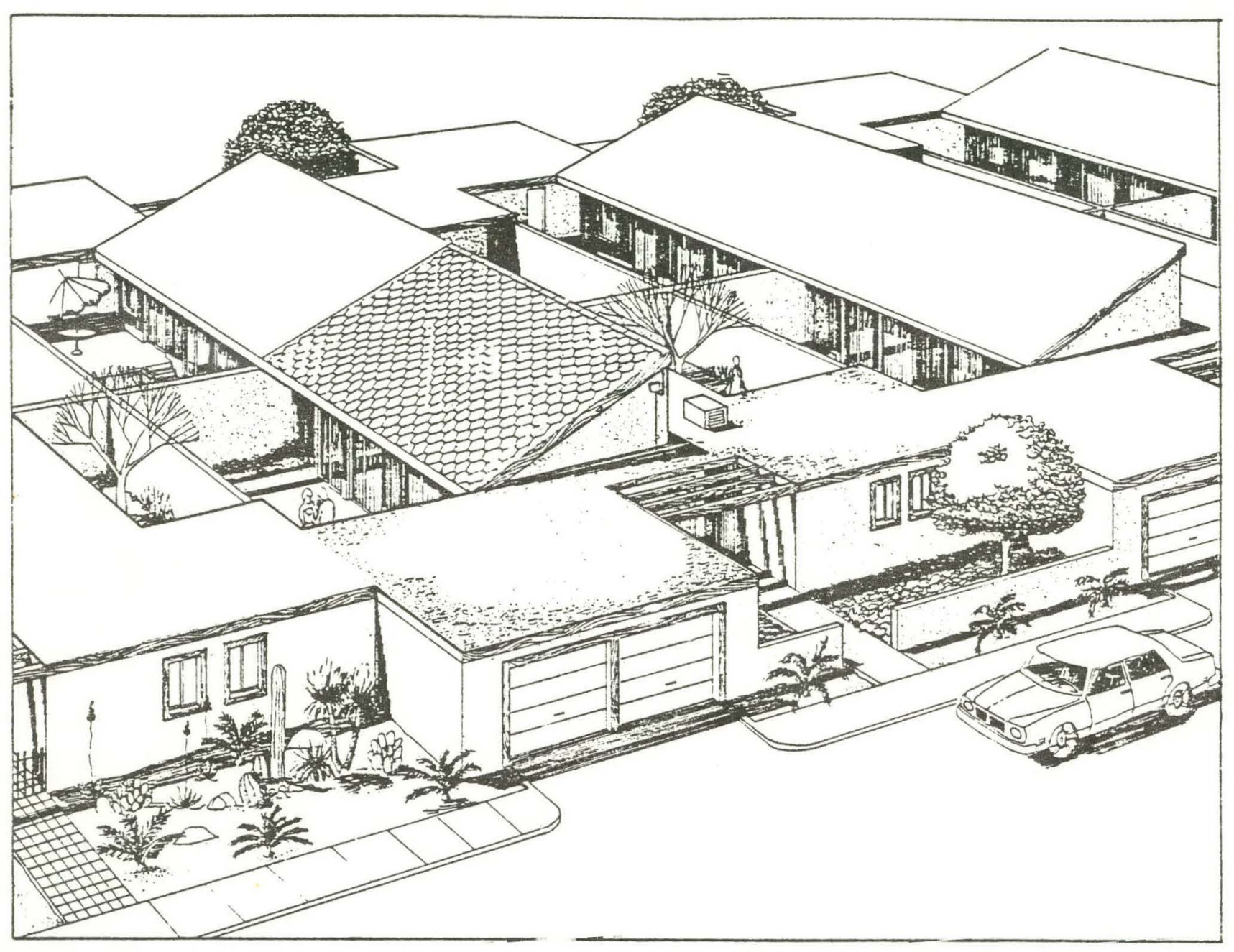

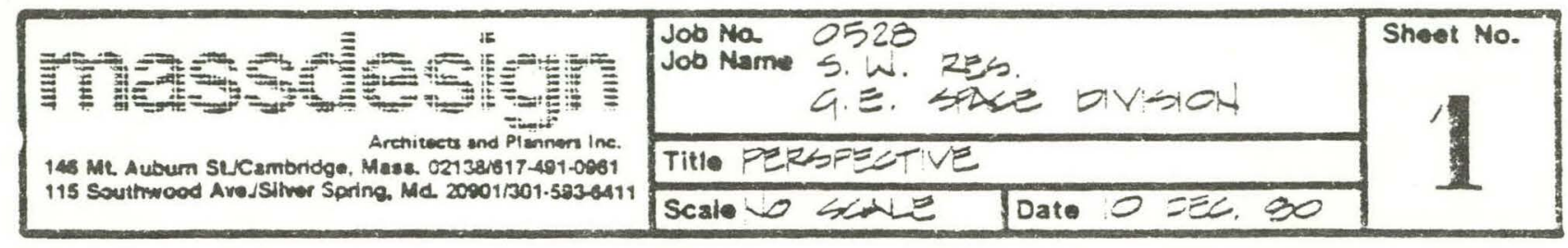

Figure 1-1. Perspective of the Southwest Fesidence 
Figures 1-2 and 1-3 show the four elevations of the design. The south elevation shows a continuous rectangular roof area facing south at a $6 / 12$ pitch, totally unshaded to accommodate the photovoltaic array. The roof is $12.8 \mathrm{~m}$ (42 $\mathrm{ft}$ ) in length and $6.65 \mathrm{~m}(21.8 \mathrm{ft})$ in slant height for a total available roof area of $85.1 \mathrm{~m}^{2}\left(916 \mathrm{ft}^{2}\right)$.

The plan, Figure 1-4, includes 3 bedrooms, 2 full baths, a kitchen, a dining room, a living room, storage, and an equipment room, all on one story, in an area of $162.7 \mathrm{~m}^{2}$ (1750 $\mathrm{ft}^{2}$ ). A 2-car garage or carport at the southeast or southwest corners forms one side of two courts. The street is located on the east (or west if the plan is reversed). It is also possible for the street to be on the south by rotating the garage to face south. A north street frontage is possible by widening the lot in the east-west direction to allow a driveway and walk to the east of the master bedroom. Thus the design provides a great deal of flexibility for siting on a given lot.

The service drop must pass into a conduit and run concealed into the building and under the slab into the equipment room. Power conditioning equipment is located on the south wall of the equipment room. A disconnect switch is located on the side wall of the high roof, accessible by a person standing on the lower flat roof.

The building is entered from the end, which requires a passageway to reach the other end. This passageway takes the form of a gallery open to the living and eating spaces lhrough an arcade of wood. At the end of the gallery is a skylit space leading to the two smaller bedrooms and adjacent baths. The mastor bedroom suite is in a separate wing to the right as you enter the house. The equipment room is also to the right of the entry, opposite the kitchen.

The living room is sunken $40.6 \mathrm{~cm}$ ( 16 inches) below the rest of the house. Combined with the cathedral ceiling, an arcade surrounding the dining room, and the adjacent gallery, the overall effect will be dramatic and reminiscent of older southwestern houses. No attempt has been made to imitate exactly these old buildings, because they are all very climate specific; whereas, this design can look appropriate in regions throughout the Southwest. 


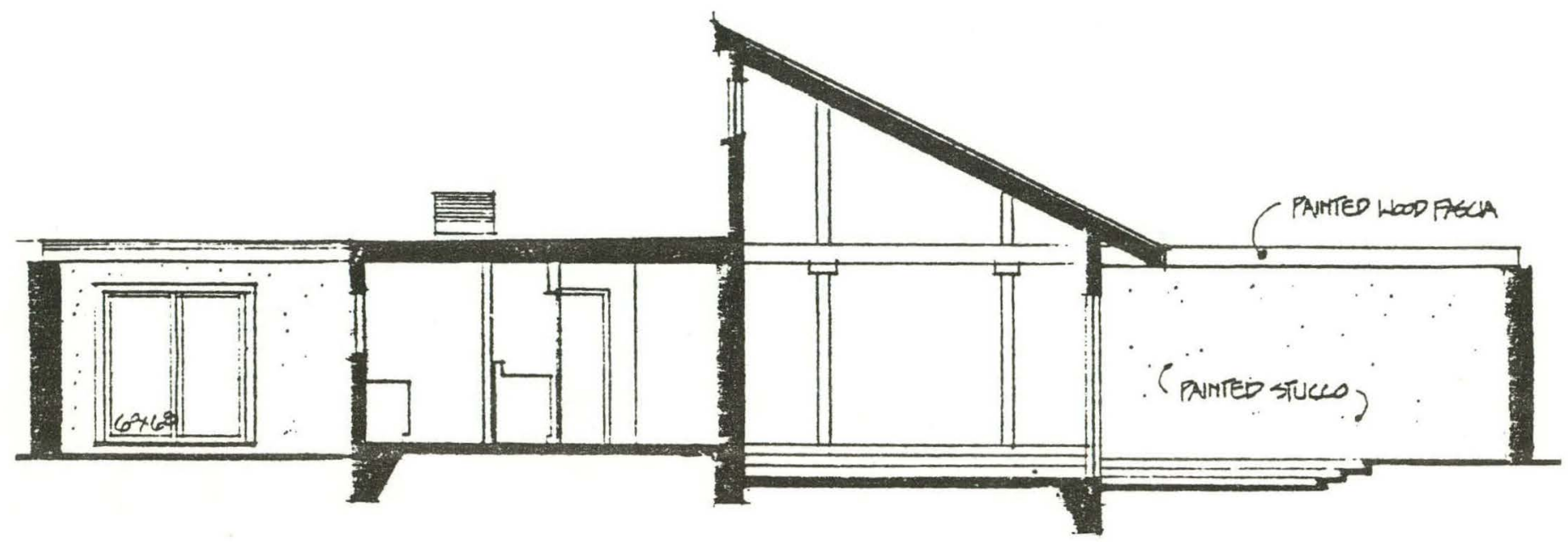

SECTION C.C

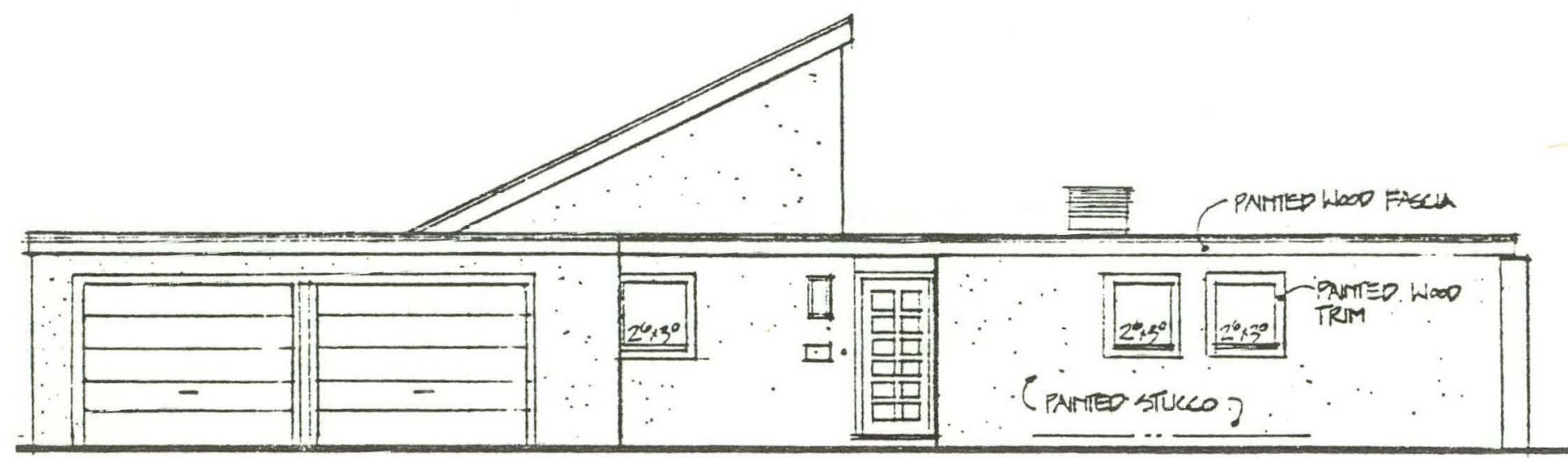

ENTRY

ELEVATION

\begin{tabular}{|c|c|c|}
\hline \multirow{3}{*}{$\begin{array}{l}138 \text { Mt. Auburn St. / Cambridgo, Mast. 02138/ } 617-491-0961 \\
115 \text { Southnood Ave. / Silver Soring, Md. } 20901 / 301.593-6411\end{array}$} & $\begin{array}{l}\text { Job Na OEZBP } \\
\text { Job Name S.W. RES } \\
\text { G.E. SPACE DM. }\end{array}$ & \multirow[t]{3}{*}{ Sheet No. } \\
\hline & SECTIONEELEVATIO & \\
\hline & Scale $/ / z^{\prime}=1^{\prime}-O^{\prime \prime}$ & \\
\hline
\end{tabular}

Figure 1-2. Elevation and Section of Residence 


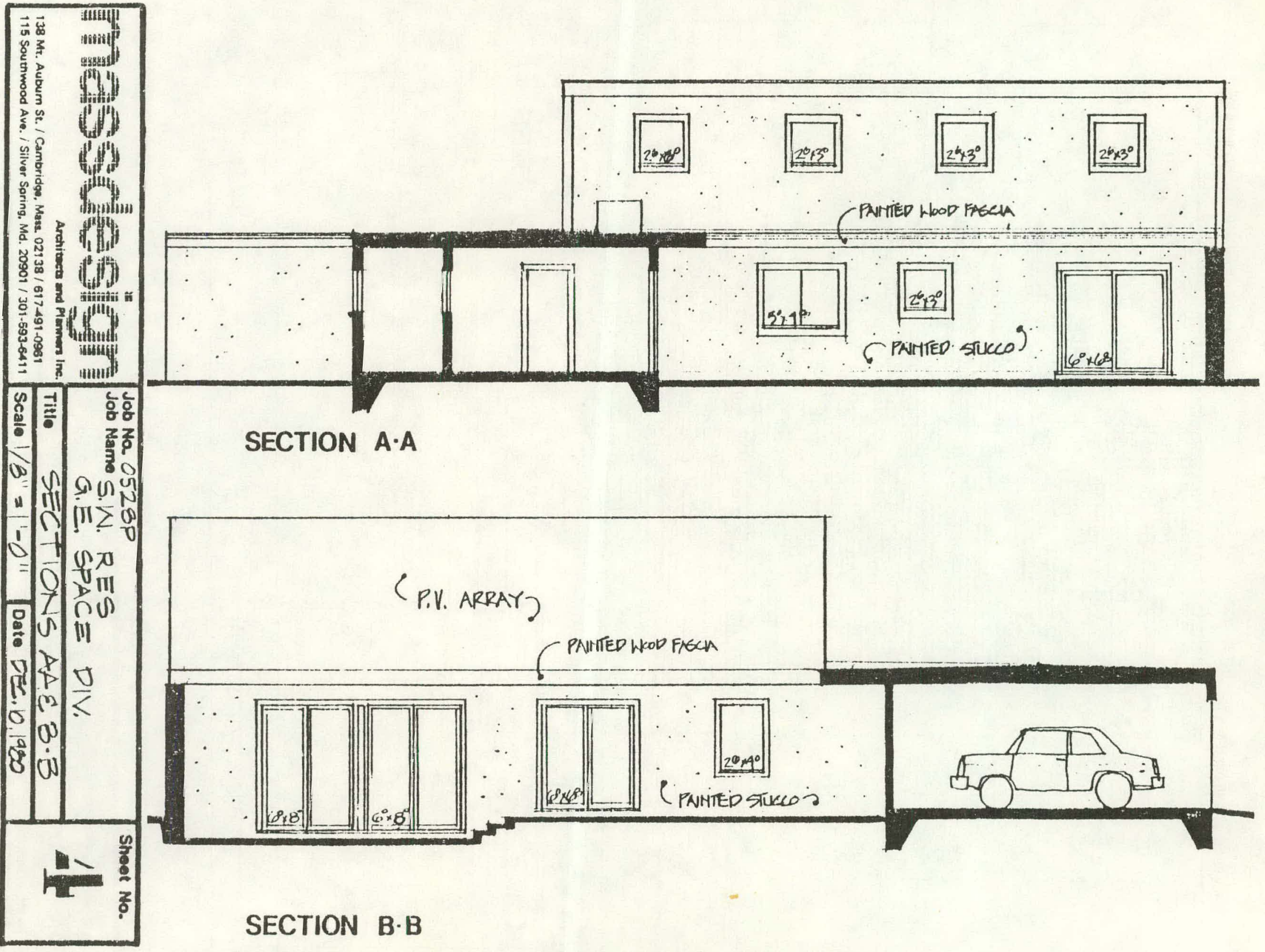

Figure 1-3. Elevations of the Residence 


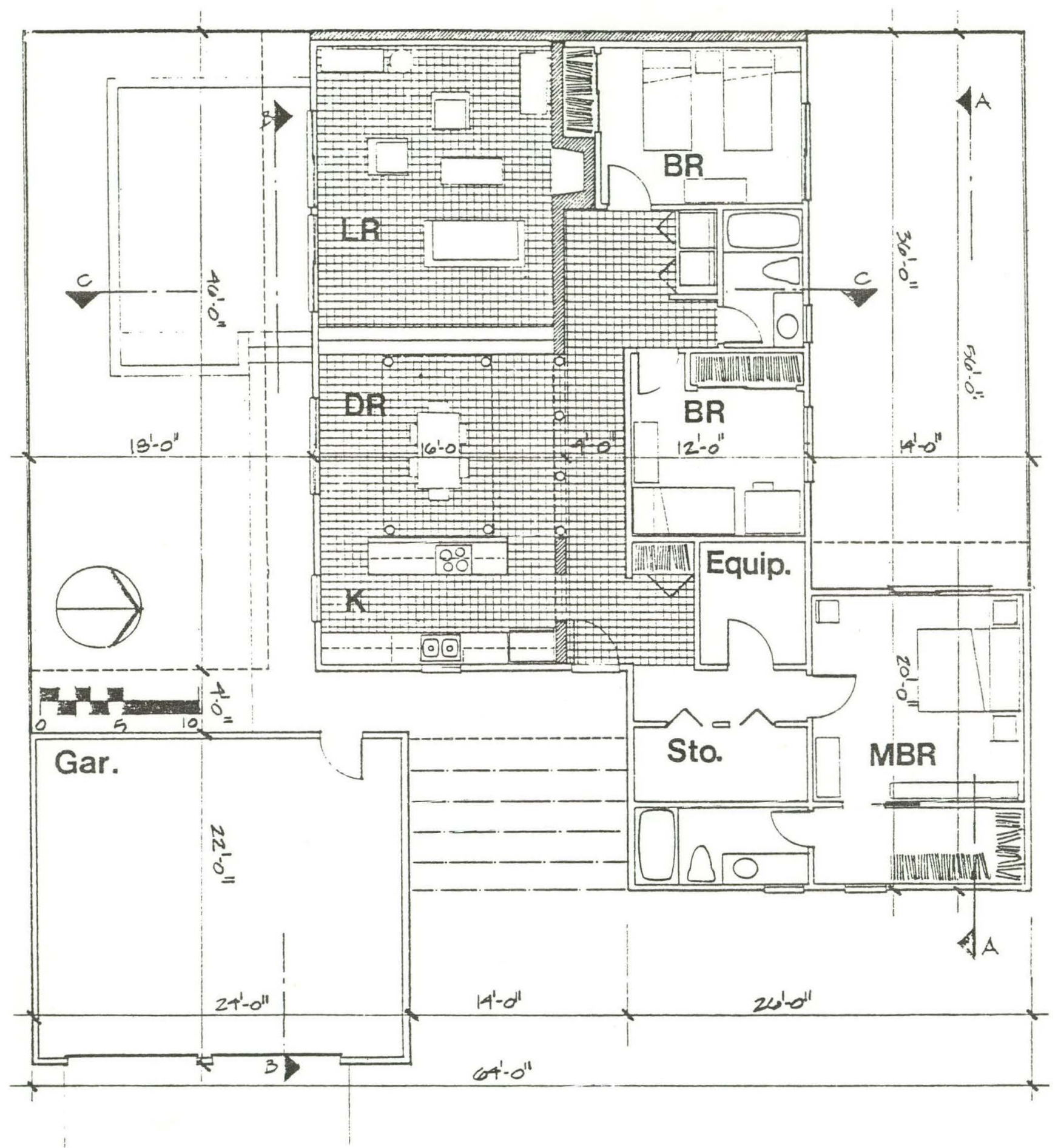

\begin{tabular}{|c|c|c|}
\hline 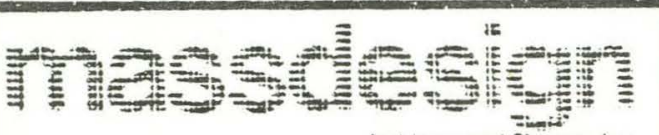 & $\begin{array}{l}\text { Job Na OS20 } \\
\text { Job Mam S. N. RES } \\
\text { G.E. PRCE DIVYSION }\end{array}$ & \multirow{3}{*}{ Sheet No. } \\
\hline \multirow{2}{*}{ 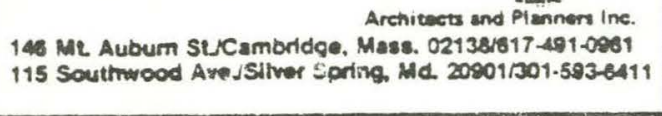 } & 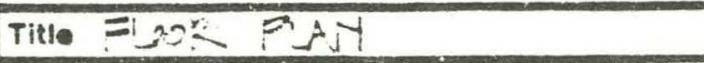 & \\
\hline & Dato $D E C, 1780$ & \\
\hline
\end{tabular}

Figure 1-4. Floor Plan 


\subsubsection{ENERGY CONSERVATION FEATURES}

Since the design must be appropriate for areas with high cooling loads, a substantial amount of energy conservation has been used. In an area like Las Cruces, El Paso, and the maritime climates of Southern California, both heating and cooling loads are relatively low. Even so, studies show that high levels of energy conservation, if accomplished by using relatively standard and inexpensive components, are cost effective. For this reason, the level of energy conservation shown would apply to most southwestern climate locations.

Walls are $2 \times 6$ stud construction with R-19 insulation, additional insulation between headers, and open corner-post construction to allow corner insulation (See Figure 1-5.) Ceiling insulation is limited by the size of supporting members, since no attics are used in the design. Levels will vary from R-25 to R-30. Double-glazing will be used on south windows, with triple glazing on all other exposures. Night insulation is used on south glazing, although the R-factor is much lower in an area with mild winters. The exact $R$-factor depends on the actual product but varies between $R-2$ and $R-5$.

\subsubsection{PASSIVE SOLAR FEATURES}

Although the Southwest does include mountain areas with substantial heating loads, this design concentrates on the more common situation of a hot summer and moderate winter, characteristics of Phoenix. Computer studies with the GE thermal nodal building model showed that for a climate with 2500 heating degree days, the house design resulted in little net heating load between March and November for El Paso. It is important to pievcnt over heating of the space during these months. A $0.91 \mathrm{~m}(3 \mathrm{ft})$ overhang plus side-wall shading is therefore included in the design, providing the following shading coefficients on the south glazing:

$\begin{array}{lllll}\text { Apr/Aug } & =100 \% & \text { Jan/Nov } & =14 \% \\ \text { Mar/Sep } & =51 \% & \text { Dec } & = & 9 \% \\ \text { Feb/Oct } & =26 \%\end{array} \quad$.

On the west and east, only the master bedroom receives any substantial amount of solar gain. This wing is shaded by landscaping as well as by the courtyard walls. Flat roofs are covered with a heavy layer of white stone, providing both some reflectivity and mass to absorb solar gain for later re-release. (The extra 


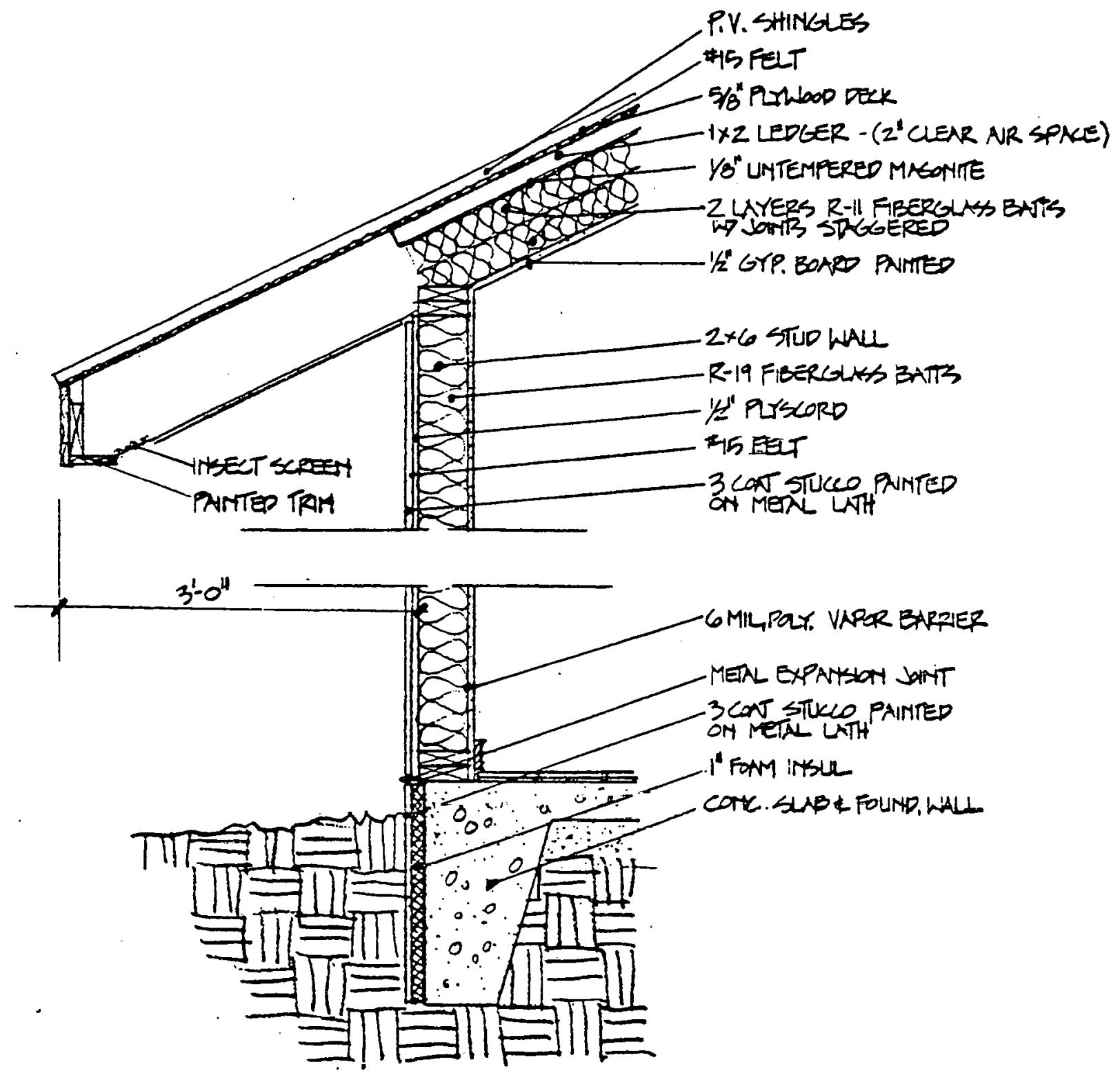

\begin{tabular}{|c|c|c|c|}
\hline \multirow{3}{*}{ 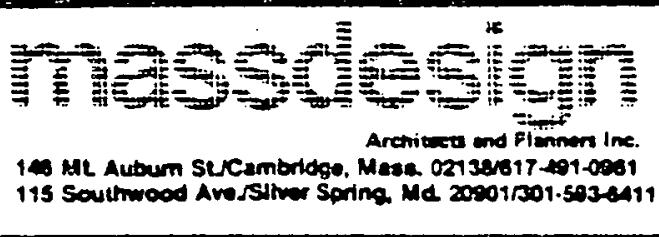 } & $\begin{array}{l}\text { Job Na. } 0528 \\
\text { Job Nam S.W. } \\
\text { G.E. SPAKE }\end{array}$ & & \multirow{3}{*}{ Shoet No. } \\
\hline & Titlo WAL SE & & \\
\hline & Scalo $3 / 4^{\circ}=1-0^{\prime \prime}$ & Dato DE, 10,1980 & \\
\hline
\end{tabular}

Figure 1-5. Wall Section with Insulation Details 
structure to support the heavier roof is needed to provide added insulation space.) A clear $5 \mathrm{~cm}$ (2 inches) vent space is provided under all roofs to encourage cooling ventilation at night, to dissipate the heat stored in the rocks.

Direct passive gain into the 3 living areas provides solar heating in the winter months. The slab-on-grade is $15.2 \mathrm{~cm}$ ( 6 inches) thick, and is covered with dark quarry tile set in grout in the living spaces. Again, quarry tile is a traditional material in the Southwest.

\section{1 .3 THERMAL SUBSYSTEM}

The space heating, cooling and domestic hot water requirements are provided by electrical energy. A block diagram and a list of components composing the thermal. subsystem are shown in Figure 1-6. All of the equipment is located in the equipment room shown in the floor plan of Figure 1-4. The subsystem consists of a 2-ton GE Weathertron heat pump for heating and cooling with an electric resistive heating coil as backup; an 82-gallon hot water tank, with a single immersion heater located in the upper section of the tank; and the General Electric Hot Water Bank (HWB) unit. The 82-gallon tank and single-immersion heater are

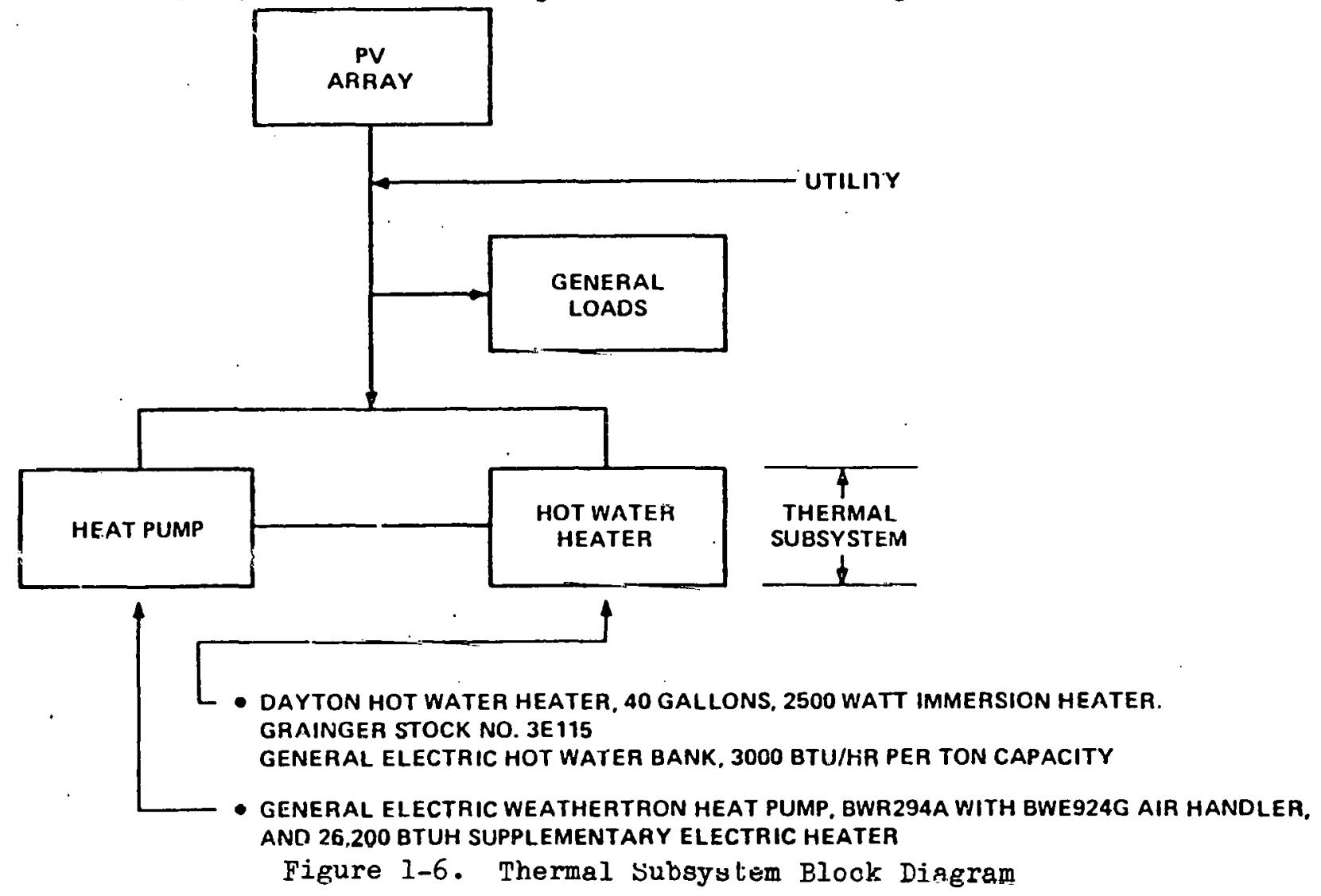


suggested for use with the HWB. Similar heat pump hot water heater units for water heating are available from Delta Energy Systems and Energy Utilization Systems; the units remove heat from the heat pump operation and transfer the heat to the water tank. Appendix D includes more details on the HWB and installations details are also available.

Figure 1-7 shows the HVAC layout for the house. Duct work is in two zones: zone 1 for the living spaces in the south; and zone 2 for the bedrooms and baths on the north. Duct work runs under the floor, with high and low returns located near the center of the house. Because of the number of control modes, a small microprocessor is specified. This device senses the temperatures in each zone and operates the central system and the transfer fans as desired. It also provides night setback and operates motorized insulating draperies (if the owner opted for these). Such a device is available now for around $\$ 500$ and should be commonplace by 1986 .

Nighttime ventilation is accomplished by thermosyphoning in the design, using north-facing clerestories under the cathedral ceiling of the living room. The owner could replace one of these windows with an exhaust fan. A fan is not included in the design because of questions as to whether the electric energy used yields an adequate payback. Even in New England, where cool nights are less common than in the southwest, thermosyphoning is a successful cooling strategy in passive houses.

Quiet transfer fans above each bedroom door operate to blow air from the gallery into the bedrooms during periods of winter time solar gain, when the living spaces will be warmer than the bedrooms. All thermal system operating modes are summarized in Figure 1-8.

\subsection{HOUSE ENERGY AUDIT}

The PV array is sized to meet a minimum of $50 \%$ of the total electrical load requirements of the house. The house load requirements are based on the results of previous studies and a thermal model for the space-conditioning thermal requirements. 

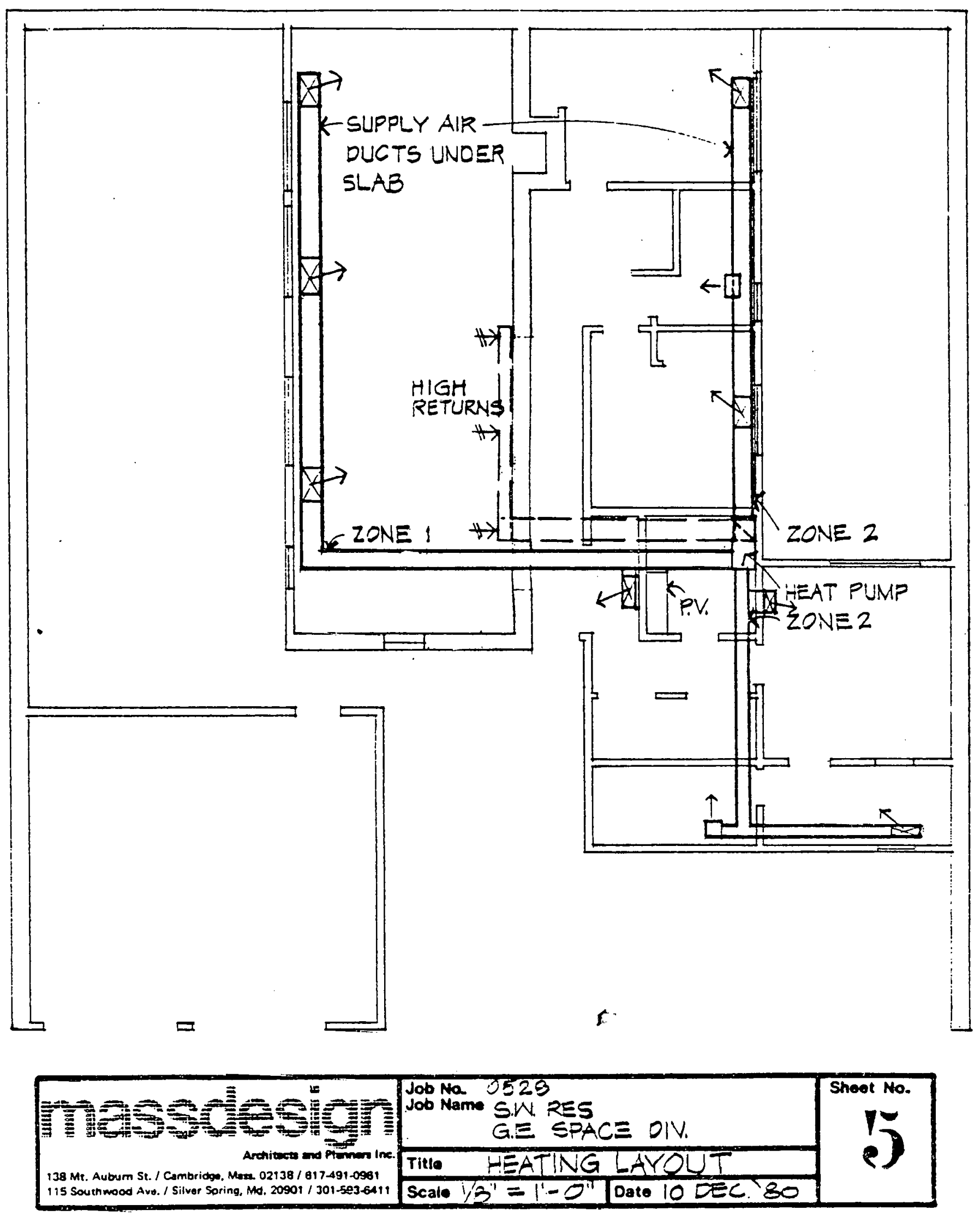

Figure 1-7. Duct Layout in Residence 


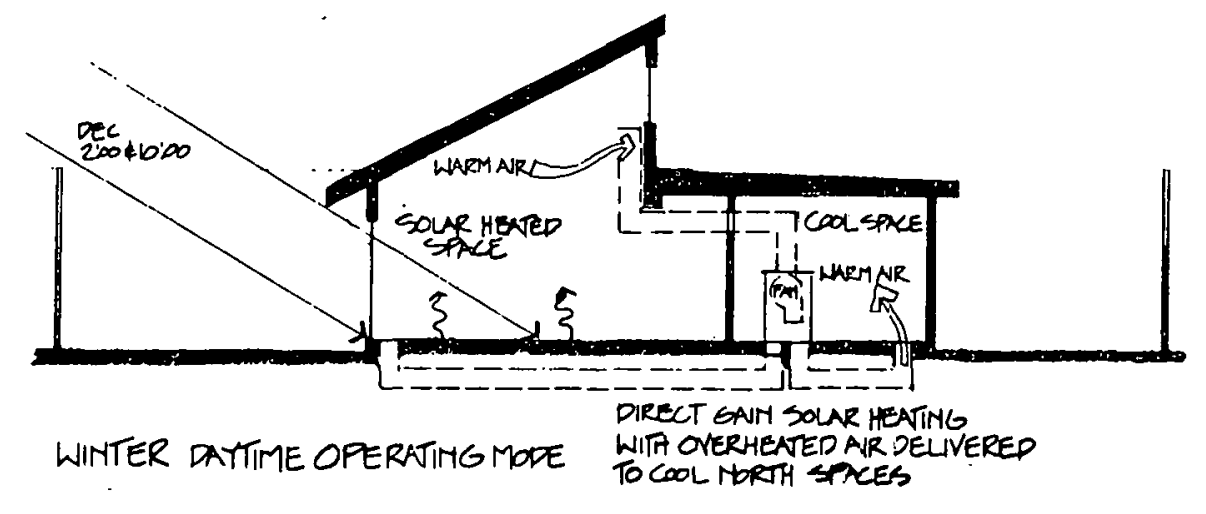

WINTER
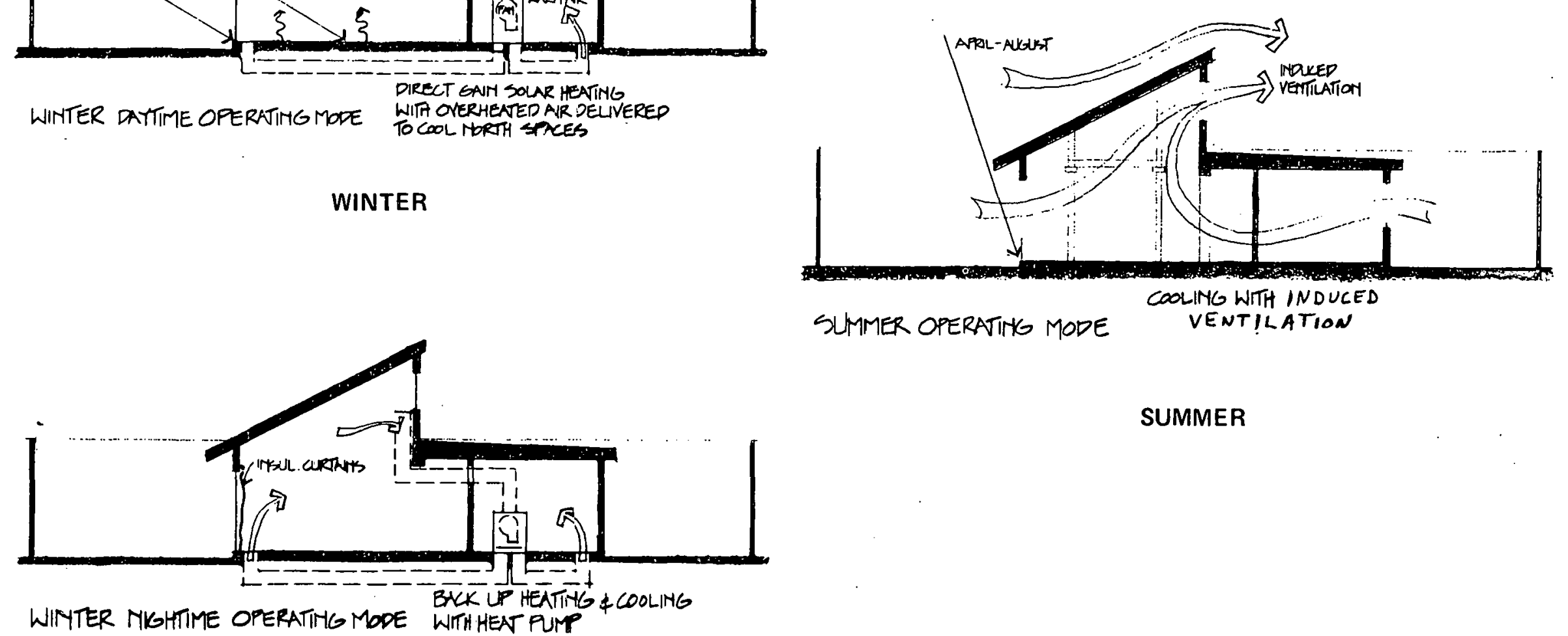

SUMMER

Figure 1-8. Thermal System Operating Mode 


\subsubsection{HEATING AND COOLING LOADS}

Space heating and cooling loads for the residence were computed on an hourly basis utilizing General Electric's Building Thermal Transient Load (BTTL) program. Program inputs included hourly weather and insolation data, building usage schedules, and a thermal model of the house. The thermal model was developed from the architectural plans and analytically represented the significant heat flow paths, thermal capacitances, and heat generating elements of the house. The model assumed two thermostatically independent zones: one, the living area; the other, the bedroom.area. In winter, the living area thermostat was set at $20^{\circ} \mathrm{C}$ during the day and at $17.2^{\circ} \mathrm{C}$ at night; while the bedroom thermostat was maintained at $17.2^{\circ} \mathrm{C}$ day and night. During the summer, the living and bedroom area thermostats were set at $25.6^{\circ} \mathrm{C}$ day and night.

The house was assumed to be occupied by a four-member family. The internal sensible and latent heat generated by occupants, lighting, cooking and miscellaneous appliances was derived from the hourly profiles of electrical loads and cooking loads.

The building loads were calculated on an hourly basis using El Paso Typical Meteorological Year (TMY) data, which compare closely with the data for Las Cruces. The predicted space conditioning loads which resulted from the analysis are summarized on a monthly basis in Table 1-1. These loads reflect a conservation strategy for utilizing outdoor air to satisfy cooling loads during the heating season (November through April); and during the cooling season whenever the ambient temperature is $5^{\circ}$ or more below the house cooling set point of $25.6^{\circ} \mathrm{C}$.

These space-conditioning requirements are translated into electrical load requirements through a heat pump simulation model.

A commercially available electrically driven heat pump is used to supply the space heating and cooling loads, and has been sized by conventional ASHRAE methods specifically for the photovoltaic residence design. The nominal rated capacity of the heat pump is 2 tons with an air flow of $800 \mathrm{cfm}$. The capacity and 
Table 1-1. Single-Family Monthly Load Profiles

Site
Location

Month

Janua ry

February

March

April

May

June

July

August

September

October

November

December

Total
El Paso

(kWh)

\begin{tabular}{cr} 
Cooling & Heating \\
0 & 894 \\
0 & 426 \\
0 & 258 \\
0 & 46 \\
779 & 5 \\
1392 & 0 \\
1520 & 0 \\
1294 & 0 \\
1051 & 0 \\
502 & 43 \\
0 & 183 \\
0 & 585 \\
\hline
\end{tabular}

$6538 \quad 2440$

coefficient of performance are shown as a function of ambient temperature in Figure 1-9. These characteristica are modeled in the system performance computer program along with features associated with the defrost cycle.

The electrical loads for the heat pump operation to meet the thermal requirements are also summarized monthly in Figure 1-9.

\subsubsection{DOMESTIC HOT WATER LOADS}

The domestic hot water (dhw) load profile is defined based on the results of previous General Electric studies (References 2 and 3 ). The load profile was developed independent of region and then adjustment factors, reflecting the local ground temperature, are used to adjust the load levels. Figure $1-10$ shows the hourly dhw load profile. The El Paso area adjustment factor is 0.96 . Thus, the daily dhw loads are $11.5 \mathrm{kWh} /$ day or $4220 \mathrm{kWh}$ annually. 


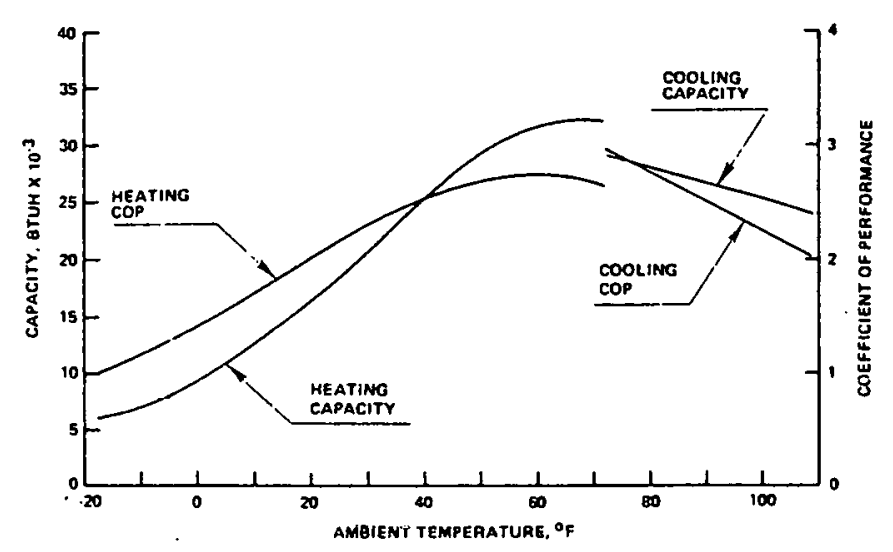

CHARACTERISTICS

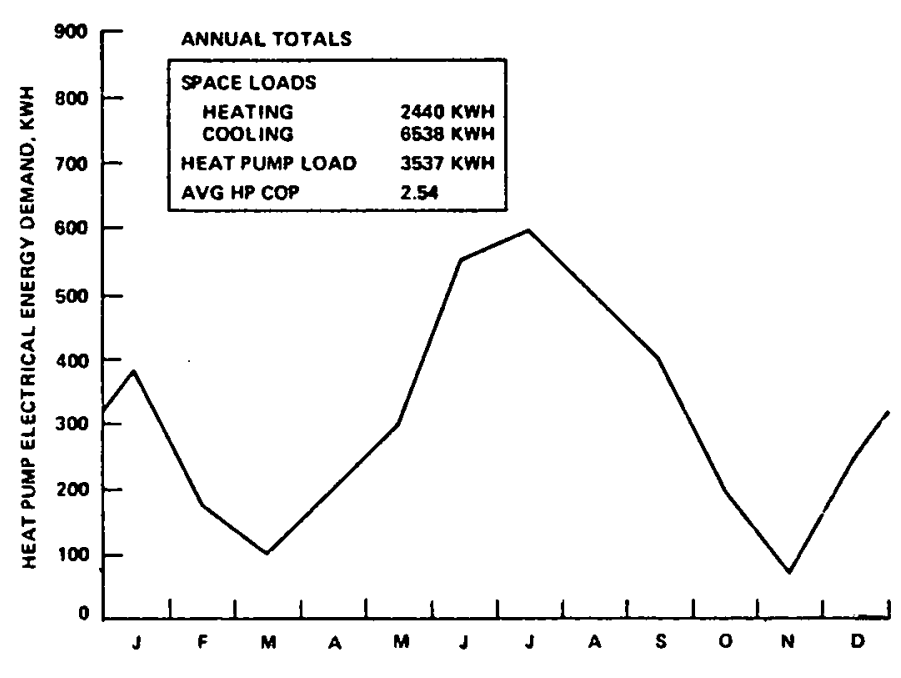

ELECTRICAL REQUIREMENTS

Figure 1-9. Heat Pump Characteristics and Space-Conditioning Loads

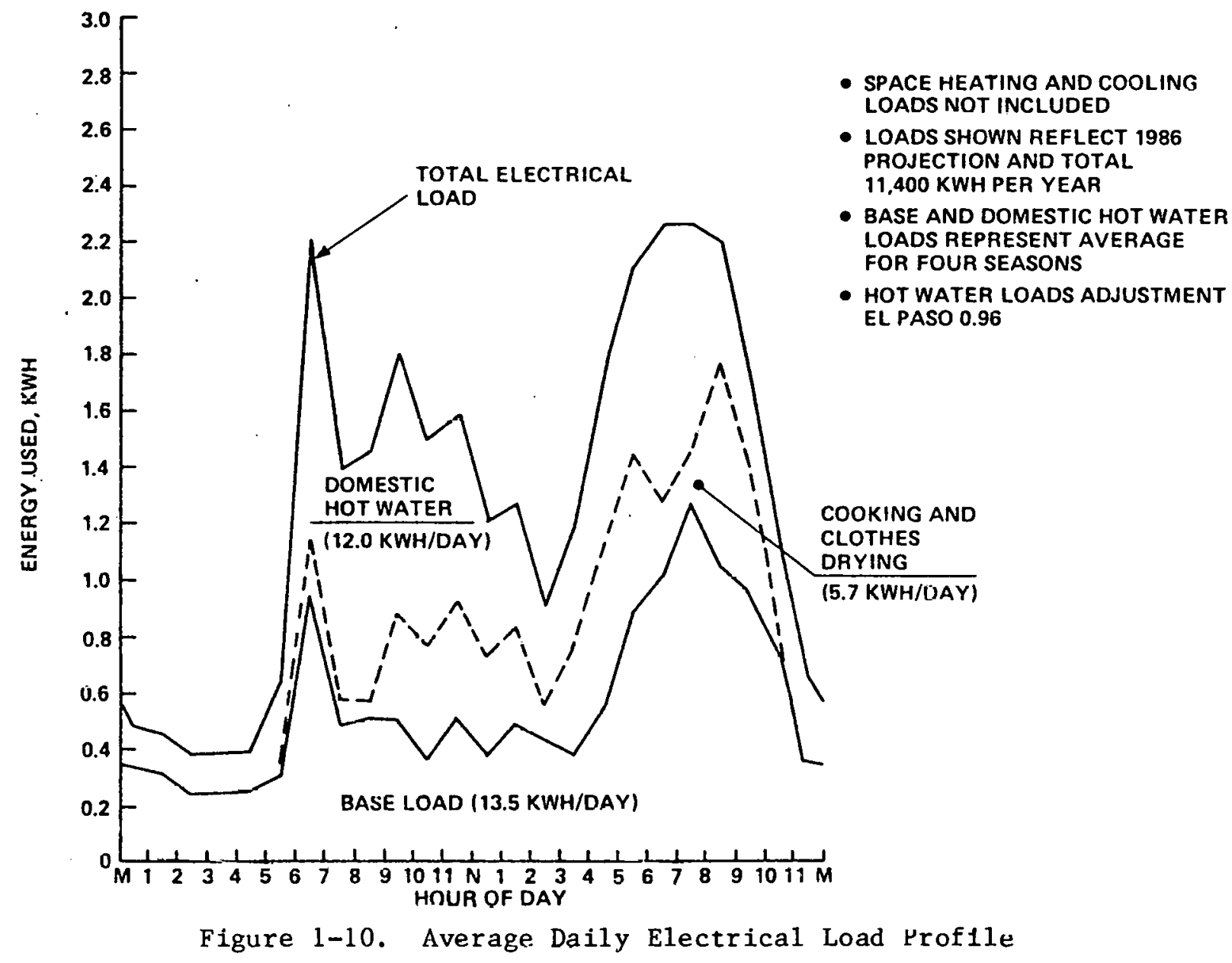


The residence design uses a Hot Water Bank heater to supplement the domestic hot water heating requirements. The Hot Water Bank is a water heating device consisting of a pump, a seasonal change over valve, heat exchanger, piping, and controls. It extracts superheat from the compressor discharge gas of a central air conditioner or heat pump and transfers this "waste" energy to the domestic hot water tank (see Figure 1-11).

During the cooling season the heat removed by the Hot Water Bank does not adversely affect the operation of the heat pump, but actually improves the heat pump efficiency by providing additional area for condensation of the hot refrigerant gas exhausting from the compressor. This improved heat pump efficiency is not accounted for in the present analysis.

During the heating season the heat removed by the Hot Water Bank would normally be used for space heating and, therefore, must be replenished by longer heat pump operating cycles. In this operating mode, the heat pump is being used to supply some of the water demand. However, the overall effect of the Hot Water Bank on

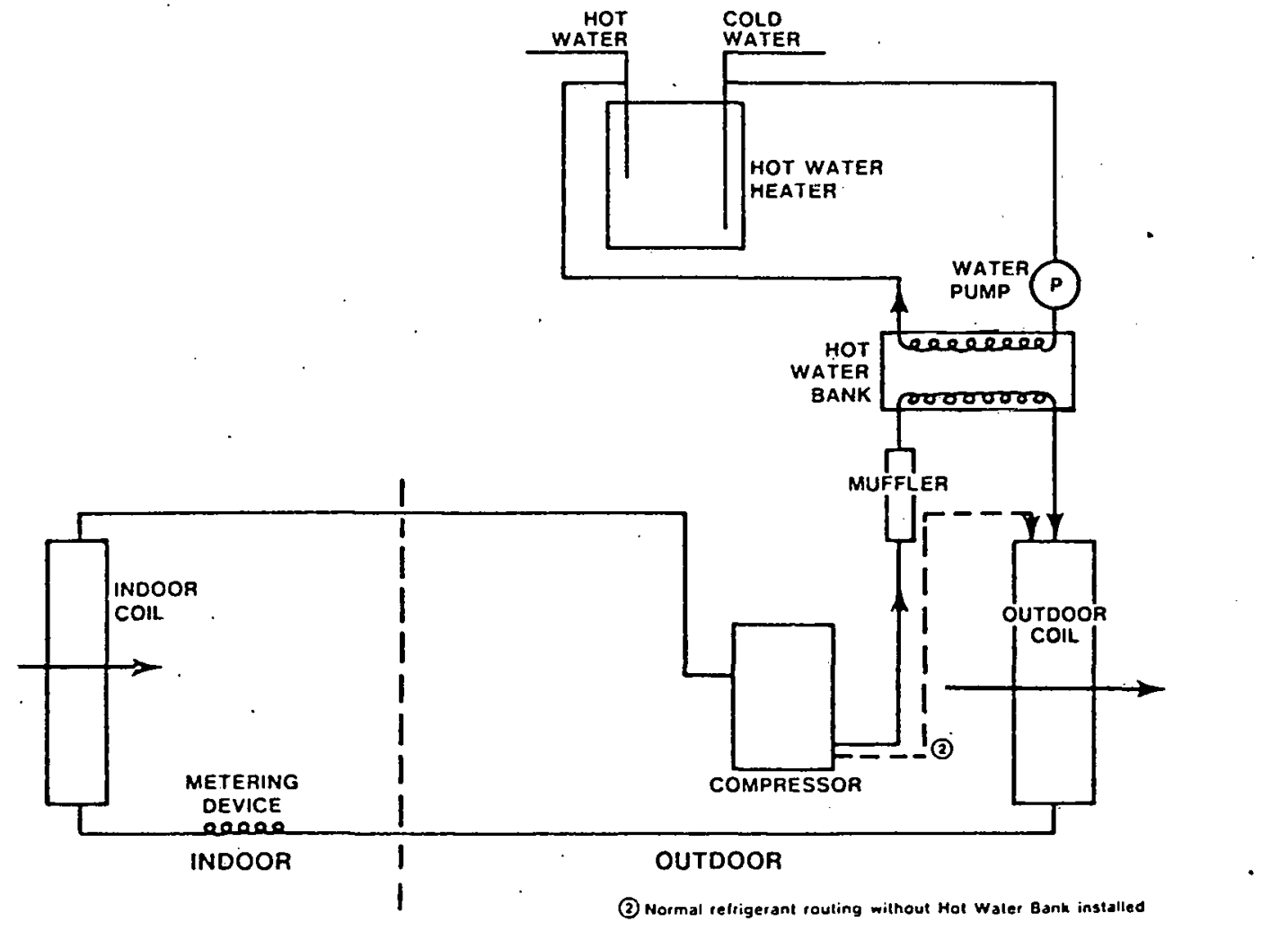

Figure 1-11. Hot Water Bank Schematic 
total electrical energy demand is beneficial since the heat pump COP is greater than that of the resistance heaters normally used to heat the water in the hot water tank. This effect is accounted for by the system analysis model.

The temperature in the hot water tank fluctuates hourly up to a maximum of $65.6^{\circ} \mathrm{C}$, with heat input from the heat pump and heat output to the load and losses. The electrical load for hot water heating is reduced by the amount of heat which is actually delivered to the hot water load.

Figure 1-12 shows the monthly electrical load for heating water and for the heat pump, with and without the Hot Water Bank. Note that the Hot Water Bank savings improve with increased heat pump usage in the summer as reflected by the heat pump electrical load profile (lower curve). During the heating season the Hot Water Bank savings of $344 \mathrm{kWh}$ are achieved at the expense of a $130-\mathrm{kWh}$ increase in heat pump electrical load. On an annual basis the Hot Water Bank saves 1177 $\mathrm{kWh}$, or $28^{\circ}$ of the hot water load, while the heat pump electrical demand increased $130 \mathrm{kWh}$, thereby resulting in an overall reduction in total electrical
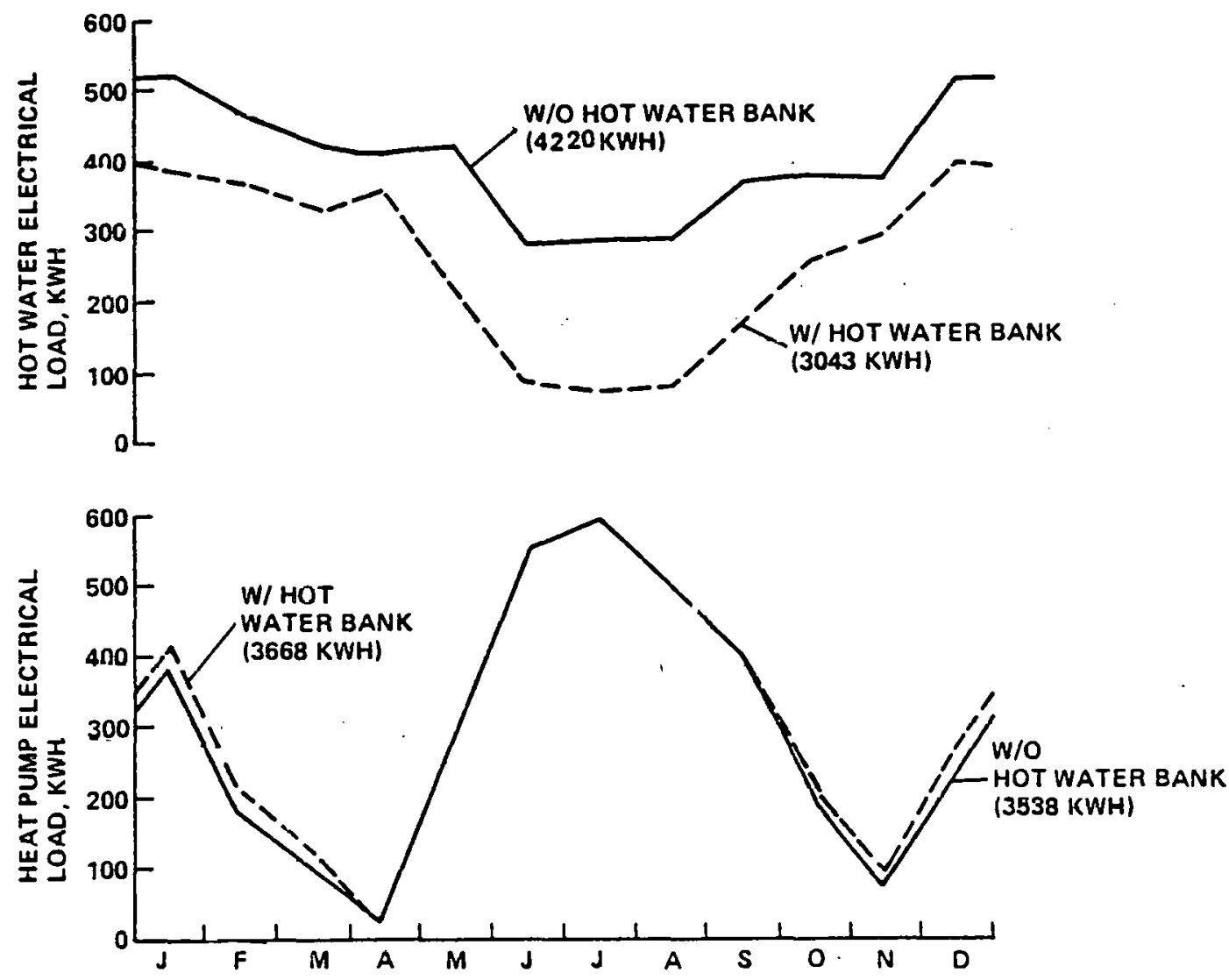

Figure 1-12. Effects of Hot Water Bank Utilization 
load of $1047 \mathrm{kWh}$. The Hot Water Bank provides an effective means of reducing the household electrical load for an installed cost of approximately $\$ 700$. Appendix D provides additional background information on the GE HWB.

\subsubsection{DIVERSIFIED ELECTRIC LOAD}

Average-day electric-demand profiles, also developed previously, are used for the analyses. These profiles are shown in Figure 1-10. The major components of the total load (cooking, drying, and baseload) are identified and quantified. The diversified load demand amounts to $19.2 \mathrm{kWh} /$ day or $6988 \mathrm{kWh}$ annually.

\subsubsection{ESTIMATES OF SOLAR CONTRIBUTIONS}

\subsubsection{Array Sizing}

Since the PV system output is proportional to the array size and the size of the array impacts the system cost, the effect of array sizing is best evaluated in terms of economic factors, such as levelized annual cost-to-benefit ratio. Previous system studies have shown that systems with utility feedback having sellback rates of $50 \%$ or more of the buy rate optimize at arrays covering the full roof. The requirements of the design, however, require that the array be sized to provide an annual output energy between 50 and 100 percent of the total estimated annual residential electrical load, but no larger than $74.4 \mathrm{~m}^{2}$ (800 $\left.f t^{2}\right)$

The array area was varied by maintaining 25 series modules along the roof slant height, yielding the same system operating voltage, and changing the number of parallel circuits. The resulting area variation is from $48 \mathrm{~m}^{2}$ to $73.3 \mathrm{~m}^{2}$ which is near the maximum allowable area. The results are shown in Figure 1-13 and indicate that a minimum of 15 parallel circuits supply nearly $100 \%$ of the load in the El Paso/Las Cruces area. The selection of a $25 \mathrm{~S}$ x $15 \mathrm{P}$ array would meet approximately $100 \%$ of the load for most Southwest locations. In addition, selection of $25 \mathrm{~S} \times 15 \mathrm{P}$ array is the same as installed in the NE RES and allows identical array performance characteristic comparison between the Northeast and Southwest regions. 


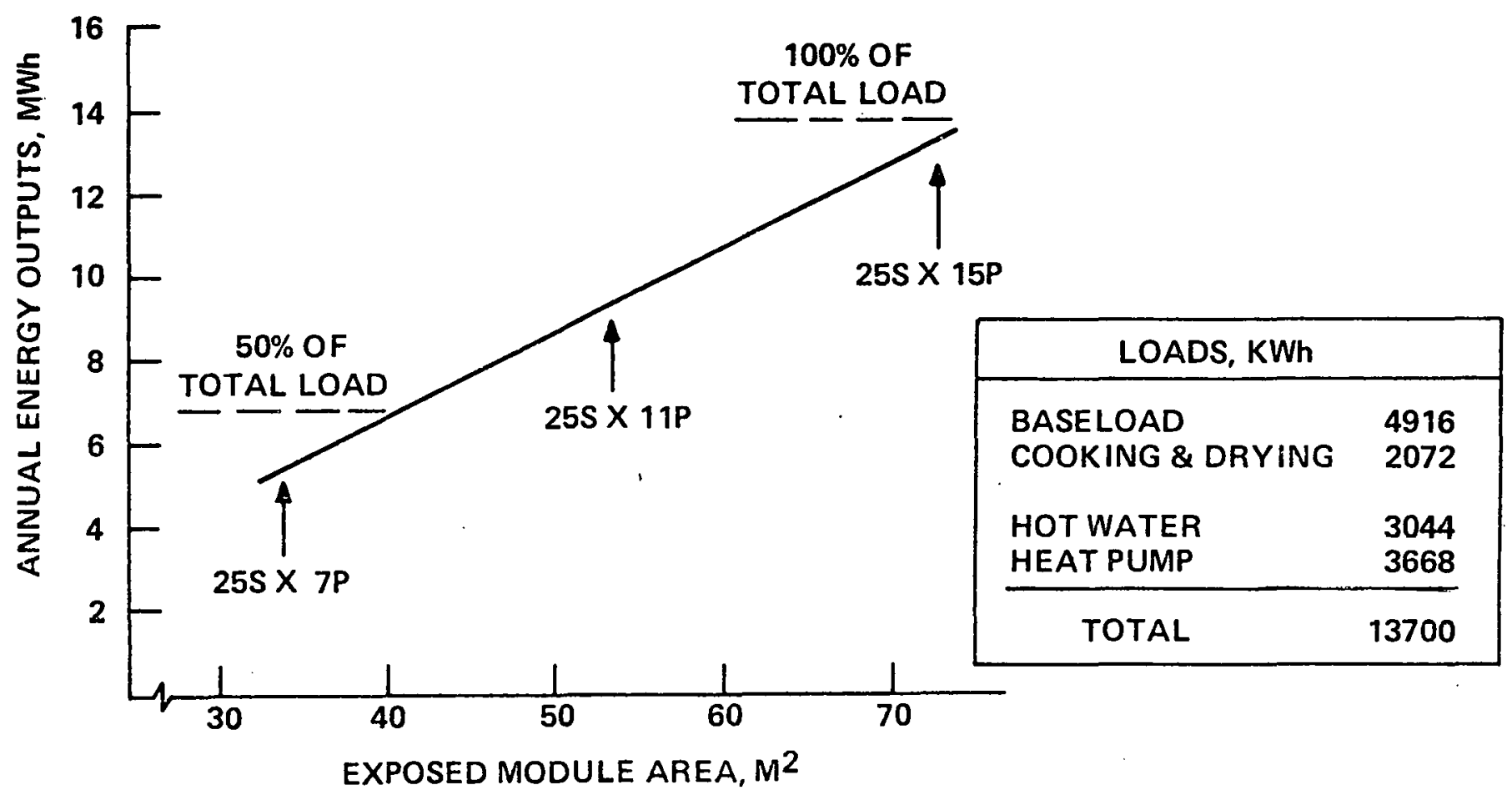

F1gure 1-13. Effect of Collector Area on Net System Output

\subsubsection{Array Tilt Sensitivity}

The sensitivity of collector tilt or roof slope angle to net system output was investigated with the results as shown in Figure 1-14. For this analysis, the array consisted of 25 series collectors by 15 paraliel circuits for a collector area of $73.3 \mathrm{~m}^{2}$. The results indicate that the system output is maximized with a roof slope of approximately $27^{\circ}$. This is consistent with trends established in earlier studies, i.e., the optimum tilt angle for PV arrays serving residential electric loads is about 10 degrees less than the latitude. The actual design slope was selected as $26.6^{\circ}$, which conforms to the use of standard framing techniques (6-inch vertical, 12-inch horizontal). It is also evident that only small differences in net system output occur over the tilt anyle range of 20 to $40^{\circ}$.

\subsubsection{Design Performance}

The monthly performance of the nominal design PV system is shown in Figure 1-15 for El Paso for the design array area of $73.3 \mathrm{~m}^{2}$. The monthly load, total PV 


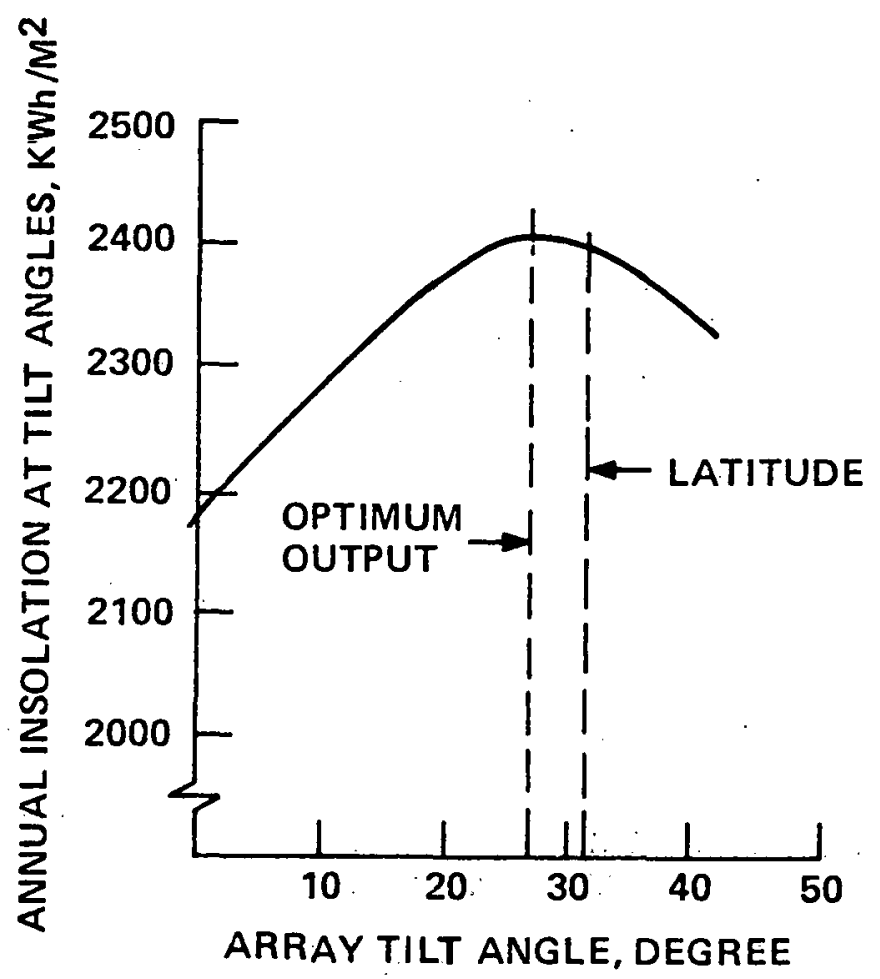

Figure 1-14. Array Tilt Angle Sensitivity

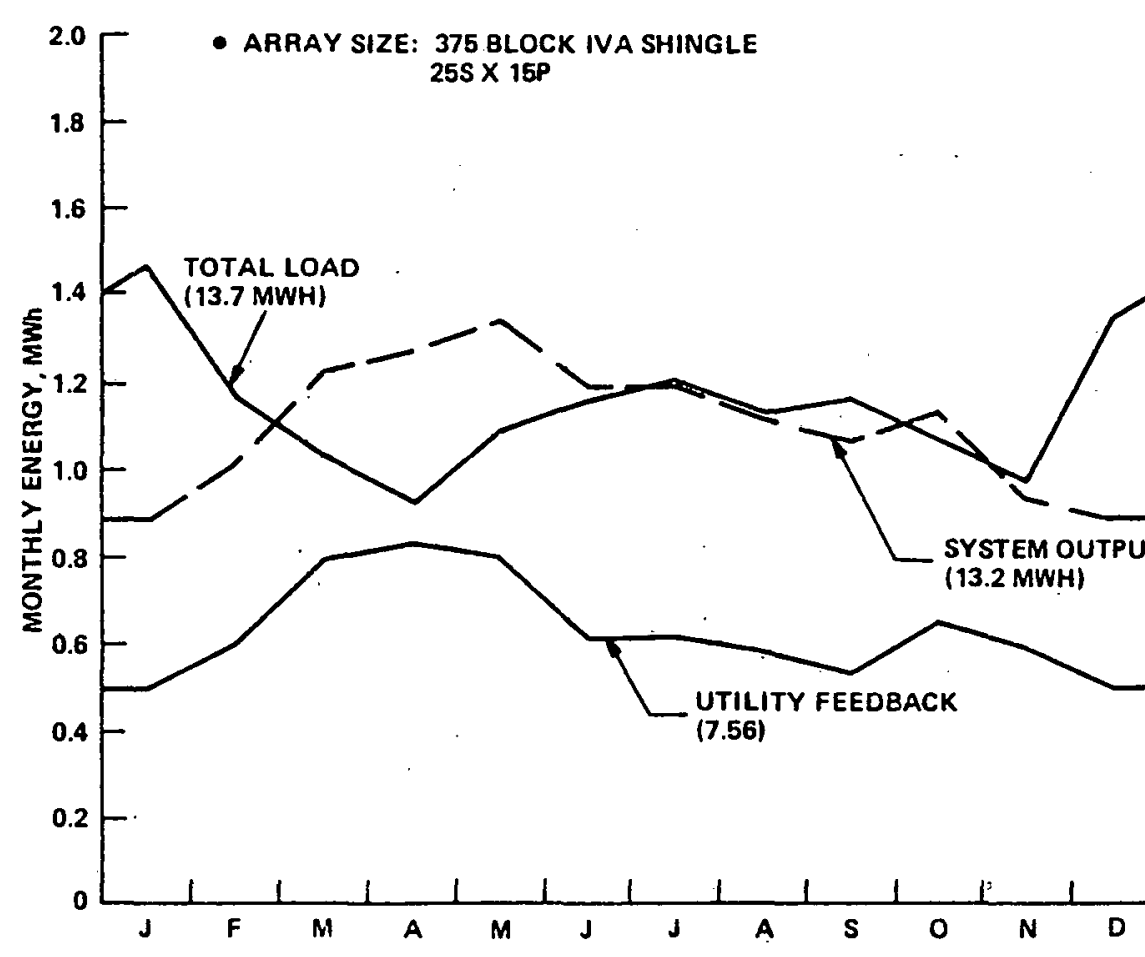

Figure 1-15. Monthly Performance Summary 
system output and energy feedback to the utility are shown. The system provides approximately 96\% of the total electrical load.* Table 1-2 summarizes the annual system performance. The solar array conversion efficiency is approximately $9.8 \%$ with less than $1 \%$ annual energy loss due to the series resistance losses in the shingle module bus strips, the termination bus bars, and the cabling between the bus bars and the inverter. The annual power Conversion Subsystem efficiency amounts to approximately $87 \%$ with the efficiency model assumed, resulting in the overall annual system efficiency of $7.5 \%$.

Table 1-2. Summary of System Performance for El Paso

\begin{tabular}{|cc|}
\hline Parameter & Value \\
\hline Total Exposed Module Area $\left(\mathrm{m}^{2}\right)$ & 73.3 \\
Annual DC Energy Input to Inverter (mWh) & 15126 \\
Annual AC Electrical Energy Output (mWh) & 13215 \\
Annual Insolation on Array Surface (kWh/m $\left.{ }^{2}\right)$ & 2391 \\
Overall System Efficiency $\frac{\text { System Output }}{\text { Insolation X Array Area }}$ & $7.5 \%$ \\
\hline
\end{tabular}

*The $96 \%$ figure is. a strictly algebraic result obtained by dividing annual PV production by annual residence load ( $x$ 100). One should not construe from this that all of the PV-produced energy is used in the residence. The actual amount used is a function of the instantaneous relationship of power produced to power consumed, integrated over the year. 
A design of a Prototype System, based upon the full-size photovoltaic residence design, and a Prototype System structure was developed. The design uses the identical roof section details of the full-size system; provides interior space to house balance-of-system equipment and load-duplicating equipment and instrumentation, and simulates the back surface temperature of the array to be encountered in the full-size residence. The complete set of working drawings for construction and installation is discussed in the following sections. Figure 2-1 shows a photograph of the completed Prototype System.

\subsection{STRUCTURAL DESIGN}

The design approach used for the prototype structure was to meet the requirements of the program with a minimum of structure cost but to provide a structure which had some visual amenities. The building is constructed on a slab-on-grade, with wood-frame walls adequately insulated (R-ll). Exterior finish is stucco, a common material in Las cruces which exhibits better lifetime under intense sun than wood. Figures 2-2 and 2-3 show the four elevations of the structure.

Windows are provided to light the interior and give the building a residential character. A double door is included on the north side for access and egress. A colored band, matching the contrasting wood trim, runs around the structure at the door and window head level to break up the large wall surfaces and enhance the residential character. Figure 2-3 also shows the interior floor plan of the structure, which has a total gross floor area of $62 \mathrm{~m}^{2}\left(672 \mathrm{ft}^{2}\right)$.

The electrical drop from the roof array is to the west, to match the drop in the residence design. The power conditioning equipment is at the west end of the room, along the north wall. The door is also on the north wall. Windows are located at the west wall, over the door, and to the east of the inside air handler. 


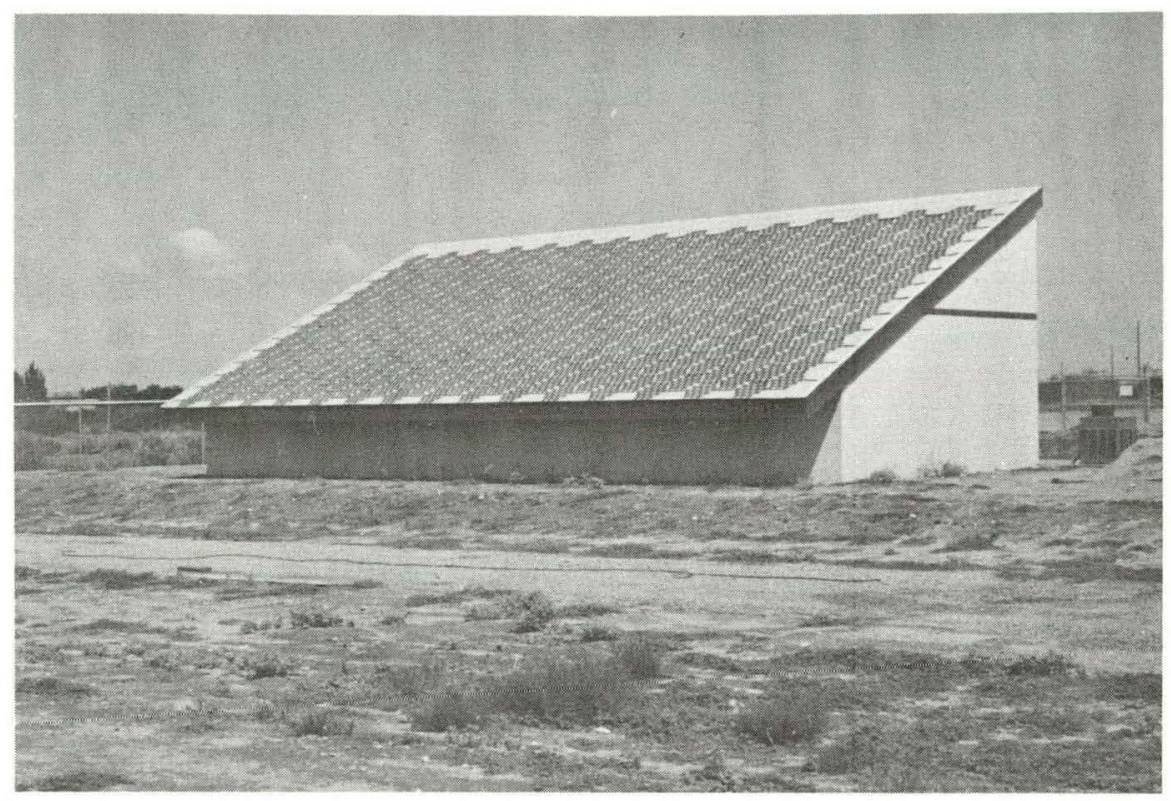

Figure 2-1. Structure Photograph

Figure 2-4 shows a section of the structure. The entire interior is finished in gypsum board and painted; about $2 / 3$ of the space has standing headroom. I'he floor slab is exposed smooth concrete, with an integral hardener.

The highest point of the roof is about $4.1 \mathrm{~m}(13.5 \mathrm{ft})$ from the ground, the lowest point is about $1.1 \mathrm{~m}(3.75 \mathrm{ft}$ ) from the ground, and the roof is about $5.9 \mathrm{~m}$ (19.4 ft) side to side.

The building roof is exactly like that of the proposed residence, having a cathedral ceiling with R-22 insulation, and a $5 \mathrm{~cm}$ (2 inches) air space under all portions of the array, to enhance natural ventilation. Details of the roof at the overhang and at the north wall are shown in Figure 2-5 with specifications for all materials. The figure also shows the rake details and interface with the slab. Window and contrasting paint strip attachment are shown in Figure 2-6.

Figure 2-7 shows the Prototype System site plan. 


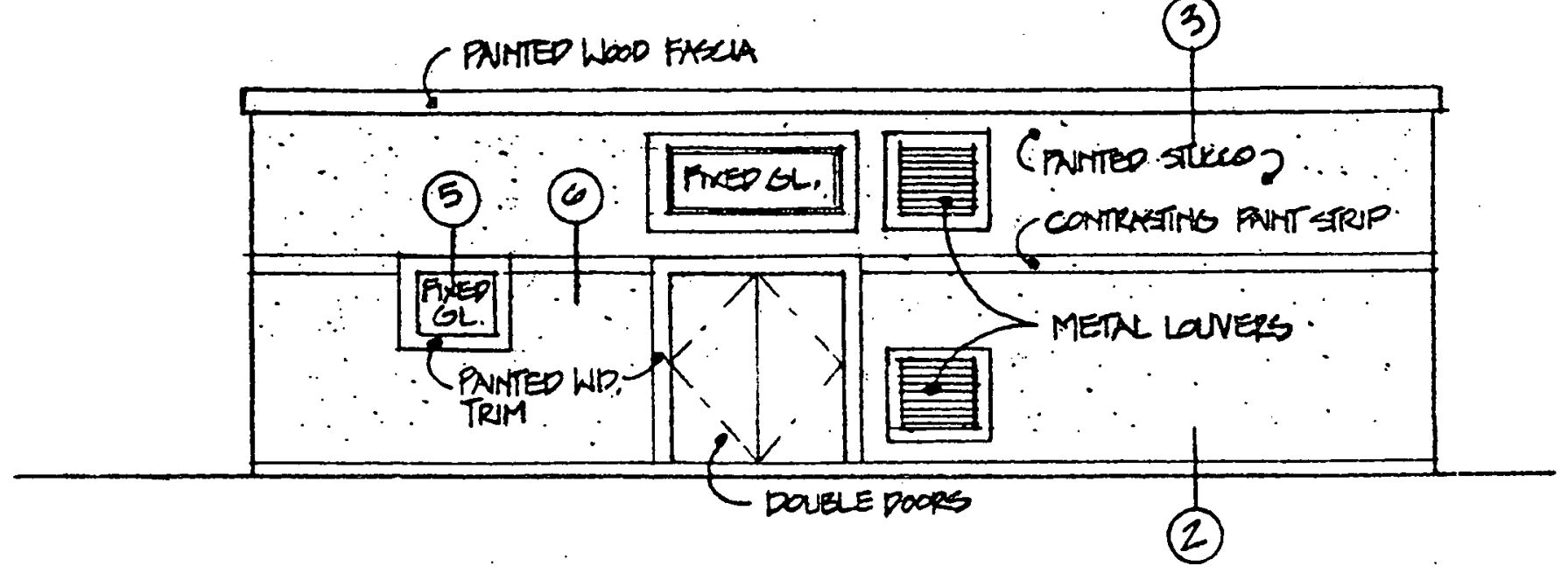

MORTH ELEVATON

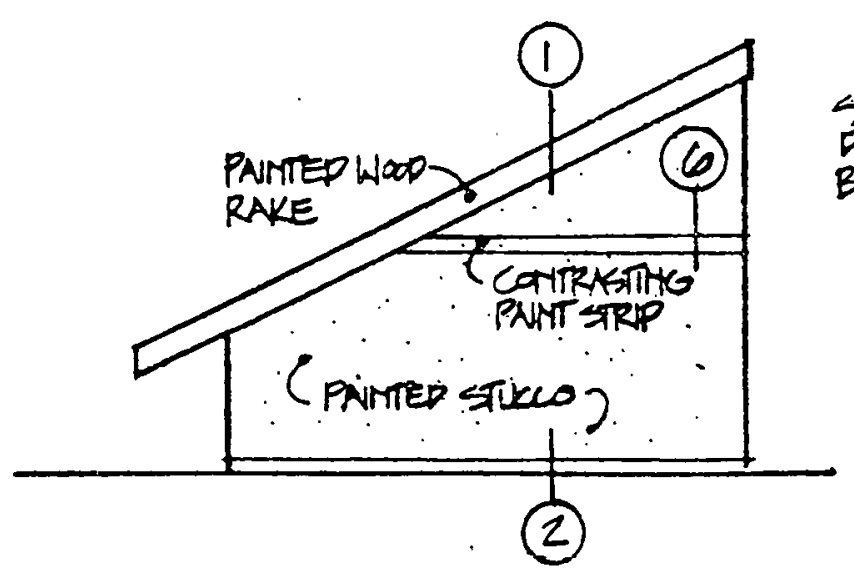

EAST ELEVATOM

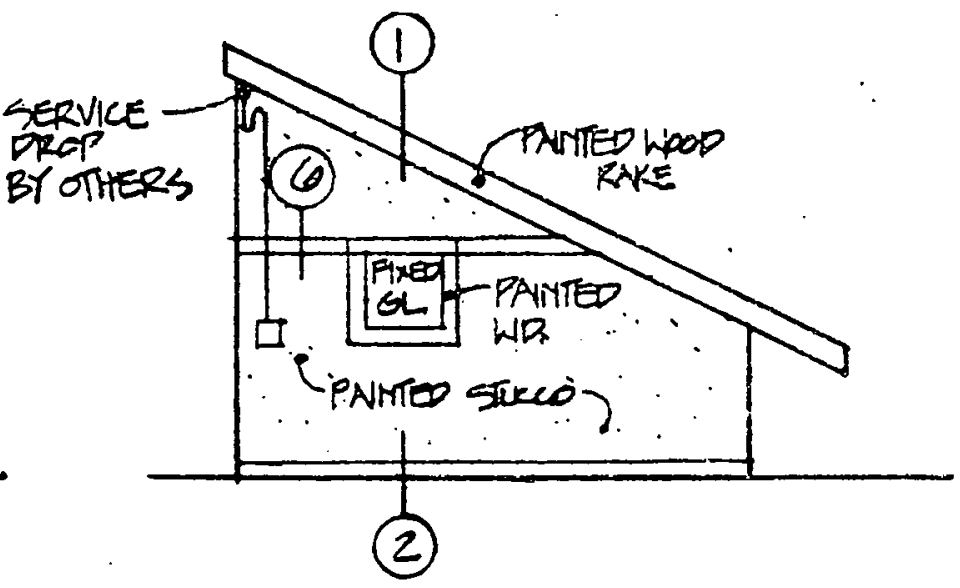

WEST ELEVATIOH

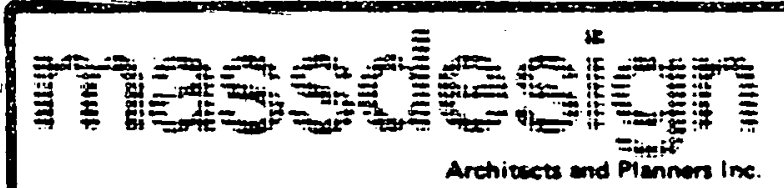

$148 \mathrm{ML}$ Aubum StCambridoe. Mask, 02139817-491-0981

115 Southwood Avejsituor Spartine. Md 20001/301.503-4111

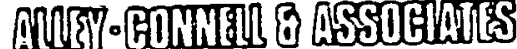

AREHITECTS rutinem
Job Ma 0528

Job Mam S.W. RES

G.E. SPNE DIVISTOY

Titio E.W.M. ELEVATIOTS

scale $1 / 8^{\prime \prime}=1^{\prime}-0^{12}$ Dato Dec 10 1980

305 north water

las enwose, rexs moxkeo 88001

irner tan $14+4$
Shoet No.

2

Thad

Figure 2-2. Elevations of the Prototype System Structure 

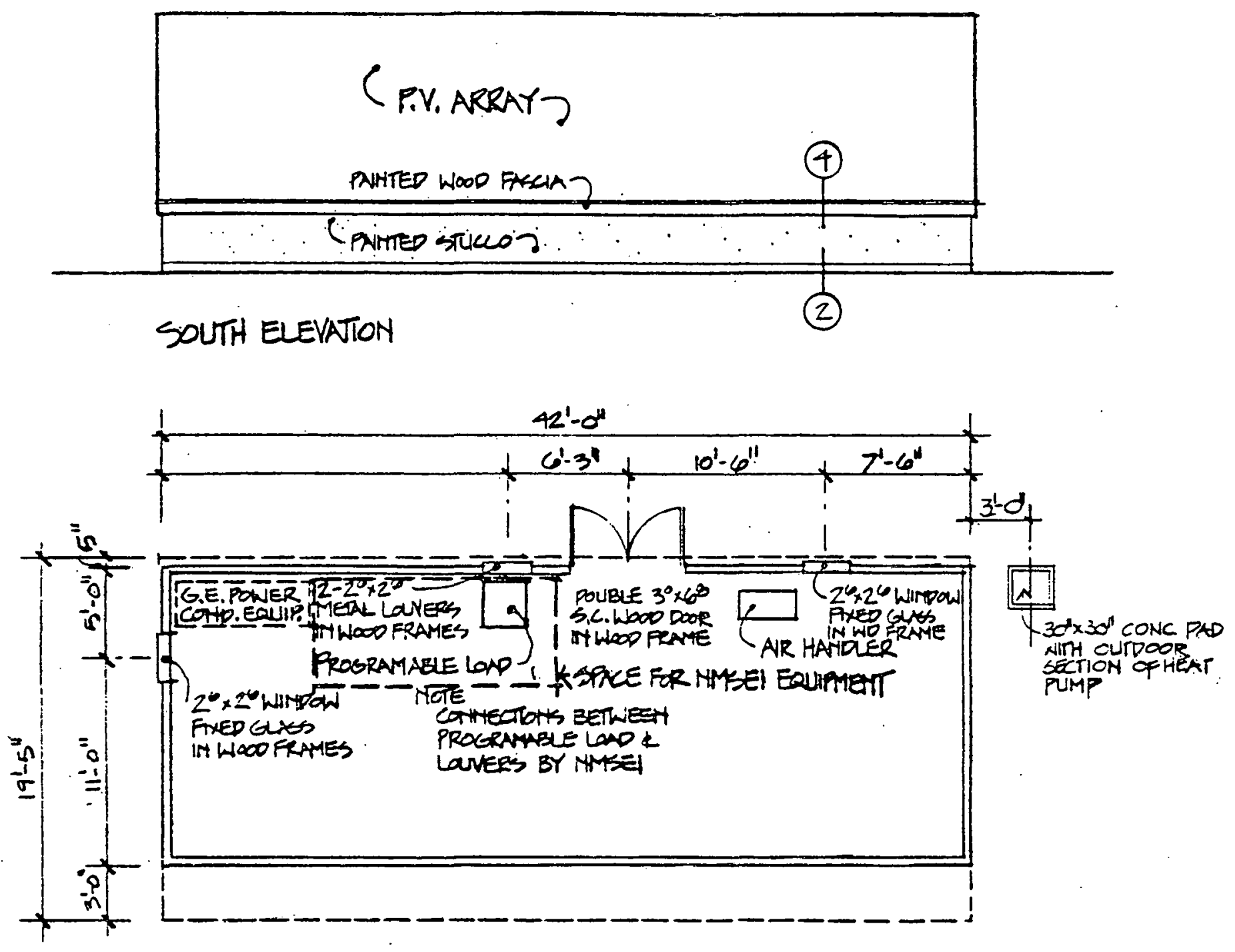

PAAY

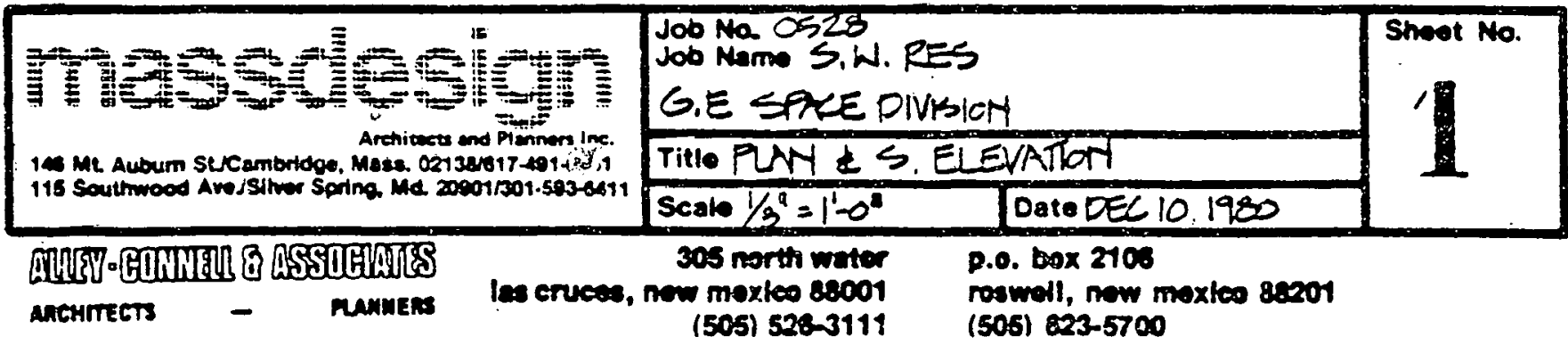

Figure 2-3. South Elevation and Floor Plan of the Prototype System Structure 


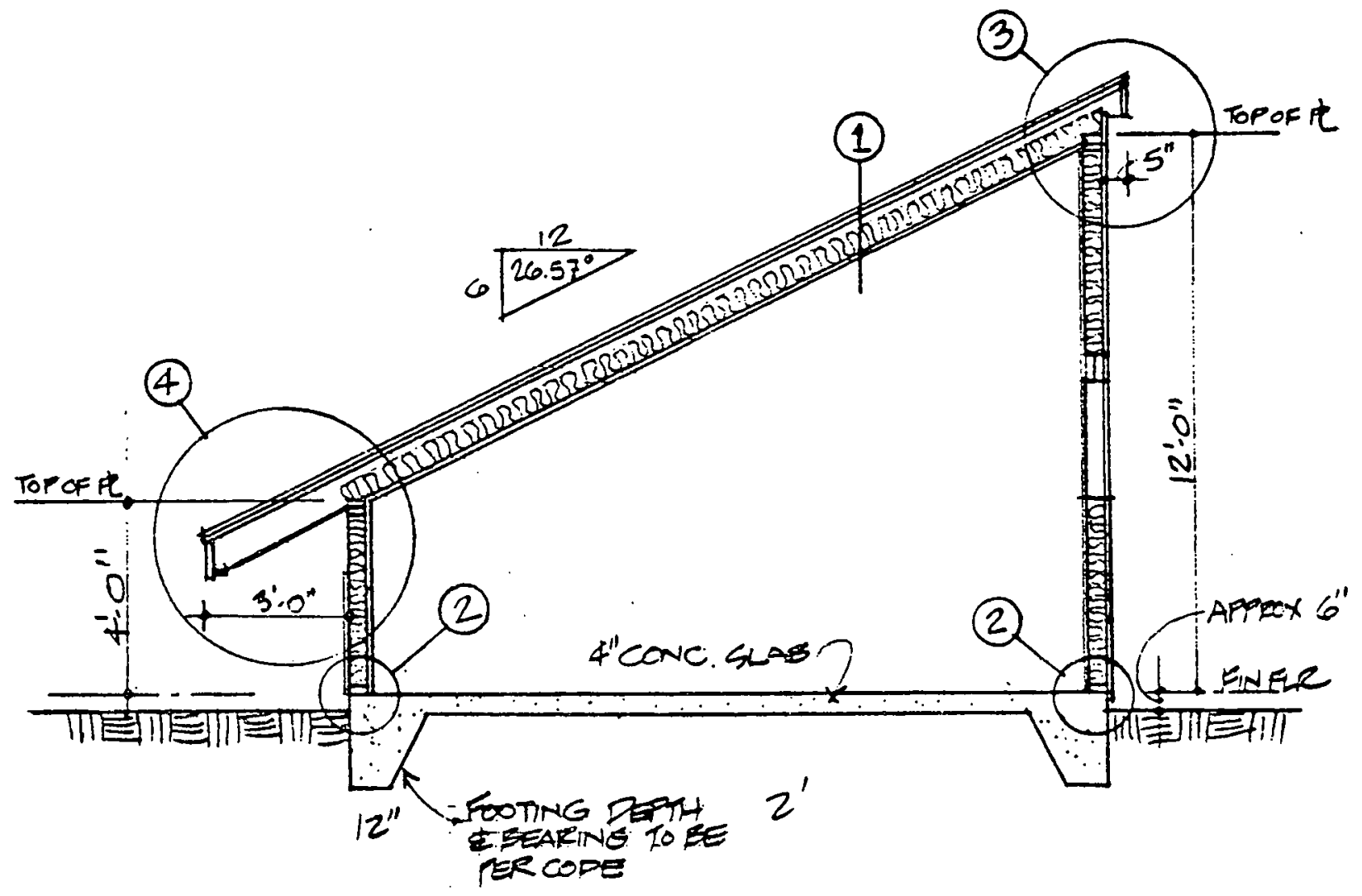

SECTION A.A

\begin{tabular}{|c|c|c|}
\hline 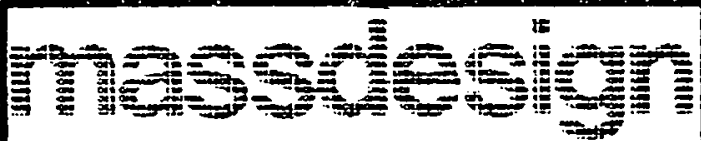 & $\begin{array}{l}\text { Job Na- OSZ8 } \\
\text { Job Name S.W. RES } \\
\text { GE SPACE DNISLN }\end{array}$ & Sheet No. \\
\hline Architues and Pitimner Ire. & Titlo SECTON A.A & \\
\hline 115 Southnood Ave. / Silver Spring. Mo. 20901 / 301-593-8411 & Scale $1 / \Omega^{n}=1 \cdot 0^{\prime \prime} \quad$ Date DEC 10,1980 & \\
\hline
\end{tabular}

Figure 2-4. Section of the Prototype Structure 

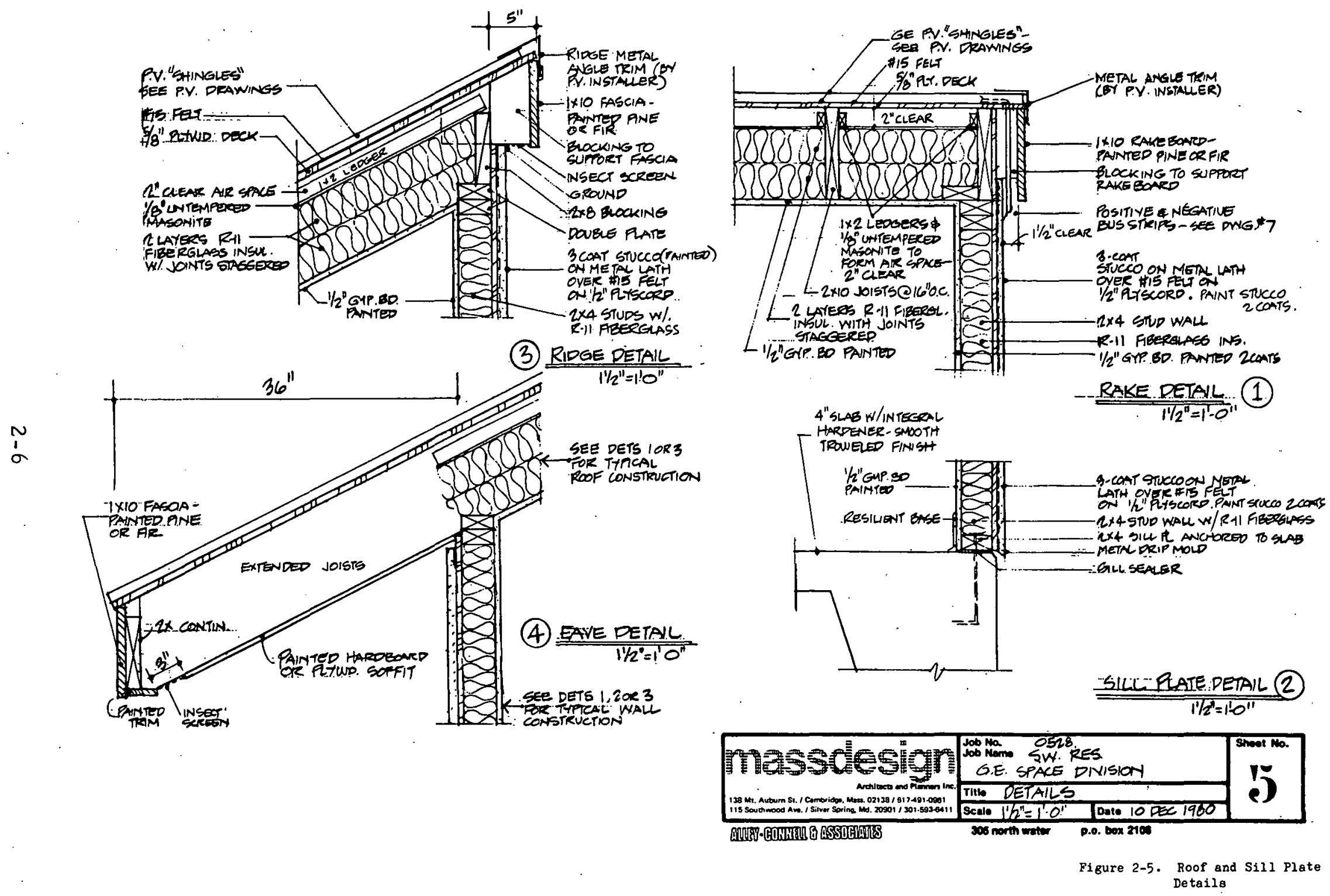

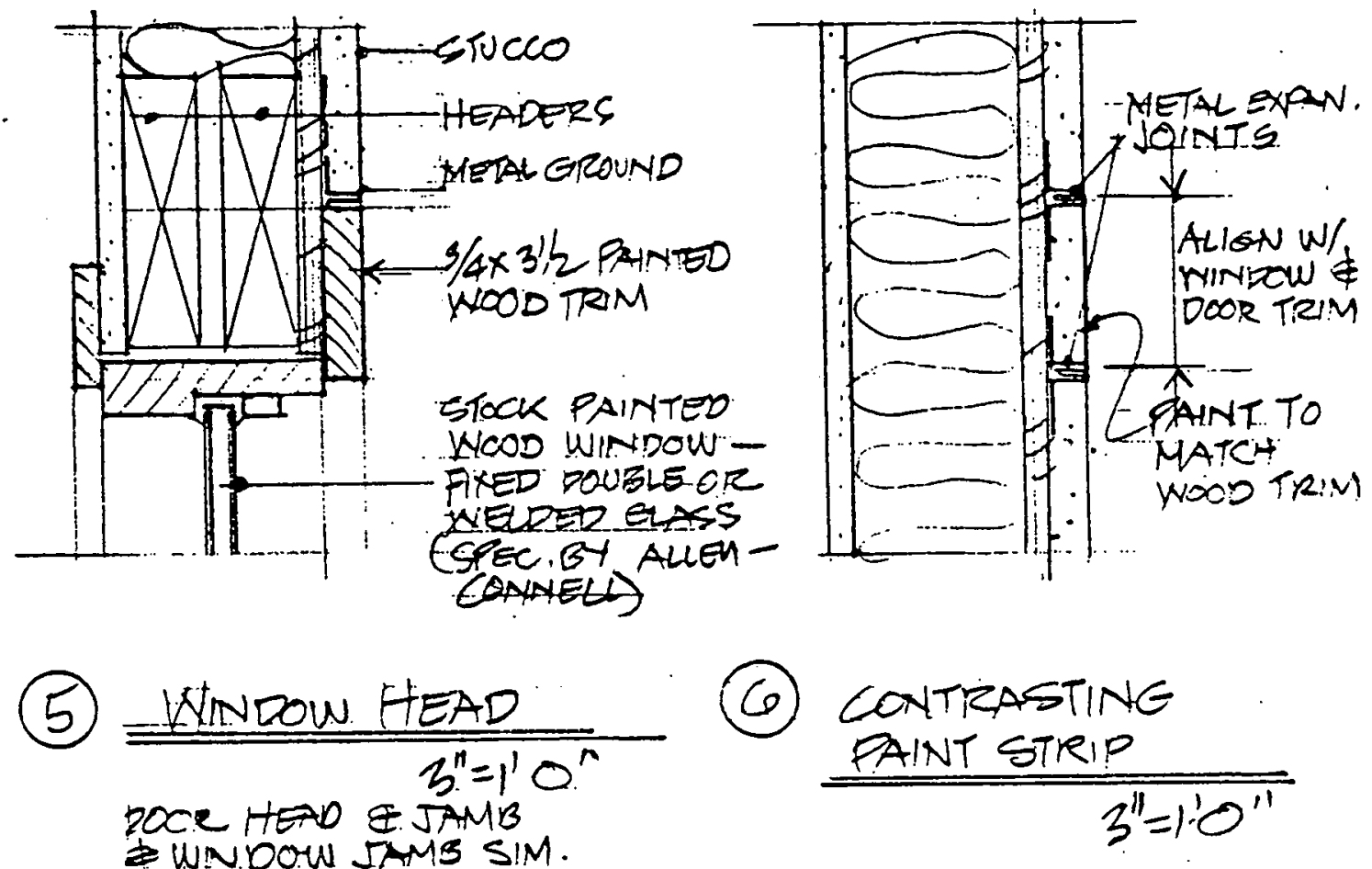
\& WNDOW JTMS SIM. Luver detalls SIM.

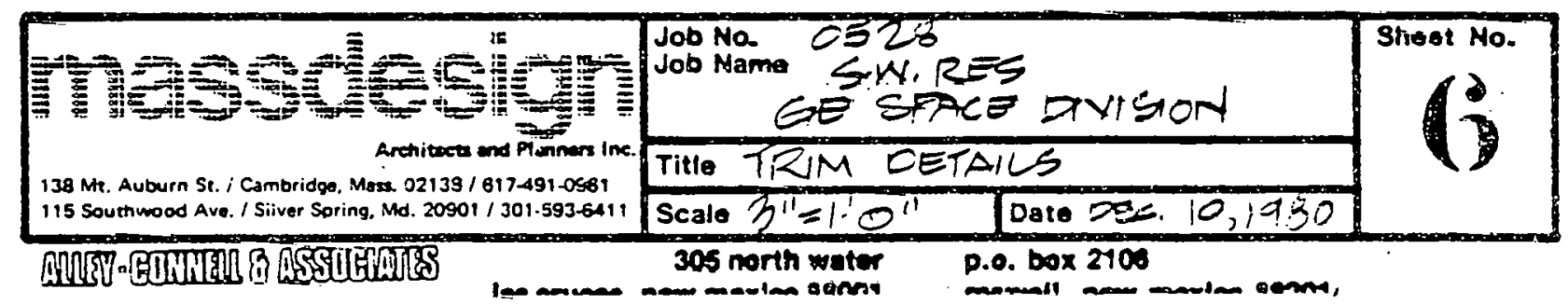

Figure 2-6. Window and Trim Details 


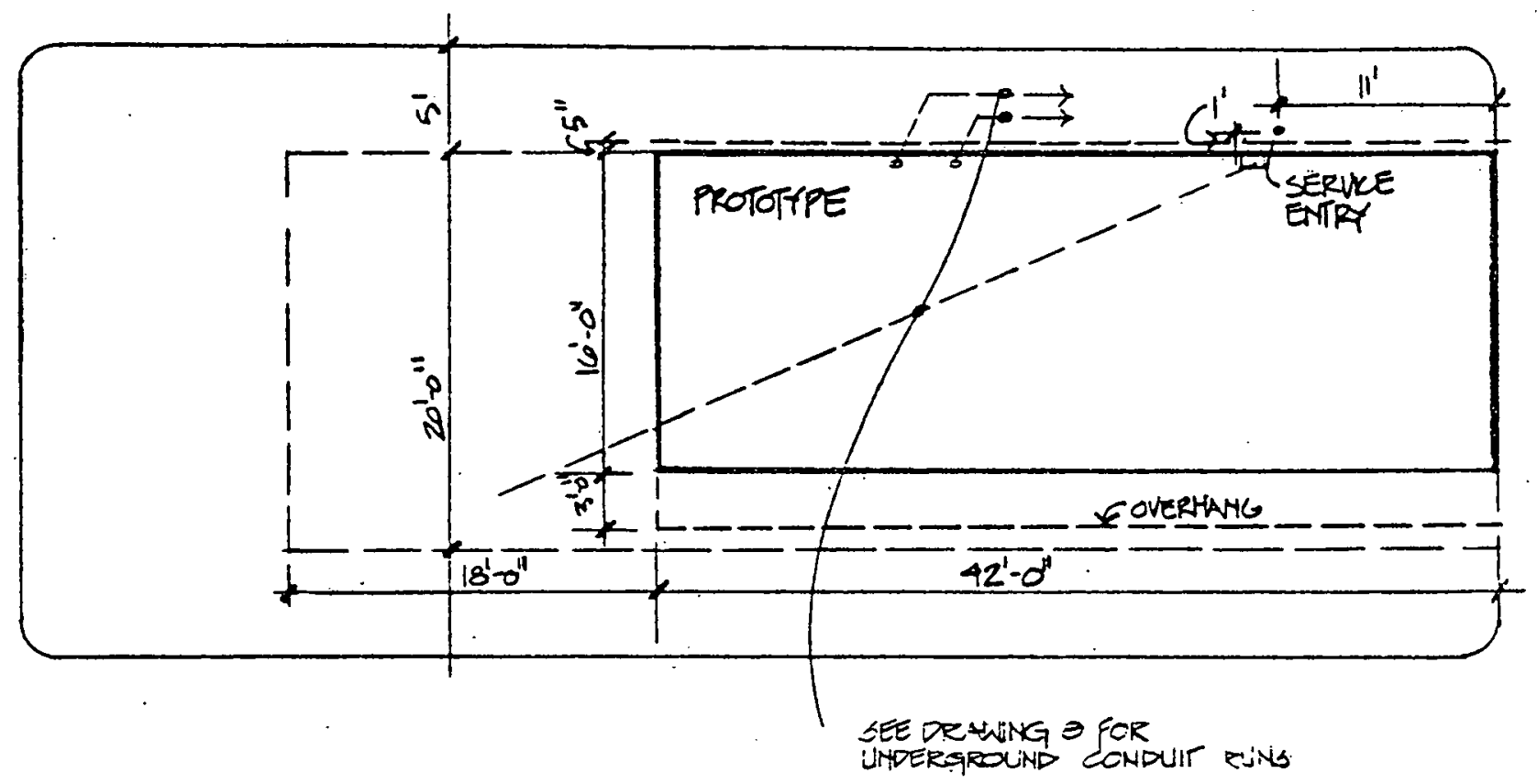

PRGTOTYPE SIE PLAY

$I^{\prime \prime}=10^{\prime} \cdot 0^{\prime \prime}$

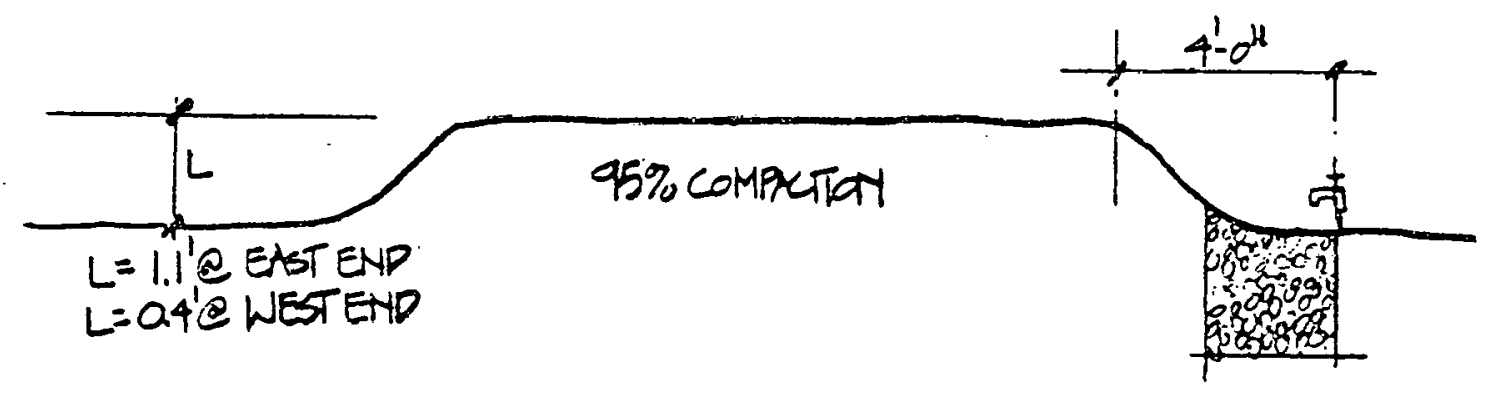

SITE SECTION

$1 / 8^{\prime \prime}=1^{\prime}-0^{\prime \prime}$

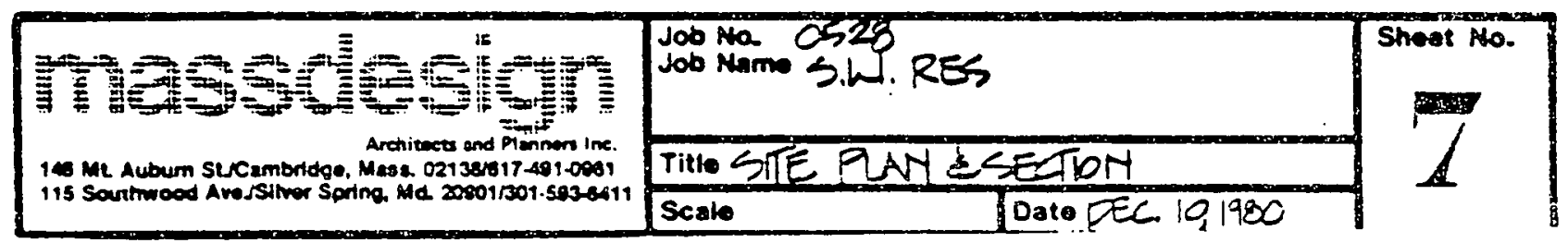

Figure 2-7. Prototype Site Flan 
A simple thermostatically controlled heating and cooling system has been designed to maintain the temperature inside the prototype at representative levels similar to the proposed residence. The simplest and most practical heating and cooling system for the building is a unitized air handler with an electric resistance coil, and a coil connected to an outdoor condenser or heat pump. Since the heat pump option is only slightly more expensive than the standard A/C option, it was selected to economize on energy.

The indoor unit is a GE WE-918-G-100-E vertical air handler w1th an AY-96-X-1411 resistance heater coil. An $A Y-61-X-632$ refrigeration line set connects the air handler to the BWB-918-A-100-A outdoor heat pump section, which is mounted on the gravel to the east of the building.

The air handler has an extension duct on the top which lifts the air above head height. It then discharges in three directions. This system provides thermal conditions for the cathedral ceiling and roof array similar to the full-size residence.

Lighting is supplied by four 8-foot, 2-tube fluorescent fixtures mounted to the sloped ceiling to provide good light on the electrical equipment. Several windows provide natural light and a view inside for security checks. They also give the building a residential character. The electrical wiring for the lighting and heat pump operation is a separate system from the photovoltaic system. The wiring layout is shown in Figure 2-36 terminating at a separate house panel.

\subsection{MECHANICAL DESIGN}

The photovoltaic system has two primary subsystems: the array subsystem and the power conversion subsystem. The array subsystem consists of $375 \mathrm{PV}$ modules wired in a 25-series $x$ 15-parallel network. The power conversion subsystem consists of a single unit manufactured by Abacus Controls, Inc., of Sommerville, N.J.

\subsubsection{MODULE PHYSICAL DETAILS}

The module used in the array is the Block IVA shingle module, Figure 2-8, which has been designed, fabricated and qualification tested by GE under JPL contract 955401. Representative modules have satisfactorily passed the JPL qualification 
testing program consisting of a thermal cycling exposure of 50 cycles between the extremes of -40 and $90^{\circ} \mathrm{C}$, a seven-day humidity-temperature exposure, a wind resistance test per the requirements of UL997, a twisted mounting surface test, and a hail-impact test using 1.0-inch-diameter ice balls.

The module has a series string of 19 100-mm solar cells fabricated by SOLEC, International, Inc., of Hawthorne, California, for a total cell area of 0.1480 $\mathrm{m}^{2}$. The module glazing is SUNADEX tempered glass, 4.8-mm thick. The exposed module area is $0.1955 \mathrm{~m}^{2}$ resulting in a module packing factor of 0.757 . The weight of each module is $3.9 \mathrm{~kg}$. The positive and negative leads from each module are UL-approved flat conductor cables (FCC) developed by AMP, Inc. These FCC leads consist of polyester insulated copper foil strips (equivalent to AWG 12) which have varying lengths depending on whether the assembly is to be used as the positive or negative lead. The outer end of each FCC is terminated with a AMP. patented, crimp-type connector which was developed, and has been UL-approved, for under-carpet AC-power distribution systems. The stripped end of each FCC is soldered to the appropriate cell interconnectors to form the terminations for the module.

The details of the module construction can be explained with the aid of Figure 2-9, which shows a sectional view of the laminated assembly at the transition between the exposed glass-covered portion and the overlapped flexible substrate position. The modules are the same as used in the Northeast RES, Reference 4 .

\subsubsection{Coverplate}

The glass coverplate, which is the rigid exposed portion of the shingle module, is 4.8-mm-thick ASG SUNADEX glass. This embossed low-iron soda lime glass is cut to the required hexagon shape and thermally tempered to achieve a mean modulus of rupture in bending of $138 \mathrm{MPa}(20,000 \mathrm{psi})$. The solar cells are bonded to the embossed surface of the glass.

\subsubsection{Cell Bonding Adhesive}

A transparent bond between the cells and the glass coverplate is achieved by the use of an experimental silicone pottant developed by GE Silicone Products Depart- 


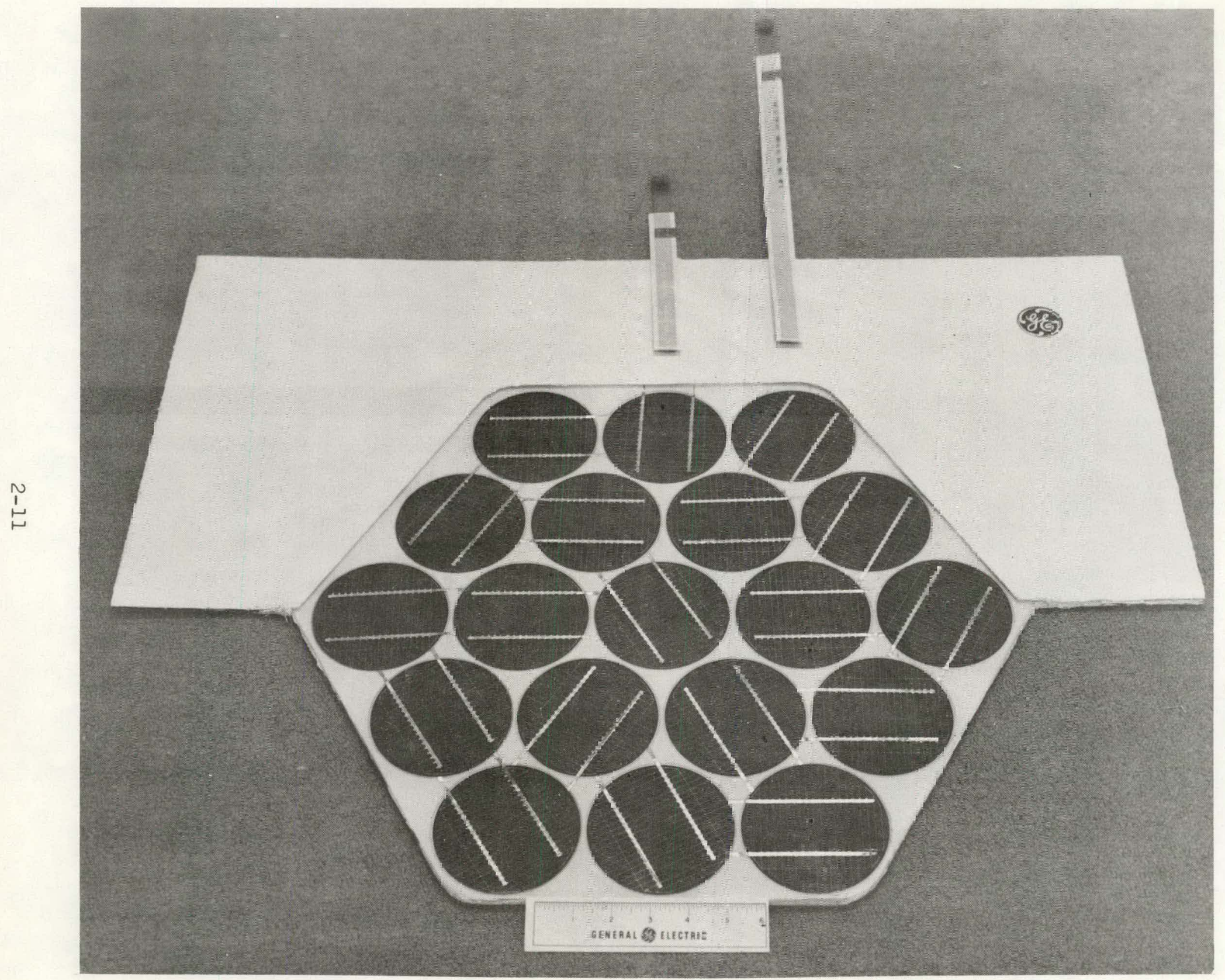

Figure 2-8. GE 3lock IVA Py Shingle Module 


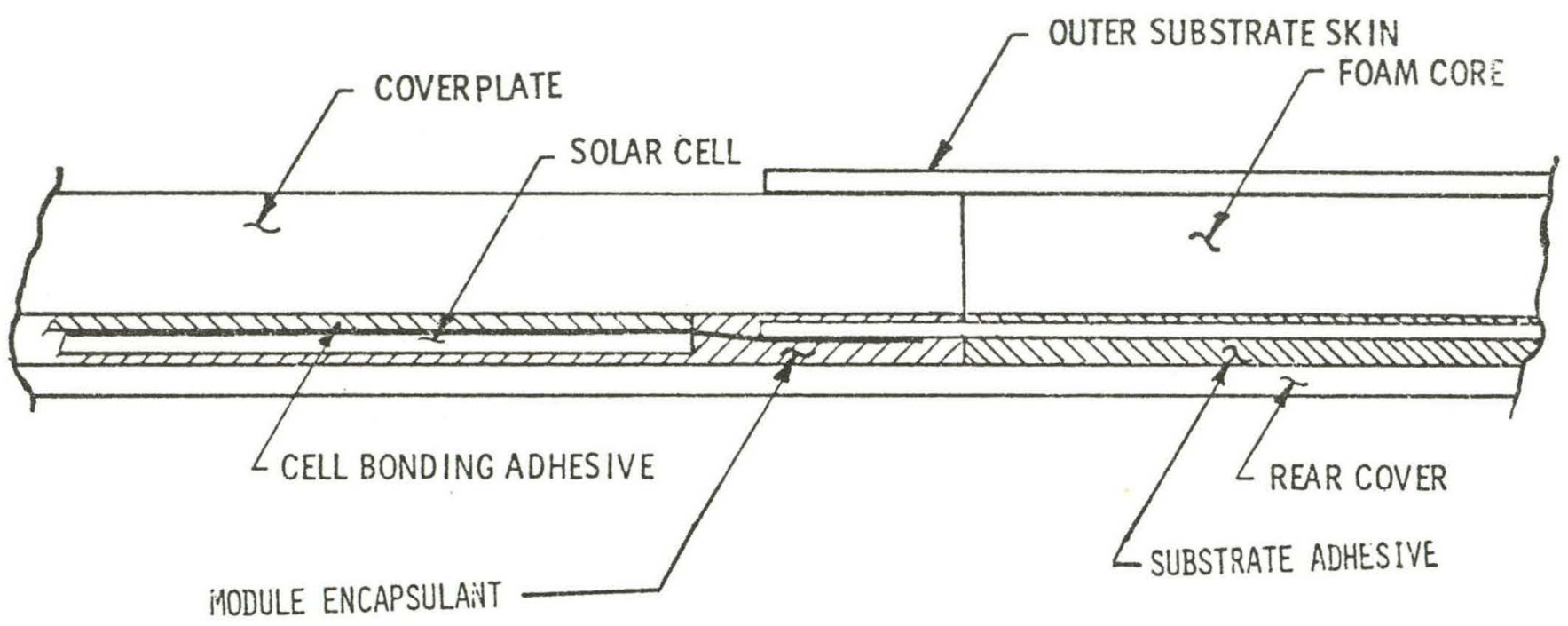

Figure 2-9. Shingle Module Construction Details

ment specifically for photovoltaic applications of this type. Designated by the number 534-044, this pottant requires no primers to achieve adequate adhesion to the glass and to the solar cell and can be cured at room temperature.

\subsubsection{Outer Substrate Skin}

The outer substrate skin is BF Goodrich FLEXSEAL which is a $6 \times$ polyester scrin reinforced white HYPALON roofing membrane. HYPALON is a synthetic muber with excellent weathering characteristics, low moisture vapor transmission rate, good oil and chemical resistance, and good abrasion and puncture resistance. The scrim reinforcement provides excellent tear resistance to prevent roofing nail tearout under wind loading conditions.

\subsubsection{Foam Core}

The foam core of the shingle substrate is 4.8-mm ( 0.188 -inch)-thick L-200 closedcell polyethylene foam manufactured by Rodgers Foam Corporation. This foam provides a low-cost, low-density filler material to maintain a nearly uniform 
shingle thickness. Material screening tests have indicated that this foam is the lowest cost material available with the required high temperature $\left(95^{\circ} \mathrm{C}\right)$ survivability.

\subsubsection{Rear Cover}

The rear cover, which covers the entire rear surface of the shingle module, is cut from 1.5-mm-thick "Pan-L-Board" manufactured by Mead Paperboard Products.

Pan-I-Board is a weather-proofed, fire-resistant, pressed paperboard panel which Mead claims has endured 17 years of outdoor weathering in Wisconsin. This rear cover provides a low-cost barrier against the entry of water and moisture from the underside and also provides some degree of protection against penetration by sharp objects during handling.

\subsubsection{Substrate Adhesive}

The adhesive used to laminate the various layers of the substrate is M6338 Super White Silaprene manufactured by Uniroyal. This material is a blend of high solid elastomeric compounds which provides excellent bond strength to most surfaces without priming, heating or mixing.

\subsubsection{Module Encapsulant}

The space between the solar cells and the module rear cover is occupied by an encapsulant whose primary function is to prevent moisture from reaching the solar cells. A GE Silicone Construction Sealant, which is identified as Siliglaze SCS2402, has been selected for this application. Thio material, which is a onecomponent construction sealant, has excellent adhesion to glass and provides the white diffusely reflective medium in the interstitial spaces.

\subsubsection{Flat Conductur Cable Assemblies}

Two flat conductor cable (FCC) assemblies, which are manufactured by AMP, Inc., are provided in each module. Figure 2-10 shows the dimension characteristics of the FCC. The stripped end of each FCC is soldered to the appropriate cell interconnectors to form the terminations for the module. Strain relief of these solder joints is provided by bonding to FCC within the substrate lamination between the rear core and the foam core. 


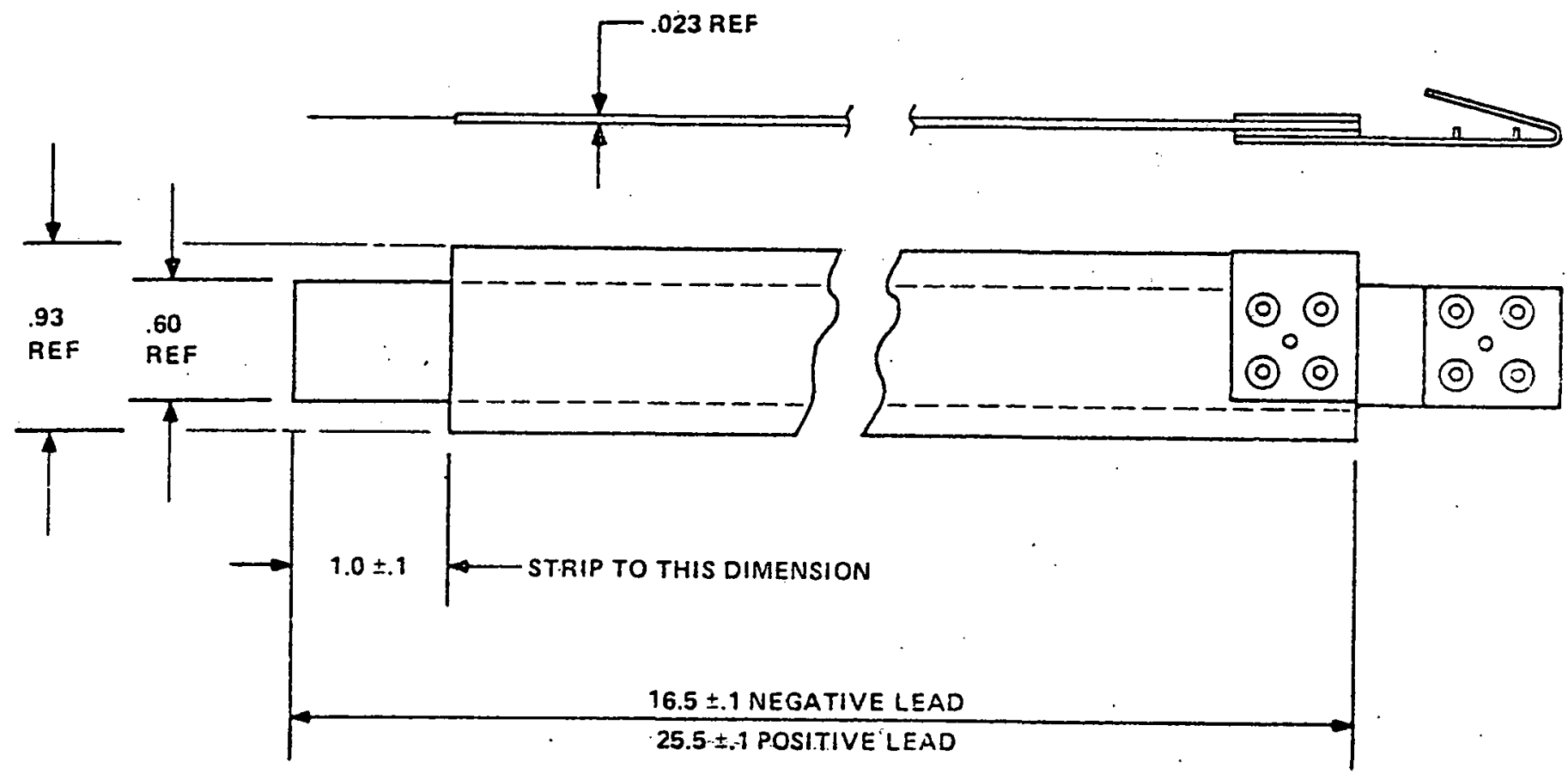

Figure 2-10. AMP, Inc., Flat Conductor Cable Assembly

Figure 2-11 shows a plan view of the module. To complete the array installation, different types of "dummy" shingles are also used. The dummy shingles are constructed of rolled asphalt roofing material, cut to the shape of the active PV module, and laminated to a back roofing material by heat. This provides a dummy shingle with the same thickness as the "active" modules for smooth transitions of the rakes and ridge of the roof.

\subsubsection{MODULE MOUNTING DETAILS}

The shingle module can be classified as a direct-mount system installation. It provides a weather-tight roof surface by virtue of its overlapping installation which is similar to a conventional asphalt shingle roof. Figure 2-12 shows a schematic of the overlapping technique on top of the roofing felt.

The mechanical attachment of the module to the roof sheathing uses a special split washer under the roofing nailhead as shown in Figure 2-13. Two through holes, which are larger than the nailhead but smaller than the washer diameter, 


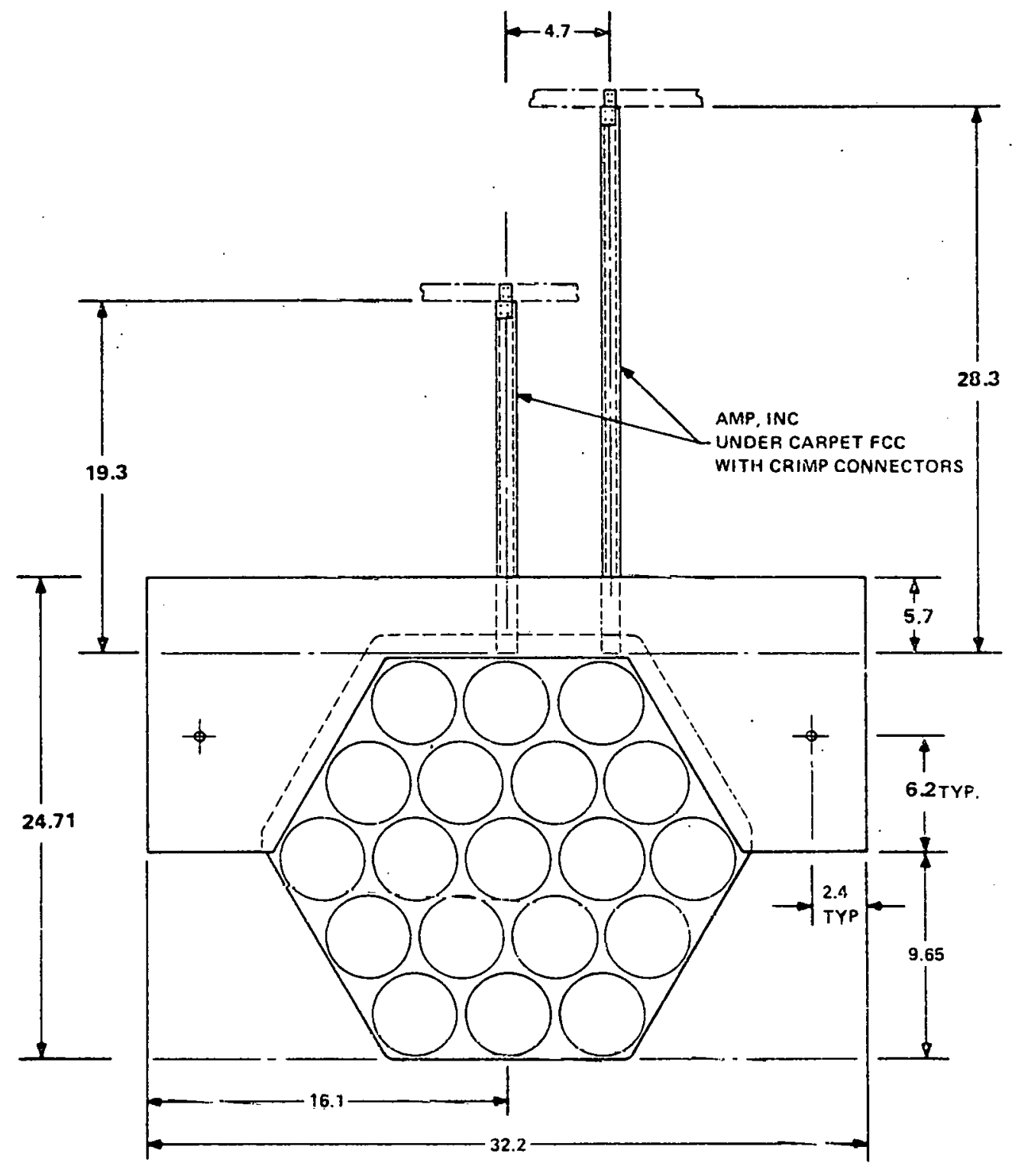

Figure 2-11. Dimensions of the Block IVA Shingle Module 


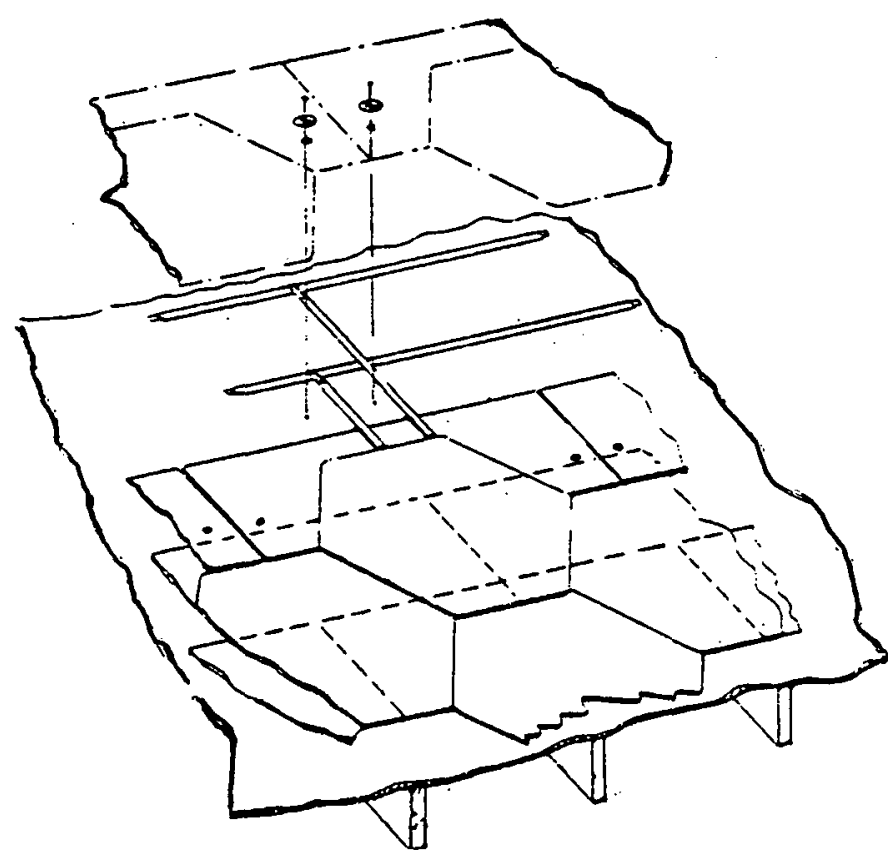

Figure 2-12. Typical Overlapping Module Installation Technique

are provided in the module substrate at the locations indicated in Figure 2-11. The use of the large split washer under each nailhead permits the release of these attachments to the roof sheathing after the roof has been completely installed. A slender tool, which can be easily inserted between the shingle layers, can be engaged with the slot in the split washer and used to extract the washer, thereby releasing the tension load at the attachment point and permitting the shingle to be removed. Figure 2-14 shows the nail and washer mounting of two adjacent modules.

The weight of the installed photovoltaic roof array is approximately $20 \mathrm{~kg} / \mathrm{m}^{2}$ ( $\left.4.1 \mathrm{lb} / \mathrm{ft}^{2}\right)$, which permits installation on conventional roofs without structural modifications.

\subsubsection{MODULE MOUNTING PROCEDURE}

The installation starts with standard black roofing felt paper covering the plywood sheathing. Dimensional lines are marked on the felt to position horizontal 


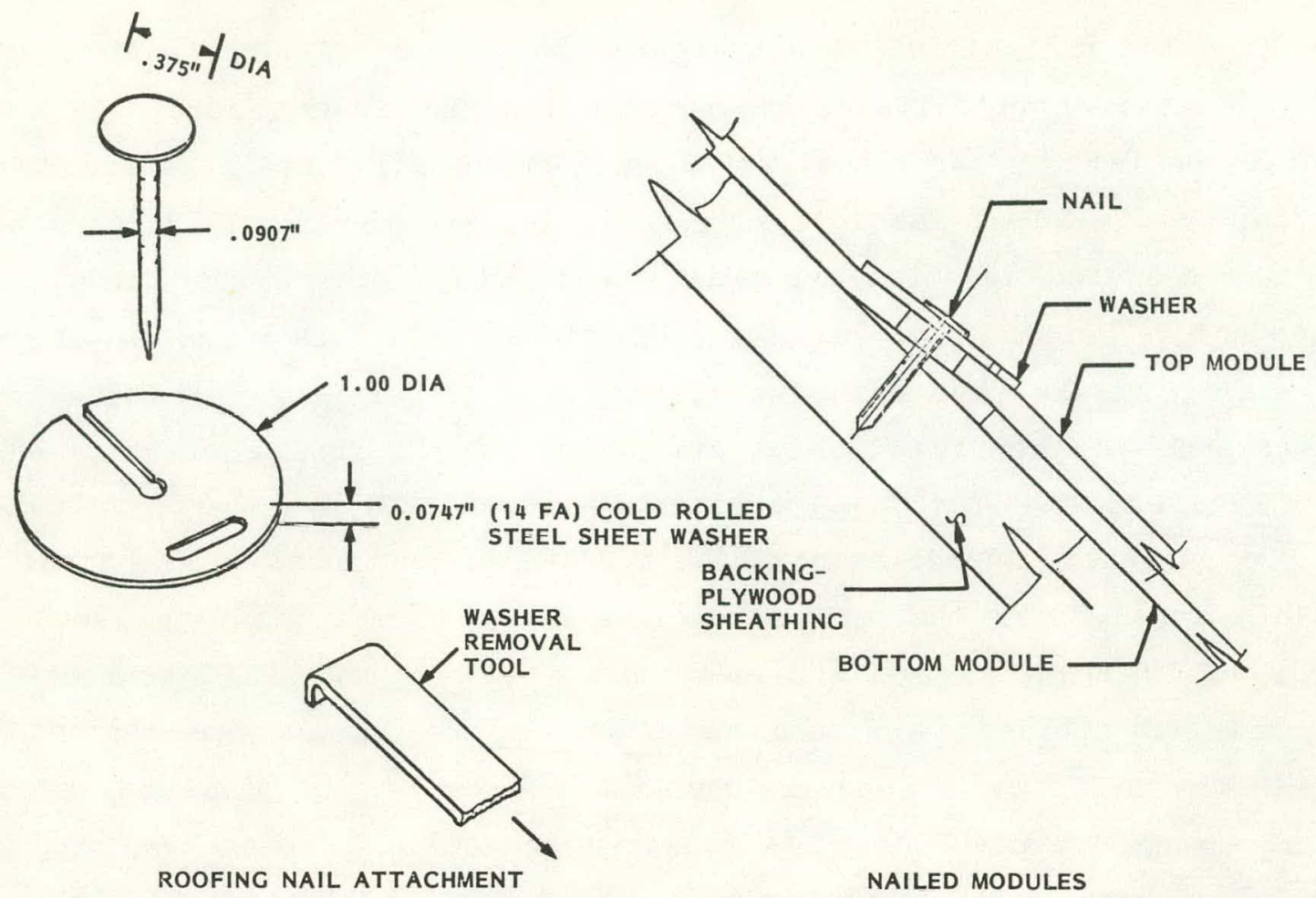

Figure 2-13. Roofing Nail Attachment of the Blnck IVA Shingle Module

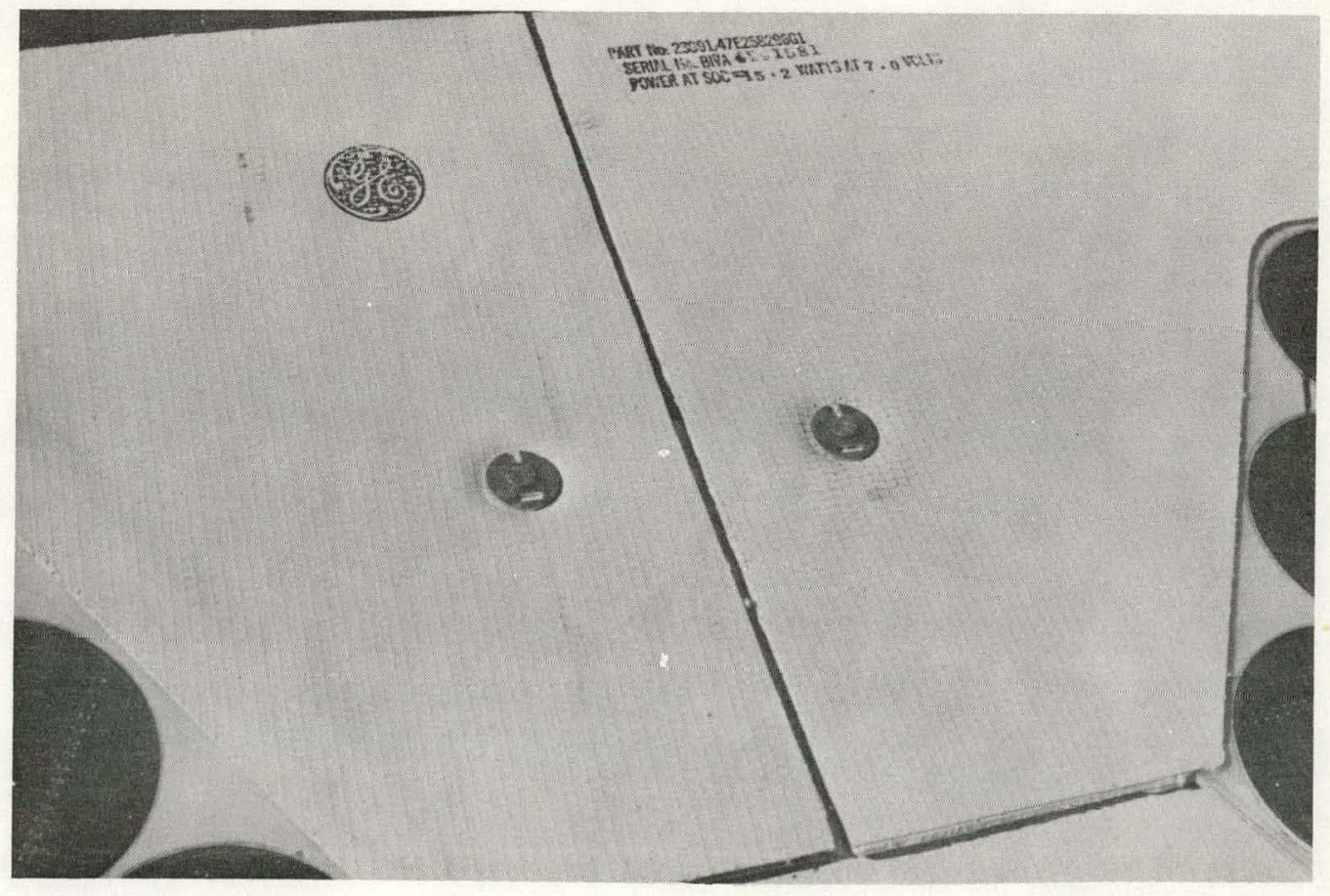

Figure 2-14. Mechanical Module Mounting 
FCC wire runs and the initial shingle course positions. The horizontal FCC runs are located based on established dimensions from the eave, Figure 2-15, and are attached to the felt by periodically taping. The positive and negative FCC runs, at the ridge and eave of the roof, respectively, are the system busbars and are routed to a selected location near the ridge. Ultimately, they transition to round conductors in an enclosed terminal block. The installation of shingle modules starts at the eave with the placement of two courses of rolled roofing which functions to preserve the watertightness of the roof along this edge, as shown in Figure 2-16. The first course of active shingle modules is nailed in place. The negative FCC cables of these modules are attached to the first row of FCC cable which becomes the system negative busbar. The positive leads of the first row of PV shingles are attached to the second row of FCC cables (Figure 2-17). The FCC cables are folded as shown in the figure for replacement if required. The next row of modules can then be nailed in place and electrical connections made, Figure 2-18. The negative bus running along the rake to the ridge is also shown in Figure 2-18 and the installation of a dummy shingle in the second row is noted.

To proceed up the roof, ladders with horizontal planks provide a convenient work platform (Figure 2-19). The ladders are shown mounted from the ground; however, on an actual house installation they could be hooked and secured over the ridge. The platform is easily moved to adjust the working level up the roof. Modules are installed to within a few feet of the roof peak (Figure 2-20). Dummy shingles are used to complete the weather seal at the ridge of the roof and also along the two edges. Note that moderate pressure from leaning against the modules is allowed. The modules can be walked on if the weight is equally distributed over the glass surfaces by using hexagonal wooden covers with neoprene pads. This procedure is not highly recommended and it was not tried during the installation.

The complete array installation procedure is summarized in Figure 2-21. A set of installation safety notes is included in Appendix A.

\subsubsection{INVERTER PHYSICAL DETAILS}

The power conversion subsystem consists of the basic inverter, a DC input filter, a transformer, array voltage control circuitry, and amplitude control and sensing circuits. The complete subsystem is packaged into a single 


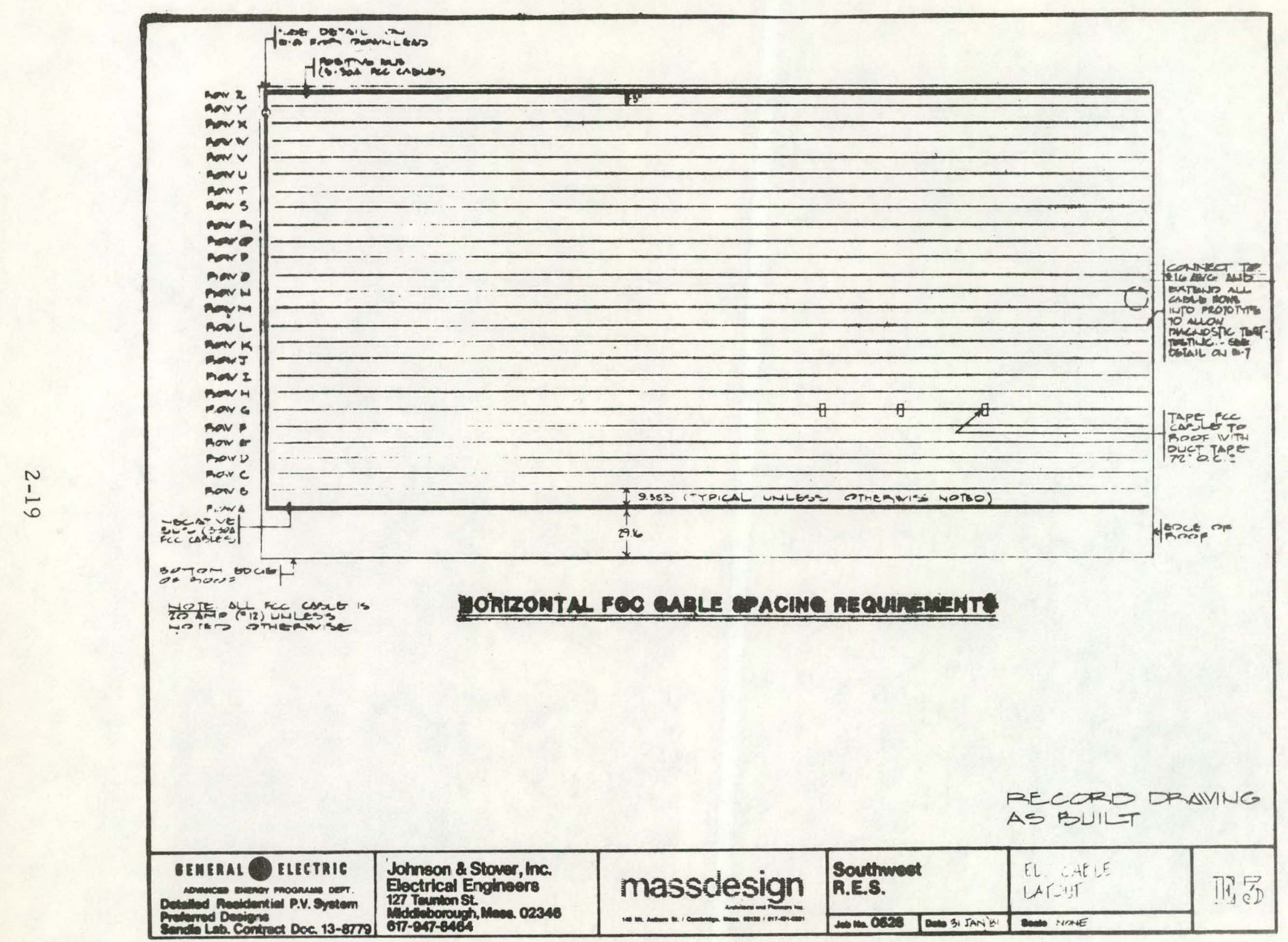




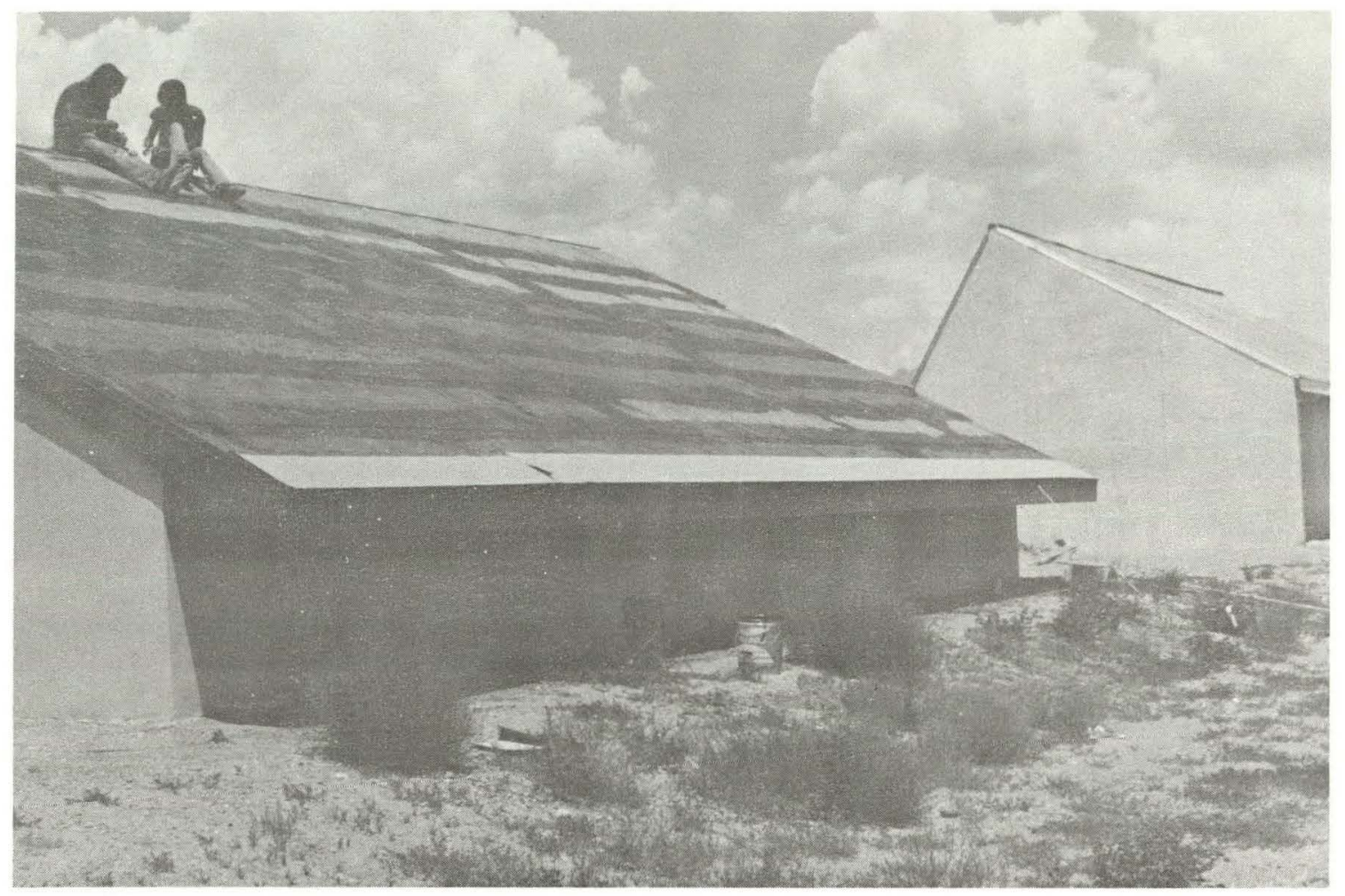

Figure 2-16. Two Rows of Rolled Roofing Dummy Shingles

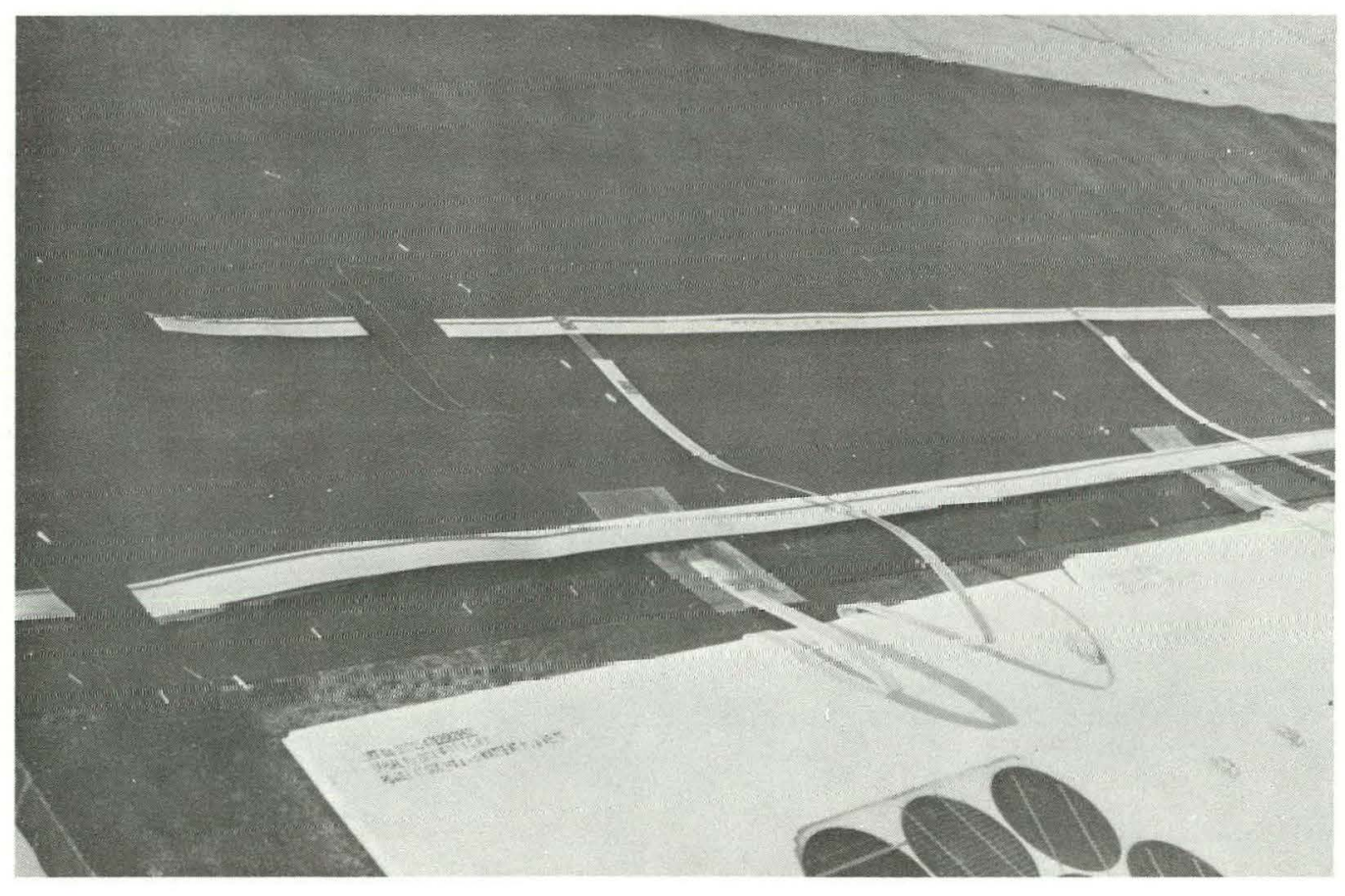

Figure 2-17. Electrical Connection of the Modules 


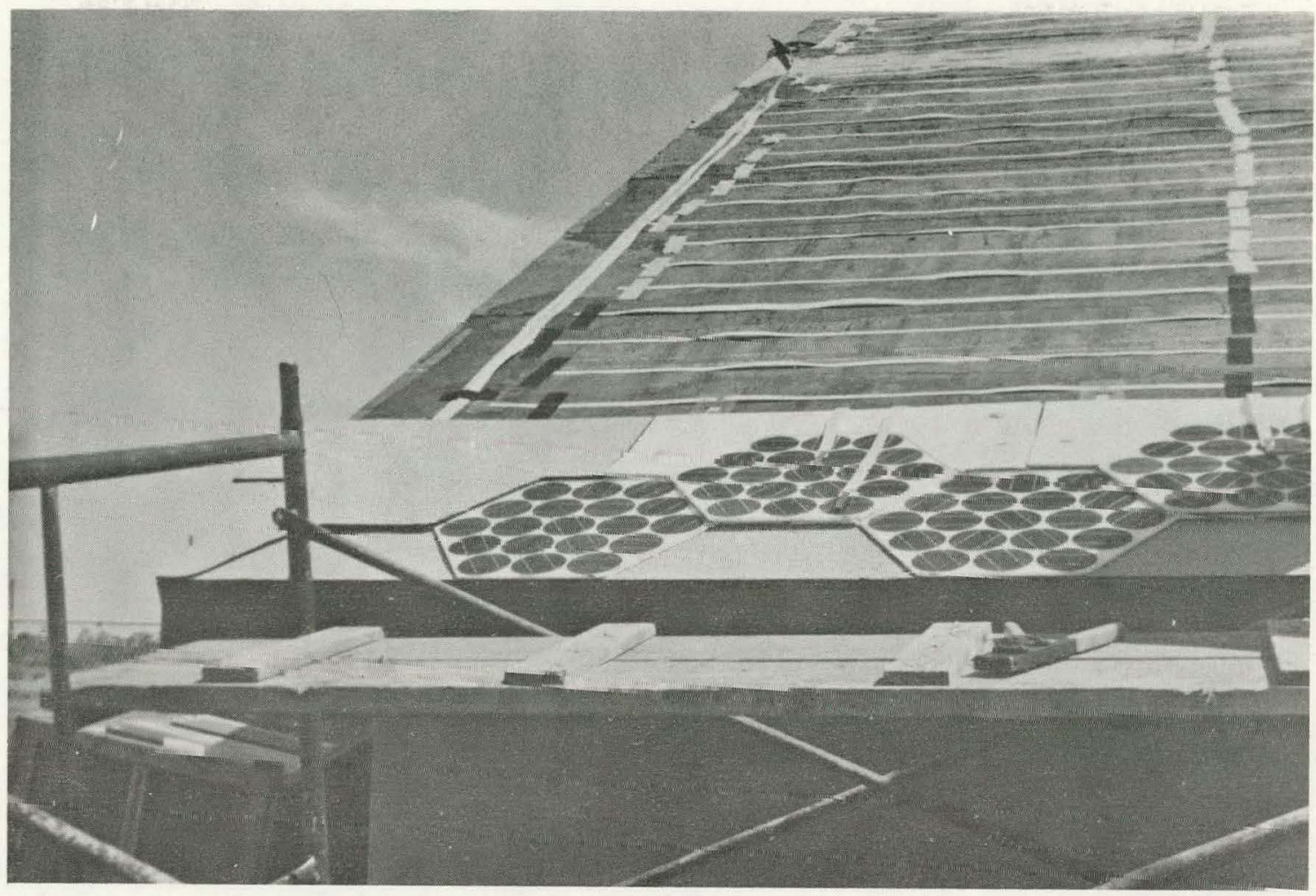

Figure 2-18. Two Rows of Installed Modules

unit. The unit is floor mounted as shown in Figure 2-22. The unit dimensions are $1.6 \mathrm{~m}$ high by $0.6 \mathrm{~m}$ wide and $0.76 \mathrm{~m}$ deep. Both front and back doors are provided on the unit for access to the circuitry. A thermostatically controlled fan is included in the unit to dissipate heat.

\subsubsection{INVERTER INSTALLATION REQUIREMENTS}

The Sunverter is a four wire unit, i.e., 2-wire DC input and 2-wire 240 VAC output. The unit is floor mounted as previously stated and should be located with sufficient open area around it to permit adequate heat dissipation. No additional specific mechanical installation requirements exist for the unit. The unit is mounted on casters for easy movement.

\subsection{ELECTRICAL DESIGN}

The electrical system is connected in parallel and synchronized with the utility. The system provides energy for both space conditioning and conventional household electrical load requirements. Power generated by the array in excess 

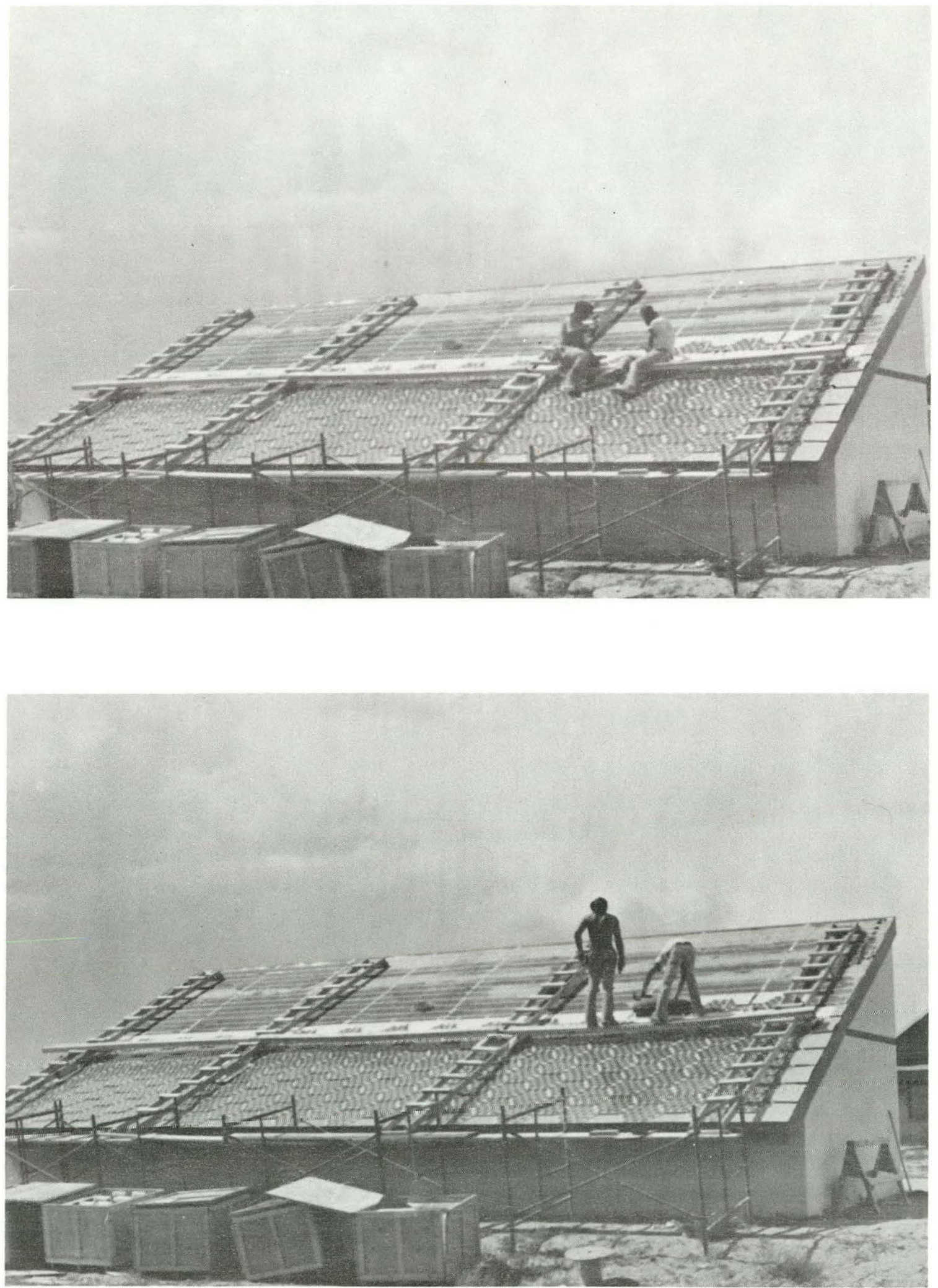

Figure 2-19. Ladder/Platform Installation Technique 

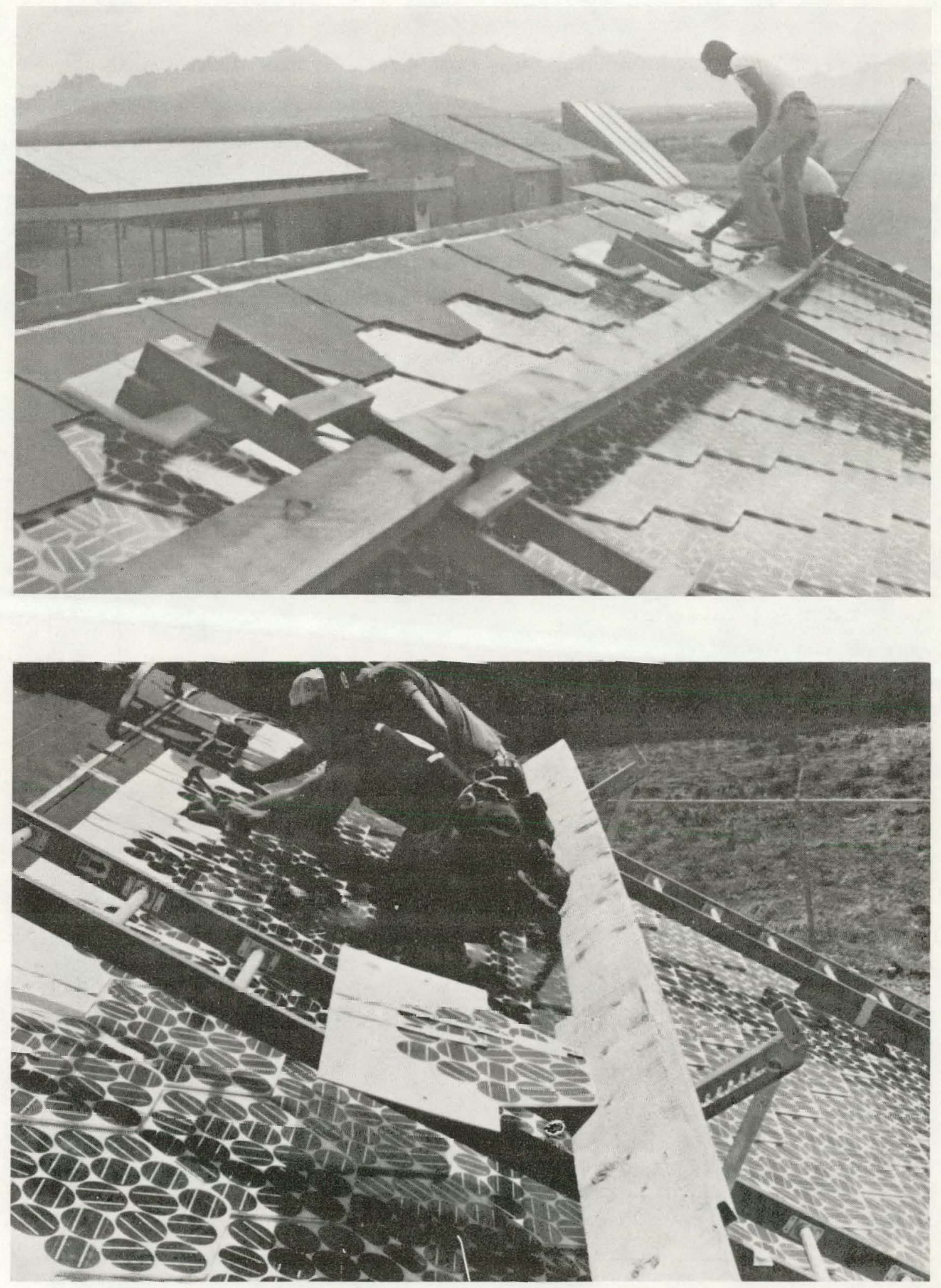

Figure 2-20. Nodule Installation Near the Roof Ridge 


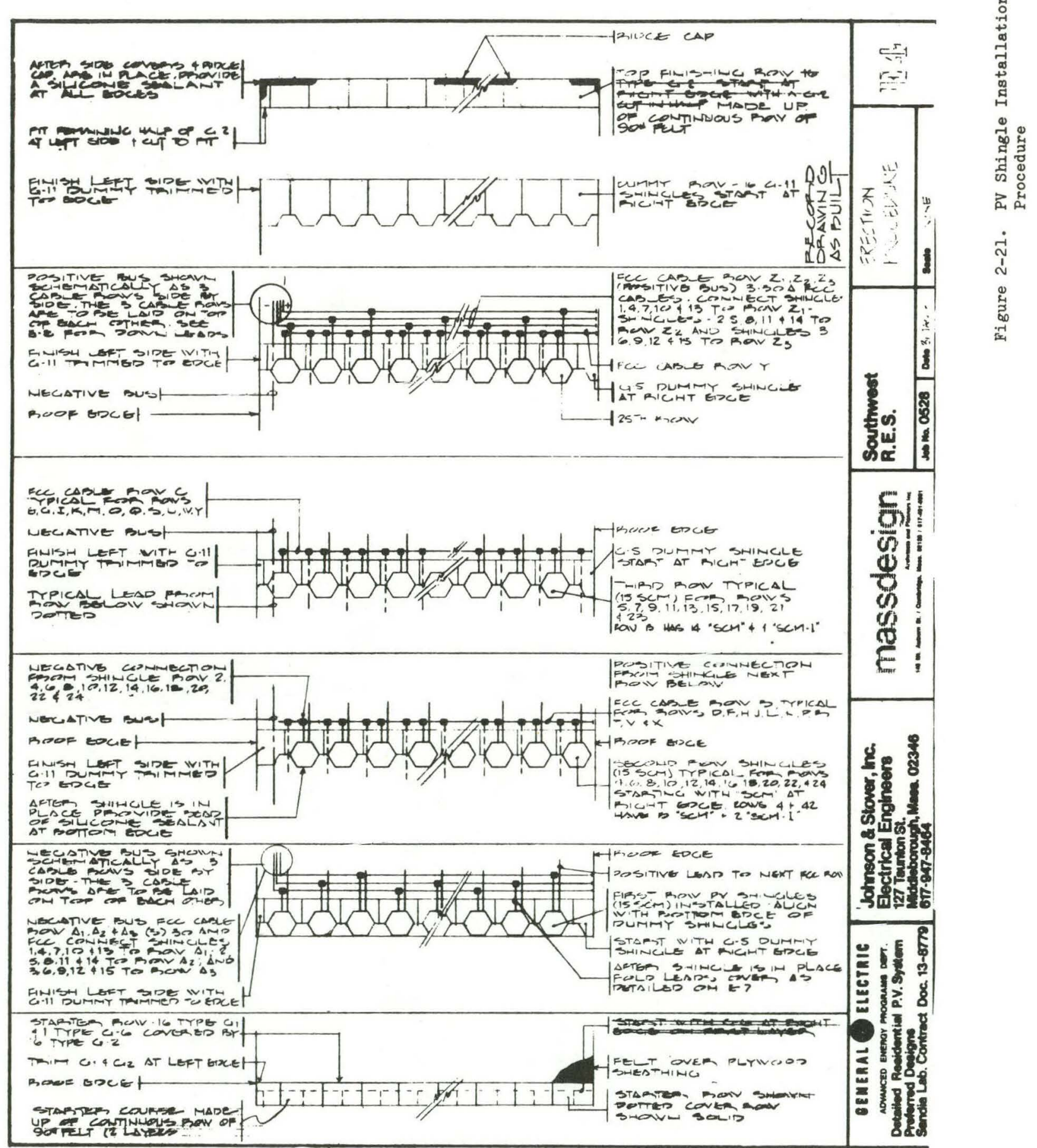




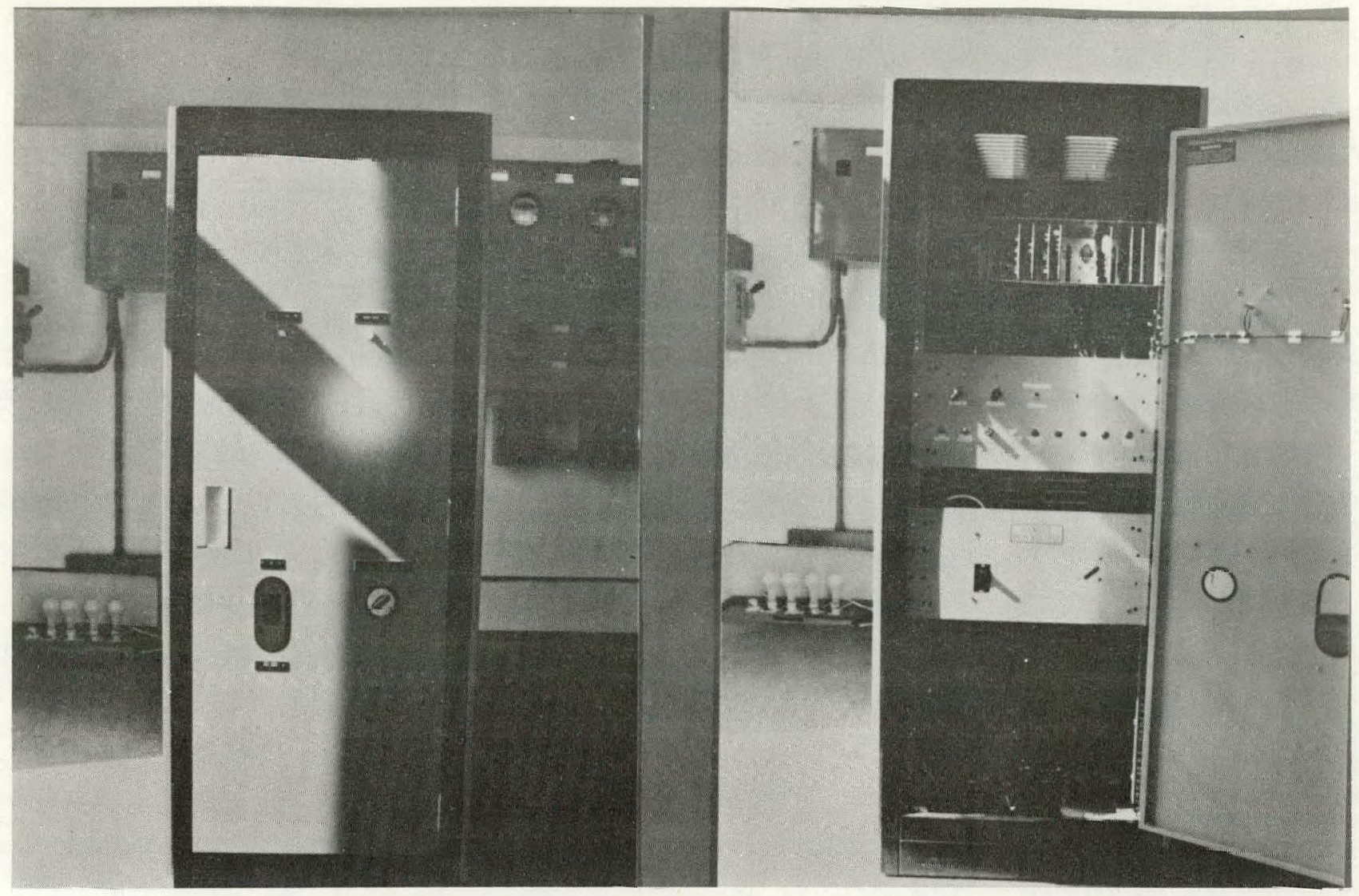

Figure 2-22. Abacus Power Conversion Unit

of residential loads is fed back into the utility grid. Residential loads in excess of the array power draw power from the utility grid. With this arrangement, all house demands are met, no electrical storage is required, and all net energy output of the photovoltaic system is used.

The system does not use blocking diodes due to the highly redundant series/ parallel module network. However, due to this arrangement, the system is not designed to be short circuited for extended periods. Short circuit conditions are not anticipated in the normal residential installation.

Complete system instullation specifications developed by Johnson \& Stover are included in Appendix B.

\subsection{MODULE ELECTRICAL CHARACTERISTICS}

The GH Block IVA shingle module shown in Figure 2-8 consists of 19 series-connected lo0mm diameter silicon solar cells. The module I-V char- 
acteristics are shown in Figure 2-23. The modules produce 15.0W under typical operating conditions $\left(100 \mathrm{~mW} / \mathrm{cm}^{2}\right.$ insolation, $\mathrm{NOCT}=68^{\circ} \mathrm{C}$, and $20^{\circ} \mathrm{C}$ ambient). The module has no internal diodes.

\subsubsection{ARRAY ELECTRICAL CONFIGURATION}

The solar array consists of 375 shingle modules connected electrically in a highly redundant series/paralled circuit arrangement with 25 modules in series and 15 parallel circuits. The module electrical circuit terminates in positive and negative busbars which are connected to cabling, run in conduit to the equipment room. The negative busbar is grounded. Figure 2-24 shows the overall array layout with each module assigned an identifying number. The electrical schematic of the series/parallel network is shown in Figure 2-25. With this highly redundant network no diodes are required in the array.

The electrical interconnection between modules is achieved with the UL-approved AMP FCC cables and crimp connectors discussed in Section 2.2.1. Connections are simply made with a crimping tool as shown in Figure 2-26. Insulating patches with adhesive are then placed over the connection to complete the installation.

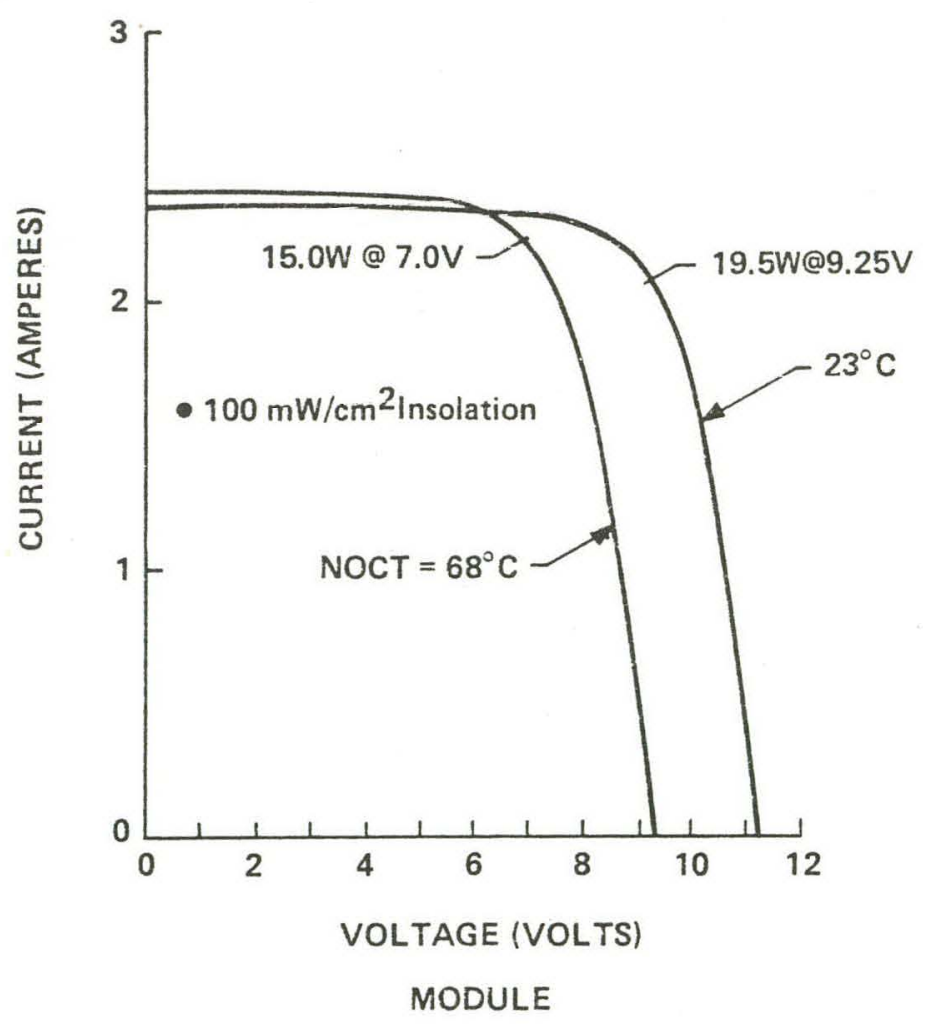

Figure 2-23. Module I-V Characteristics 


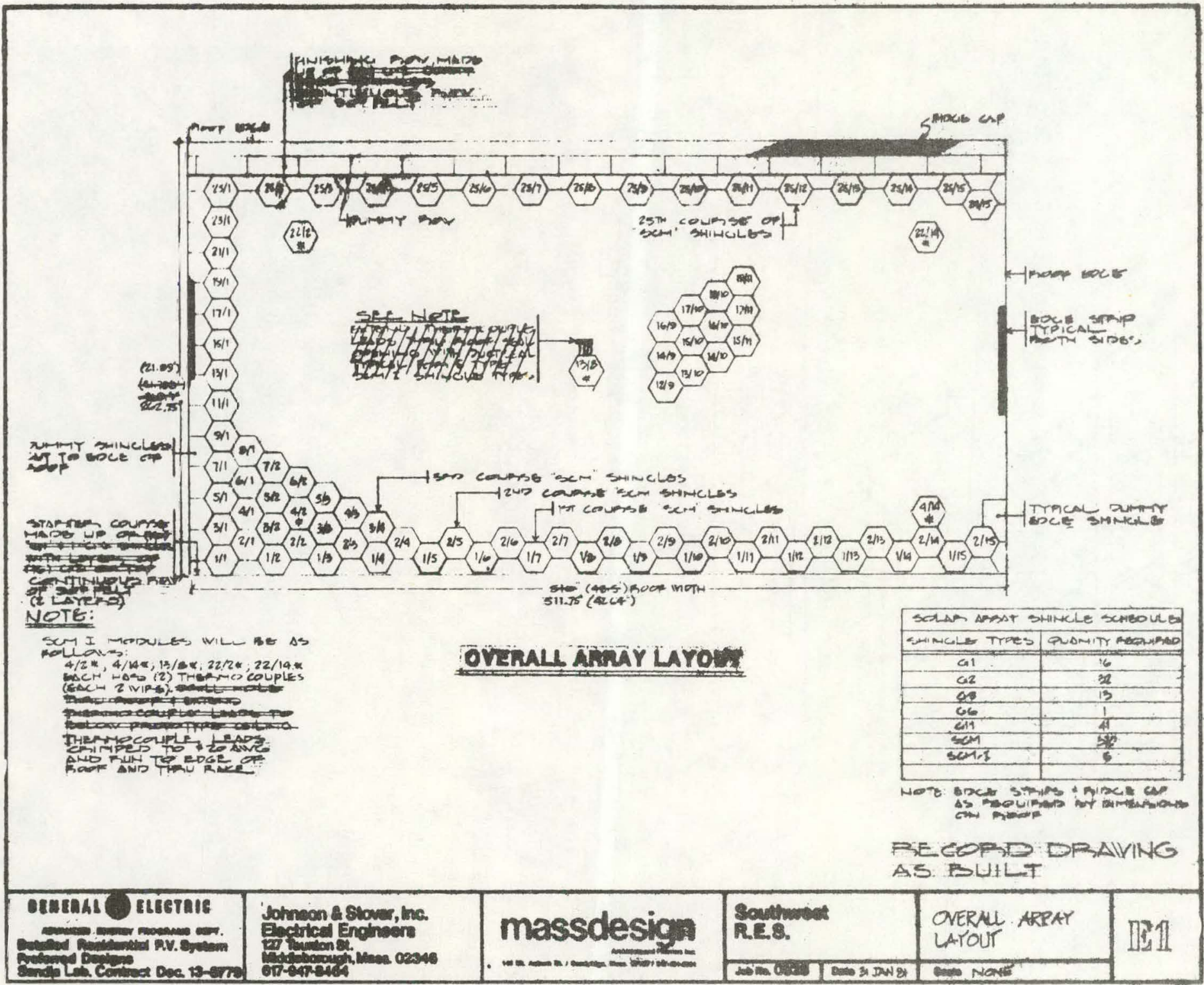

Figure 2-24. Overall Solar Array Layout 


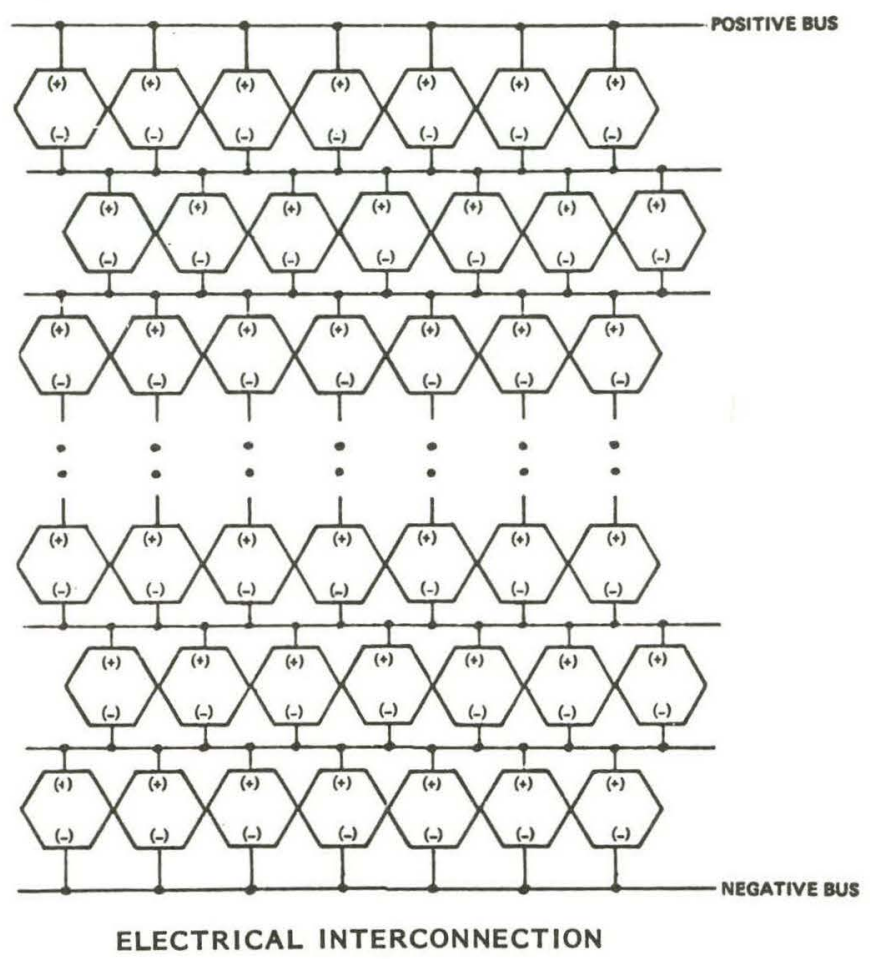

Figure 2-25. Solar Array Electrical Schematic

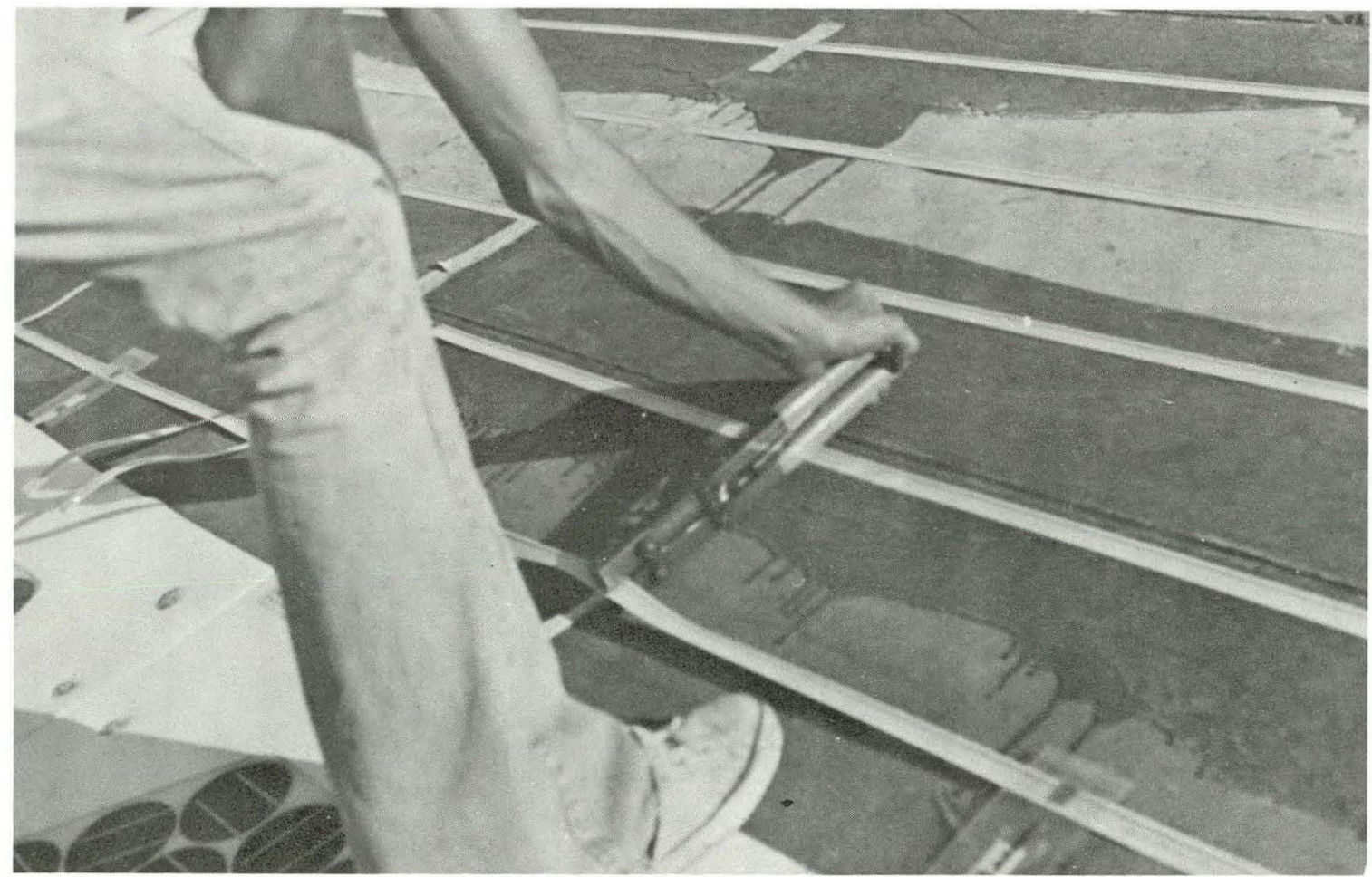

Figure 2-26. Use of the Crimp Tool for Module Interconnection 
The modules are connected in series up the roof. Figure 2-27 shows this electrical interconnection. Note that the first row of FCC cable becomes the negative bus with only negative lead connections. Similarly, the last row connections are all positive connections forming the positive bus, Figure 2-28. Since the FCC is only available in \#10 AWG or \#12 AWG equivalent cable, a triple layer of \#10 is used for both buses and $1 / 3$ of the modules in the first and last rows are connected to each layer to distribute the current in the cables.

Figure 2-29 shows typical interconnections for the whole array. The series circuits zig-zag up the roof.

The negative bus is run underneath the shingles along the rake to the ridge as shown in Figure 2-15. At the ridge, both the negative and positive FCC buses are fed through the rake (Figure 2-28) to a transition box. The transition box is supplied by AMP. The three negative and positive FCC buses are connected to a set

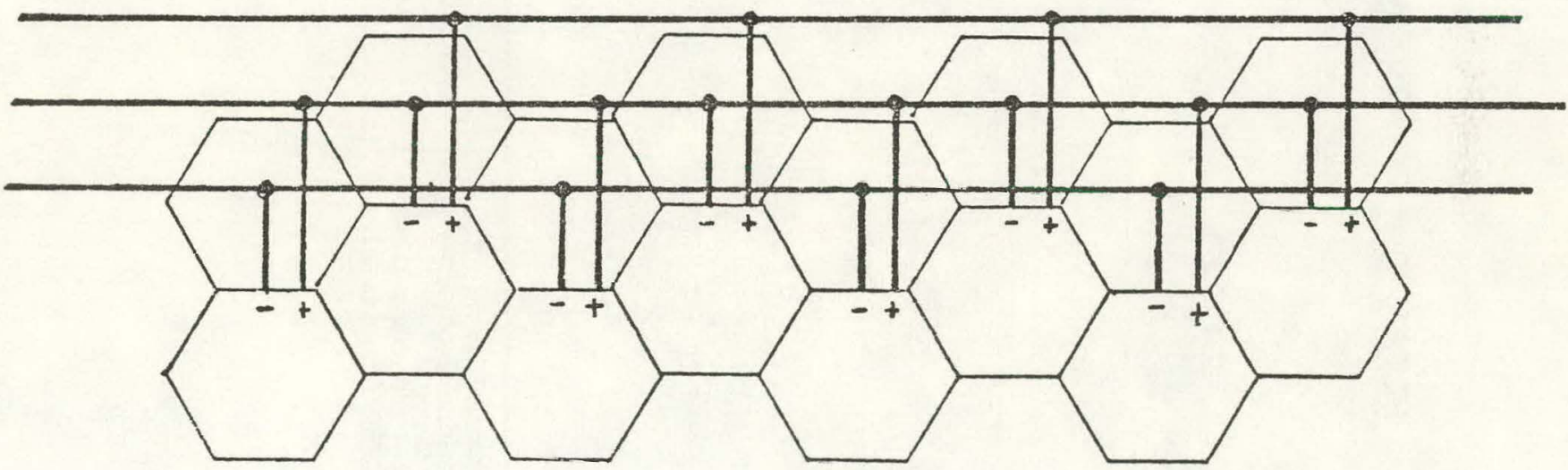

Figure 2-27. Electrical interconnection Arrangement for the Shingle Module 


\section{DETAR TOP OF ROOF AT 25TH "SCM" SHINOLE ROW}

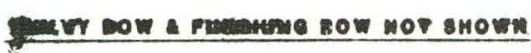

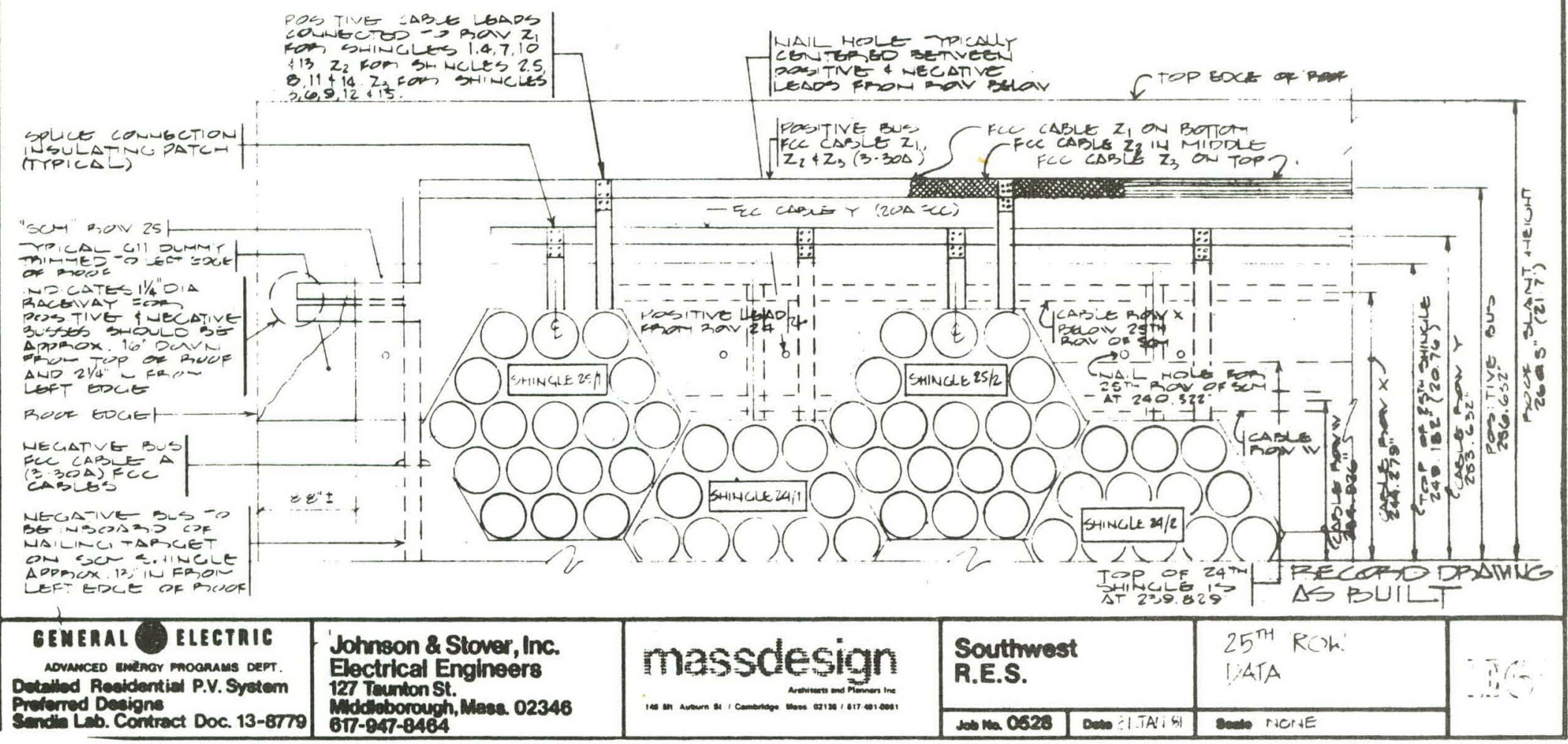

Figure 2-28. Positive Bus Connections 


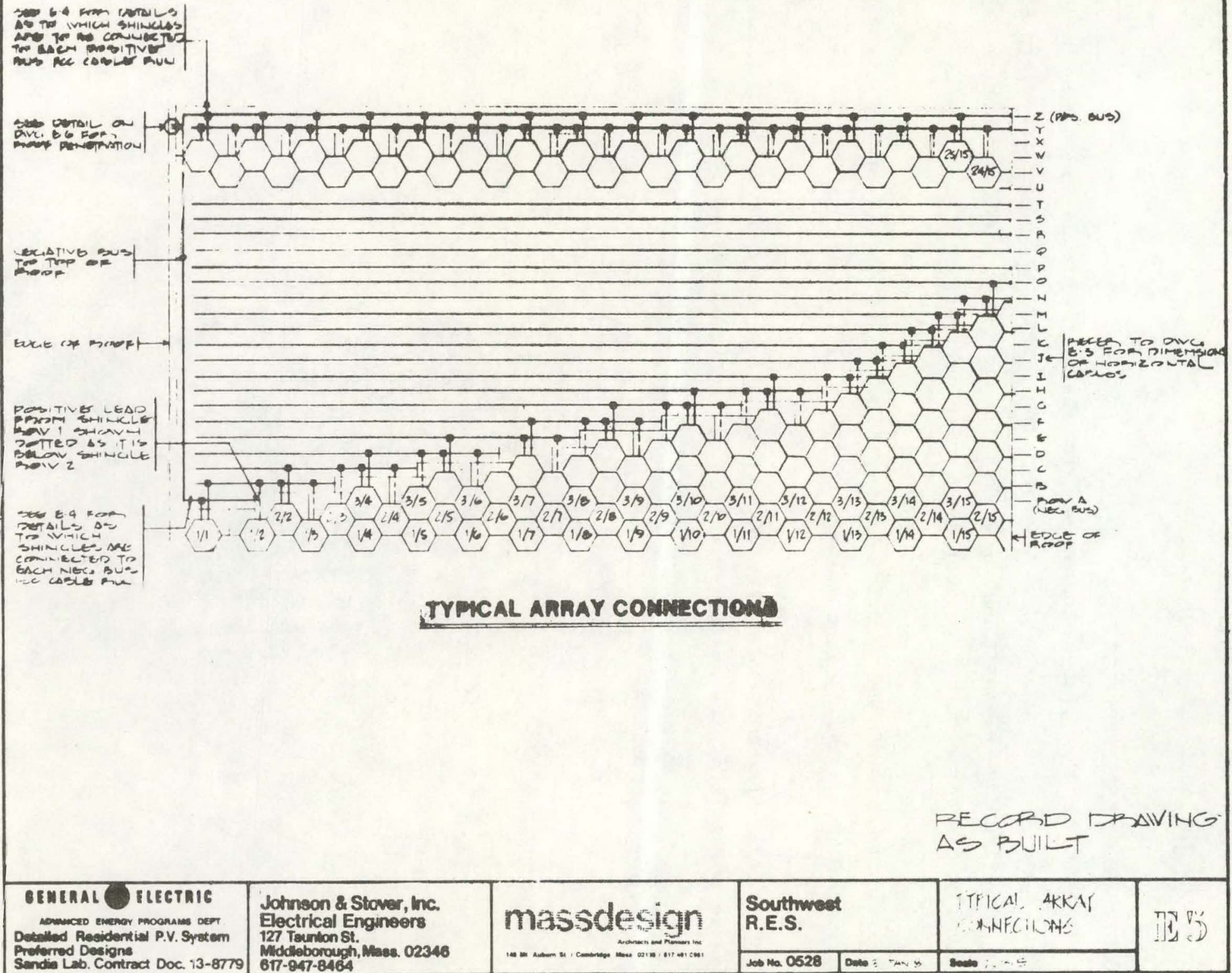


of copper plates which also have lug terminals for standard round AWG \#6 cables. Thus, the transition of the FCC buses to round cable is achieved as shown in Figure 2-30. The buses are then fed to an external disconnect as shown in Figure 2-31. This service would be installed alongside of the conventional utility service to show the dual power sources.

\subsubsection{SYSTEM ELECTRICAL DETAILS}

A block diagram of the system components is shown in Figure 2-32. The major functional elements of the system, beside the array and the inverter are described briefly. The elements shown within the inverter block in Figure 2-32 are physically located within the power conversion cabinet.

Transformer - The transformer provides both isolation of the AC and DC circuits and matching of the normal AC line voltage to the output DC voltage of the array.

DC Filter - This filter smooths the DC current flow which is subject to high harmonics as a result of the switching action of the transistors.

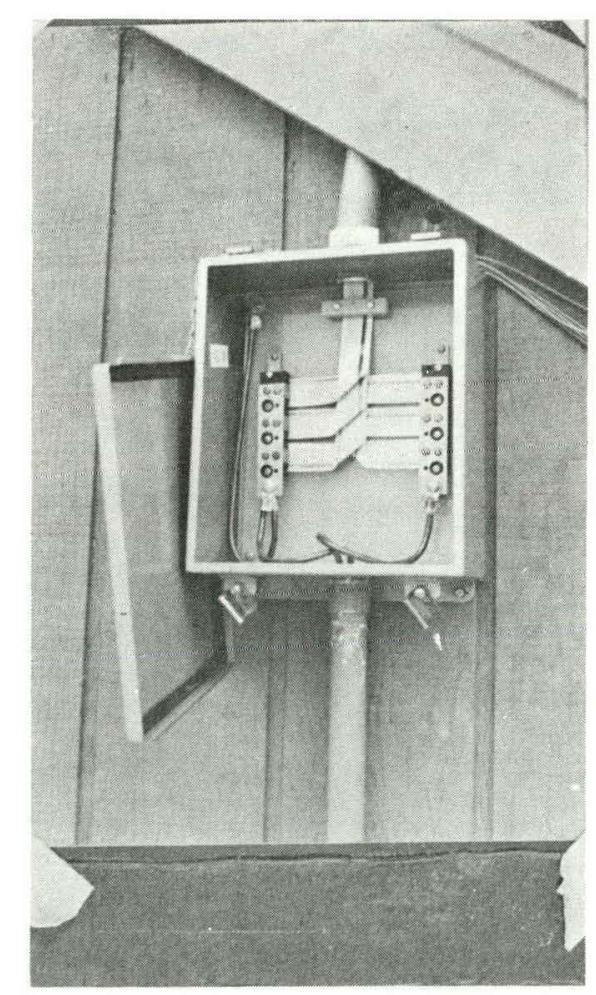

Figure 2-30. Transition Box Wiring 




Figure 2-31. DC Power Drop Line

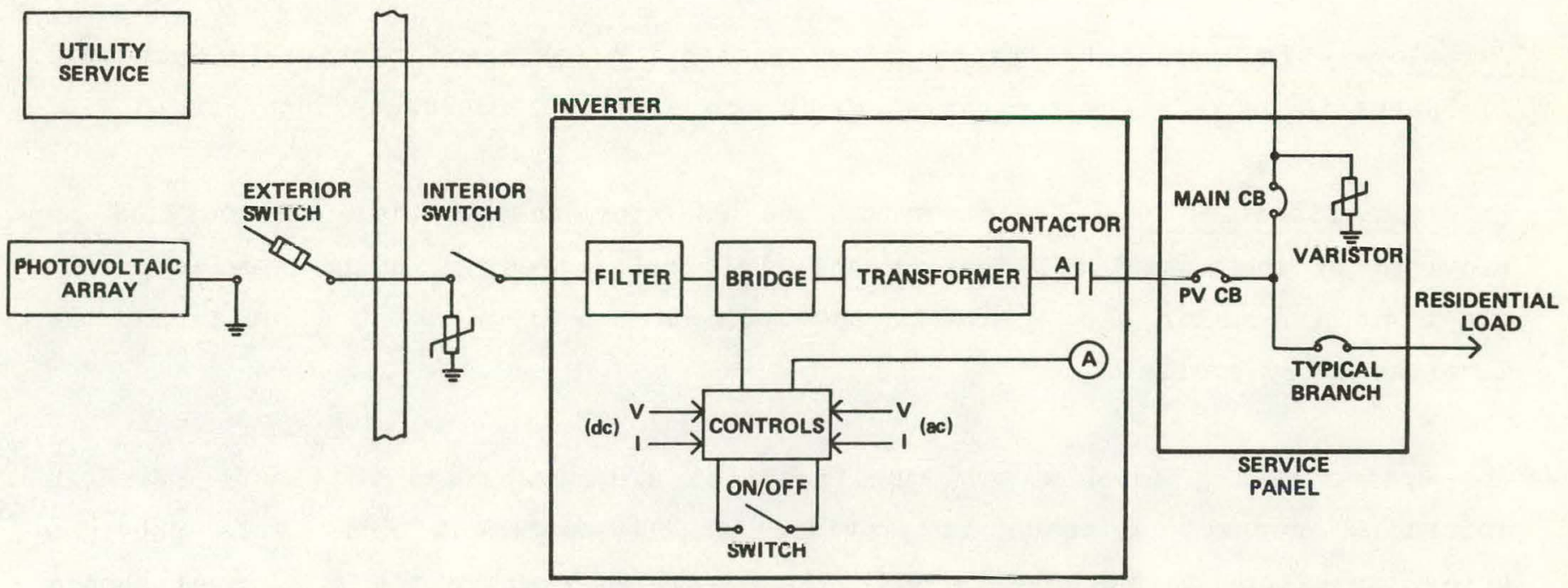

Figure 2-32. Residential Photovoltaic Block Line Diagram 
Inverter Controls - These controls provide the timing signals for firing of the transistors and, in turn, control the level and direction of power flow through the power conversion system.

Maximum Power Control - This control circuit attempts to operate the array at its dynamic maximum power point. Two algorithms exist to serve this function and they are discussed in Section 2.3.4.

RFI Filter - This filter attenuates high-frequency-output harmonics to minimize radio and $\mathrm{TV}$ interference.

Input DC Contactor - This contactor closes only when the AC Line Contactor is closed.

Output AC Contactor - This contactor closes only when the array available output power is greater than the (PCS) no-load losses.

Exterior Array Fused Switch - This switch provides a visible exterior disconnect, and is fused only if required by a strict code interpretation, since array short circuit current is only slightly over full-load current.

Varistors - Induced lightning transient protection for the inverter and household equipment is provided by the varistors on the $\mathrm{DC}$ and $\mathrm{AC}$ residence input lines.

Interior Disconnects - Isolation of the PCS for installation and service is provided by the interior DC switch and the circuit breaker in the service panel. The circuit breaker also protects the main service from short circuits in the inverter array system.

The system wiring details and specifications are summarized in Figure 2-33. An unfused disconnecting means is provided in the equipment room. This provides array isolation, in conjunction with the 60-amp breaker in the main panel should it be necessary to perform maintenance on the inverter equipment. The positive leg of the DC system is surge suppressed with a varistor on the array side of the switch. This allows surge protection of the array even if the interior disconnect switch is open. Beyond the interior disconnect switch, the DC power is carried 


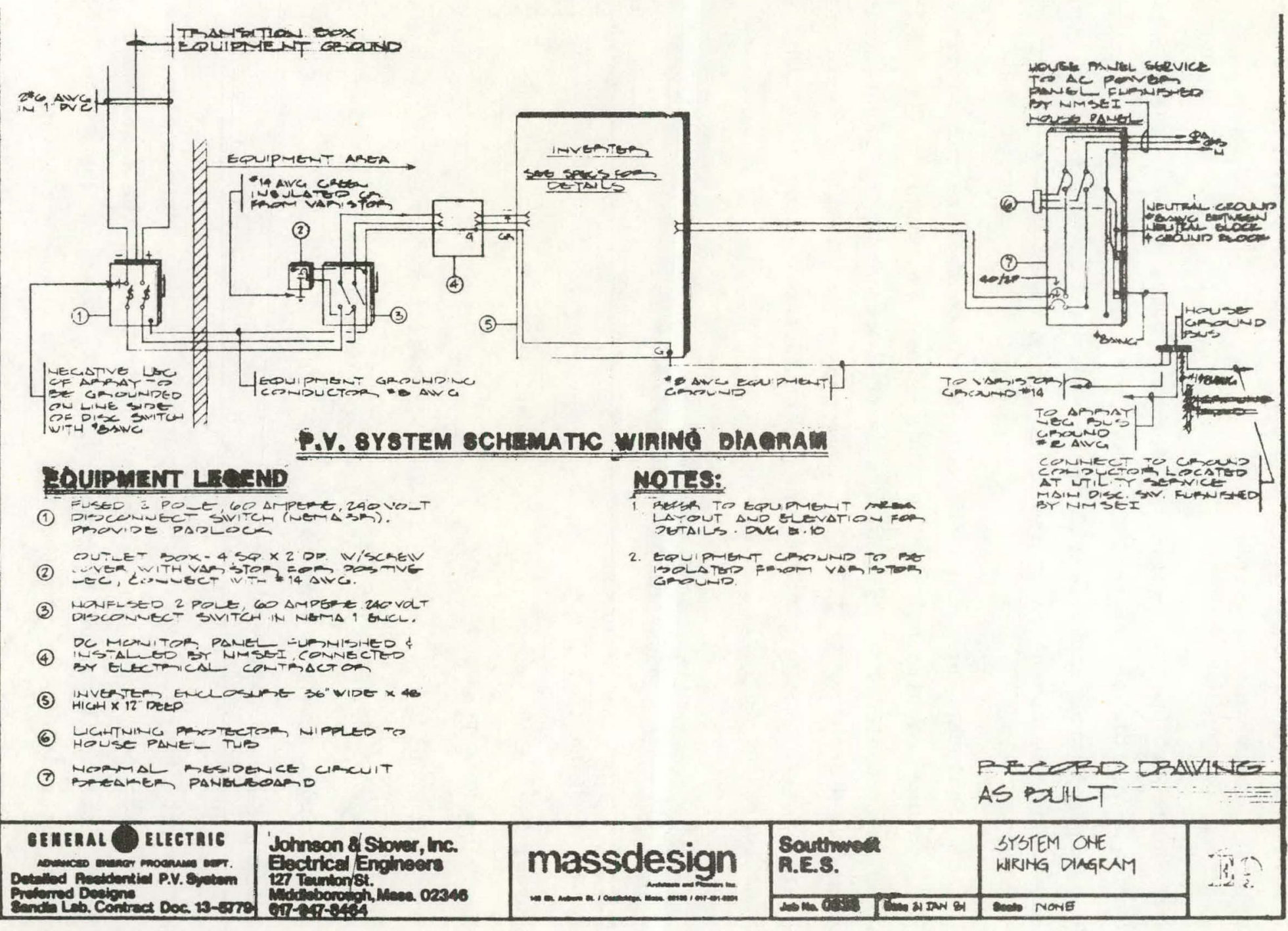

Figure 2-33. System Wiring Schematic 
through a raceway system to the inverter enclosure. The inverter's AC output connects to the service panelboard through a raceway. The service panelboard is provided with residential type lightning arrestors to provide inverter output circuit protection to induced voltage surges.

An exposed copper house ground bus is located directly below the service panelboard. This provides a visible and accessible means for terminating all grounding conductors. The equipment area contains all major equipment associated with the photovoltaic system with the exception of the solar array.

Service entry to the equipment area from the outside disconnect switch is via a thru-wall nipple. Typical equipment placement is shown in Figure 2-34. Wall installed equipment is mounted on a 3/4-inch plywood backboard. The inverter is floor mounted. Figure 2-34 also includes an equipment room elevation depicting interconnecting wiring with respect to the equipment placement plan. A tabulation of major equipment is listed in Table 2-l.

Table 2-1. Major Electrical Equipment Iist

- DC Power Transition Block

- Fused, 2-Pole 60-Ampere, 240 Volt Exterior Disconnect Switch

- Varistors, GE Type V275LA40B

- Nonfused 2-Pole, 60-Ampere, 240-Volt Interior Disconnect Switch

- Varistors, GE Type TLPI75

- House Circuit Breaker Panelboard

- Utility Service Meter Socket

Figure 2-35 shows a photograph of the inside equipment. The photograph also shows the NMSEI supplied instrumentation equipment and location. Only the floor-mounted inverter and NMSEI load-duplication equipment are not shown in the photo. The basic lighting and power layout of the prototype structure independent of the PV system is shown in Figure 2-36. 


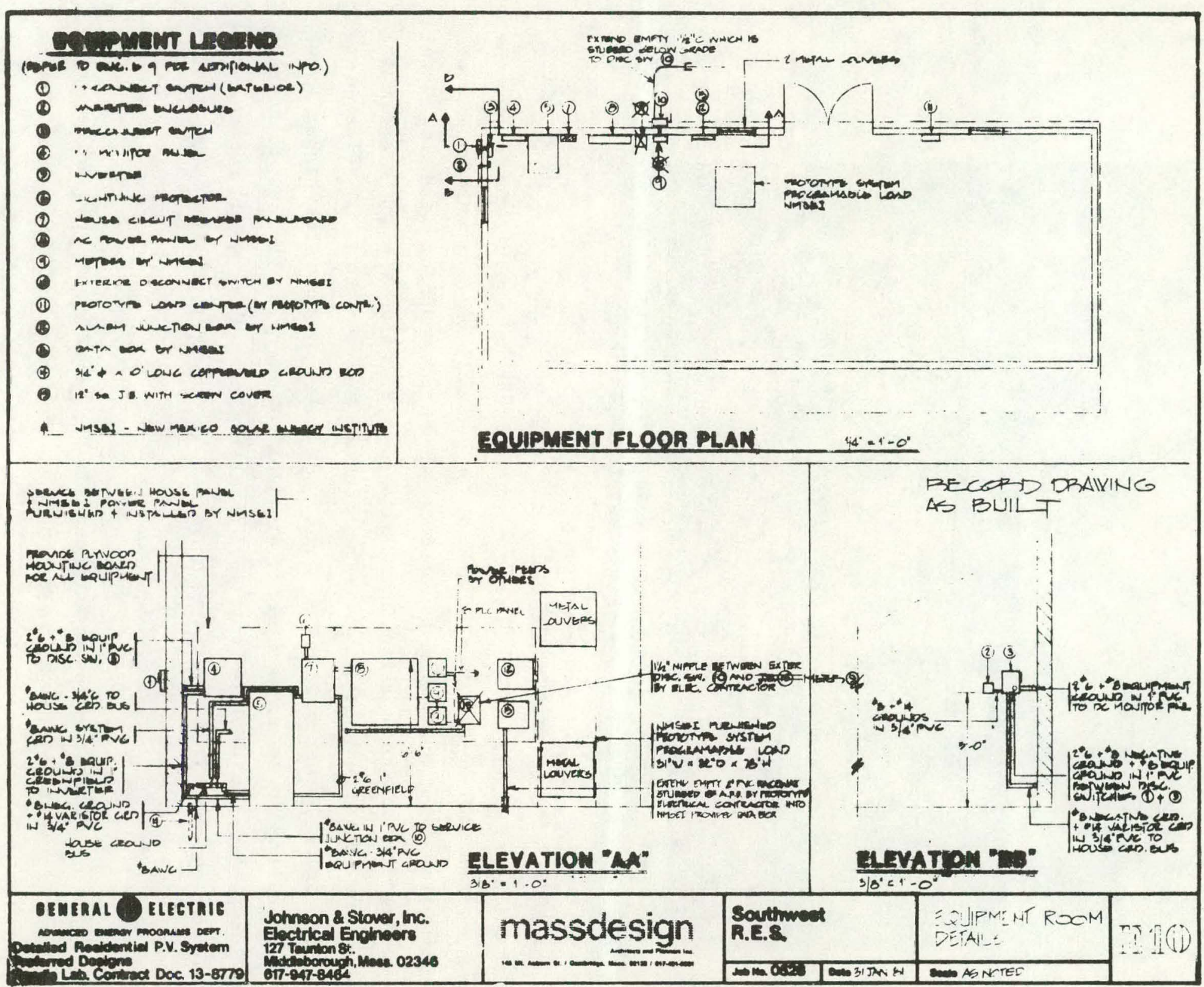

Figure 2-34. Equipment Ares Layout 


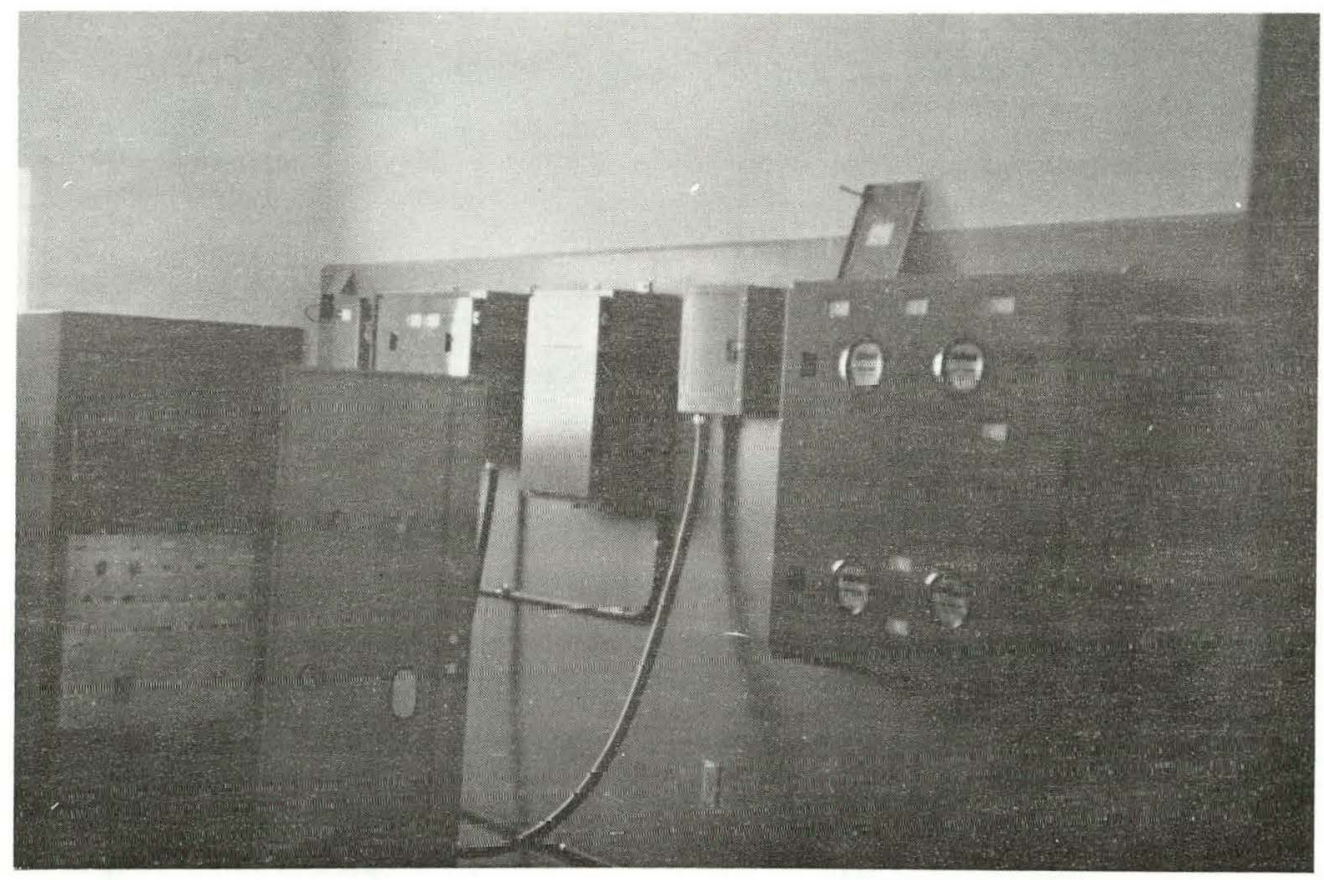

Figure 2-35. Equipment Installation

\subsubsection{POWER CONVERSION SUBSYSTEM CHARACTERISTICS}

The PCS specification (Appendix C) meets the electrical requirements of the system design. The Abacus inverter is a dual bridge unit using power transistors with digital sine wave synthesis to produce an output current with low total harmonic distortion at the utility line voltage. A functional block diagram for the inverter is shown in Figure 2-37. The digital pulse pattern is selected to eliminate low order harmonics, and a simple LC filter reduces the higher order harmonics, resulting in total harmonic distortion of only 5\%. The output current is phase locked to the utility voltage, resulting in unity power factor. The functional requirements for the Abacus inverter for this application are listed in Table 2-2.

The model 763-4-200 Sunverter accepts input of 160 to 240 VDC from an array of solar cells and converts it to 240 Volts $\mathrm{AC}$ at $60 \mathrm{~Hz}$ nominal. Output power rating is $6 \mathrm{kVA}$. 


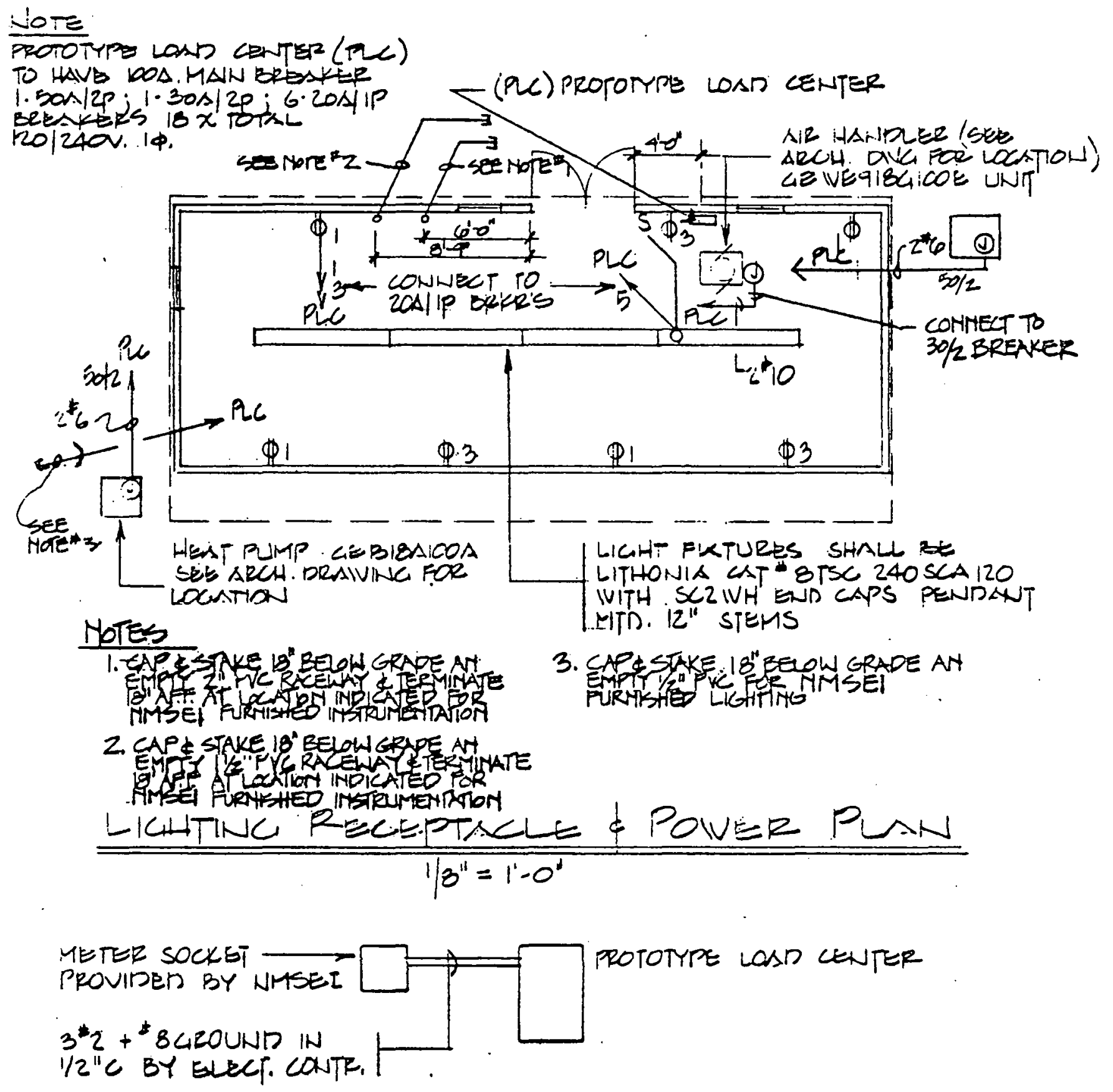

$$
\frac{\text { Electric Riser Diacrah }}{\text { no Scale }}
$$

\begin{tabular}{|c|c|c|}
\hline 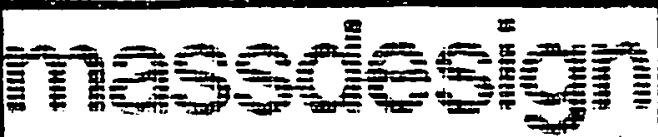 & $\begin{array}{l}\text { Job Na OS28 } \\
\text { Job Nom S.W. RES } \\
\text { G.E. SPACE DIVISIONY }\end{array}$ & Shoet No. \\
\hline 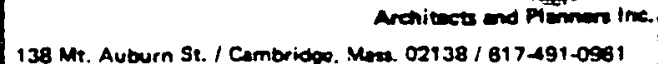 & Titlo ELEGRKAL RAN $\perp$ PAGRAM & \\
\hline 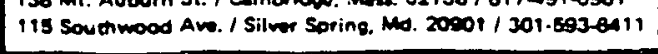 & Dato DEC 10,1480 & \\
\hline
\end{tabular}

Figure 2-36. Prototype Lighting Power Plan 


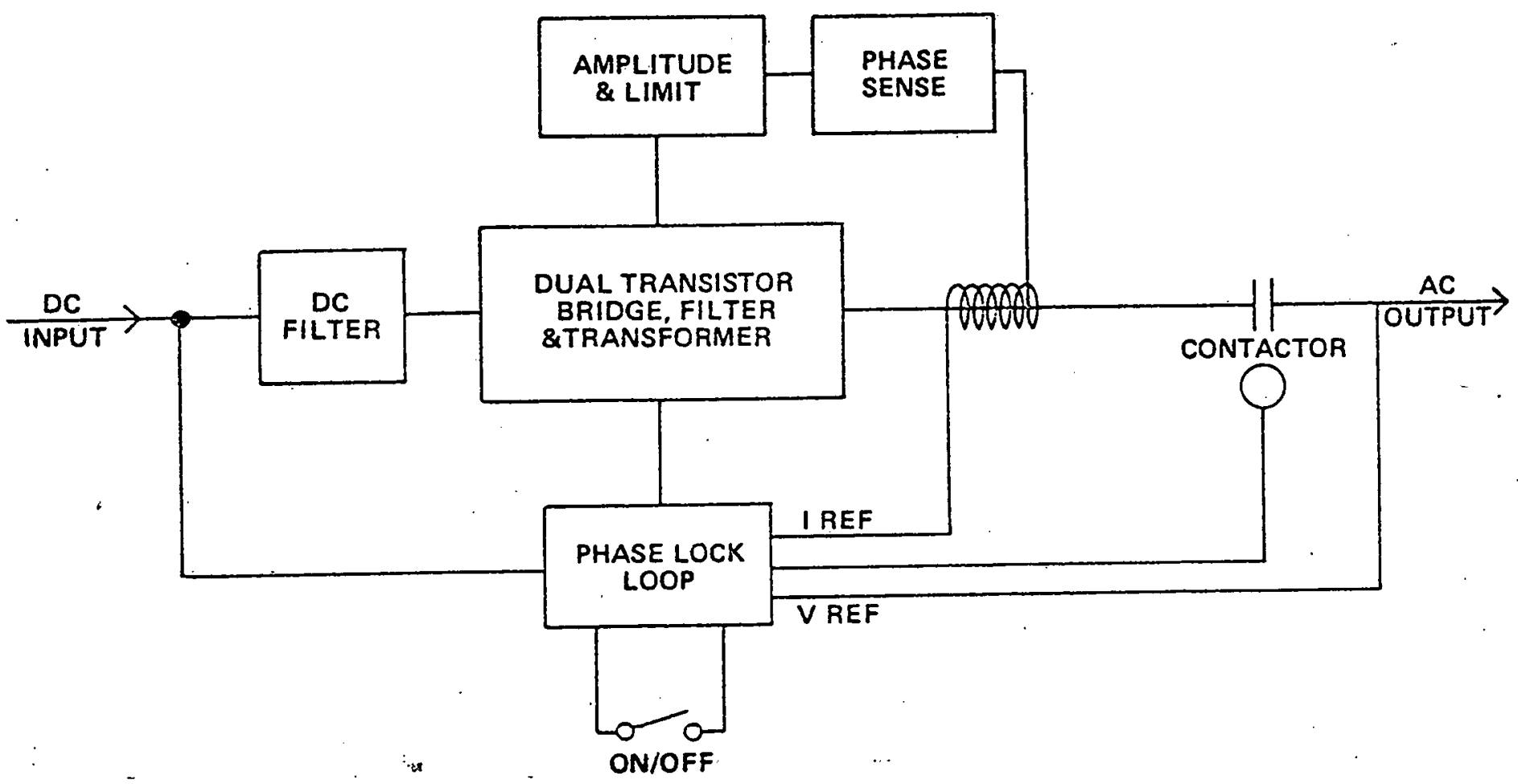

Figure 2-37. Inverter Functional Block Diagram.

There are three operating modes for the 763-4-200 Sunverter: Stand-Alone, Phaselock, and Utility. In the Stand-Alone mode, the unit supplies power to a connected load with locally adjustable frequency. For the Phaselock mode, output frequency is locked to that of the utility line. During operation in the Utility mode, the output is phaselocked to the utility line and voltage is locally adjustable to supply up to 6 kilowatts of power into the utility lines.

Were it available, maximum power tracking would permit operating the equipment at the maximum power point of the I-V curve of the connected solar array, with automatic start-up phaselock and line-tie features. The closed-1oop maximum-powercontrol algorithm originally supplied to the specification in Appendix $C$ did not function properly. Abacus then designed an open-loop algorithm that was ultimately implemented for the operational system. These two algorithms are described in Section 2.3.4.1 and 2.3.4.3. For completeness, the words in the text describe the closed-loop algorithm as originally specified; however, it should be noted that open-loop pilot cell option was implemented. 
- Nominal Rating

6-kW continuous operation; input $200 \mathrm{Vdc}$;

Output $240 \mathrm{Vac}$, single phase, $60 \mathrm{~Hz}$.

- Utility line voltage output control

- dc-to-ac transformer isolation

- Inverter operation enable/disable front panel switch control

- Automatic Operation enabled by switch and presence of utility vol tage within limits of $240 \mathrm{Vac} \pm 10 \%$ on output. Automatic operation disabled by switch or ac voltage outside limits

- Start automatic operation when enabled and input power exceeds operational tare loss

- Operate automatically to adjust the input voltage over the range of 160 to $240 \mathrm{Vdc}$ in response to pilot cell (reference cell) opencircuit voltage. Operate at the above range limits if the pilot cell commands operation beyond the range limits.

- Stop automatic operation when disabled or input does not exceed operational tare loss; automatic start shall be delayed $4 \pm 1$ minute following an automatic stop.

- Efficiency greater than $87 \%$ from $20 \%$ to full load

- Operational tare loss less than 250 watts

- Unity power factor

- Total harmonic distortion less than 5\%

- Safety features

- ac aud de "on" light

- input and output fuses

- manual reset on ac line loss

- internal temperature controlled fan with automatic over temperature lurnoff

Safety sircuits sense any improper current, phase, or voltage condition and cause shut down for any combination of circumstances which are potentially dangerous to the equipment. 
The majority of the circuitry is located on ten printed circuit modules and eight dual-bridge output power modules. The printed circuit modules are notched and keyed to prevent improper installation.

Because of the high efficiency of the 763-4-200, cooling fans are connected through thermal switches which turn the fans on during high ambient temperature conditions. Cooling air exits at the top of the unit. Estimates of the inverter performance are shown in Figure 2-38.

\subsubsection{Closed-Loop Maximum Power Tracking (Not Now Used)}

The inverter's control circuits are continuously powered as long as the utility line is energized. When the DC solar array voltage reaches 180 Volts, the following sequentially occurs: 1) a 5-Volt signal is sent to the Phaselock Loop, 2) the Maximum Power Tracking (MPT) is energized at a predetermined set point, and 3.) the AC line contactor is closed when the correct voltage and phase relationship are established. Under normal conditions, the MPT samples the AC output power through a sample-and-hold circuit. This insures the solar array is

- 10-kW ABACUS SUNVERTER

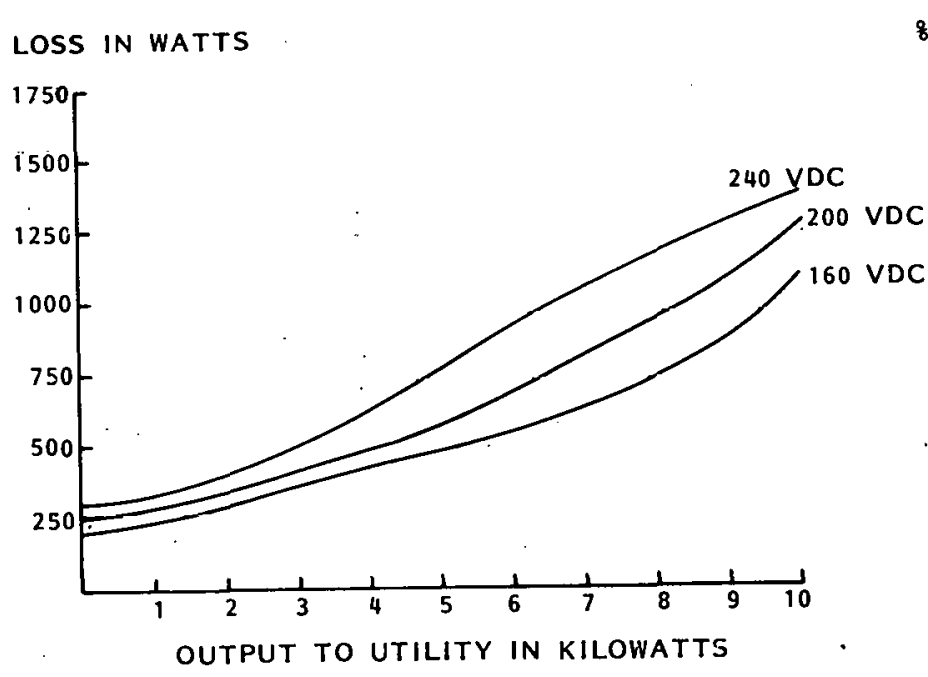

LOSSES
\& EFFICIENCY

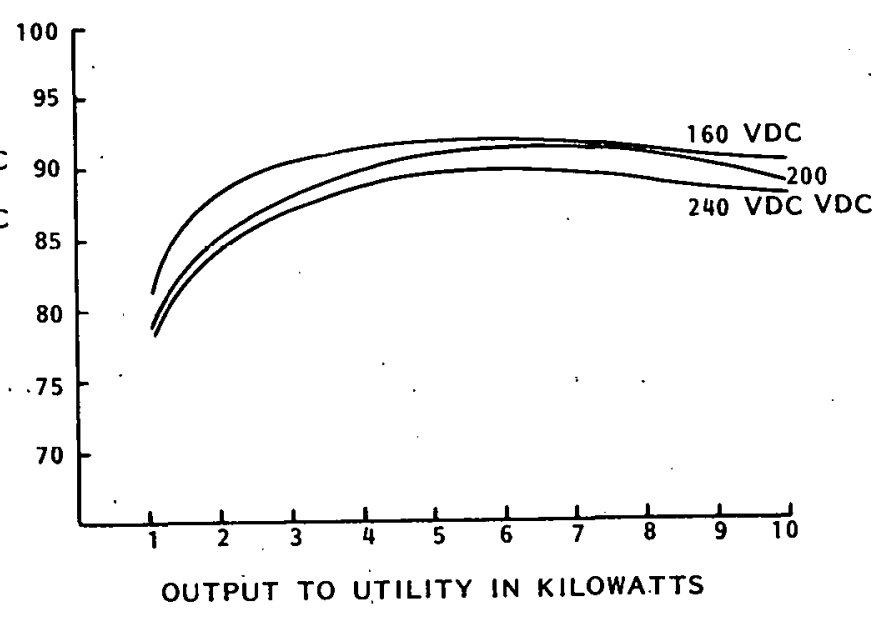

EFFICIENCY. 
operated at the optimum loading for maximum AC output power. Should the solar array output voltage exceed $240 \mathrm{VDC}$, the operating point for the array is shifted to a lower voltage level to limit the $\mathrm{DC}$ voltage to $240 \mathrm{~V}$. In a similar manner, if the $\mathrm{AC}$ output current were to exceed the rated value for the inverter (42 A to 240V), the operating point of the array would be shifted to a higher output voltage.

Should the DC array voltage fall below $160 \mathrm{~V}$, the AC line contactor will open and stay open for 4 minutes (to minimize unnecessary breaking and making of the contactor contacts). The AC contactor will close automatically after 4 minutes, if the array voltage has returned to $180 \mathrm{~V}$.

The following automatic disconnects are included features of the Abacus Sunverter: (1) For utility voltages greater than 264 VAC and less than 216 VAC, the inverter will disengage from the utility line; (2) also, for loss of utility power of phaselock, the inverter will be automatically disconnected from the utility line.

\subsubsection{Power Conditioner Users Controls}

The user controls for the unit includes a mode select switch, DC input power switch, an AC contactor switch and a reset switch. For this design, the mode select switch is set to the UTILITY position. Both the DC and AC switches must be on bus operation and the reset switch is used to restore the utility connection after being open.

Figure 2-39 shows the annual input voltage swing and operational power level for the inverter from the array as a function of the annual energy output. This data assumes Fil Paso weather conditions.

\subsubsection{Upen-Loop Array Voltage In Use)}

Due to operational problems in start-up, shutdown and during maximum power tracking, Abacus Controls developed an alternate algorithm for the unit control. It consists of a pilot cell that performs/ the double duty functions of insolation measuring during times when the Sunverter is off and as the reference to the array voltage control circuitry when the Sunverter is on. With the pilot cell, the complement of integrated circuits to accomplish both insolation sensing and 

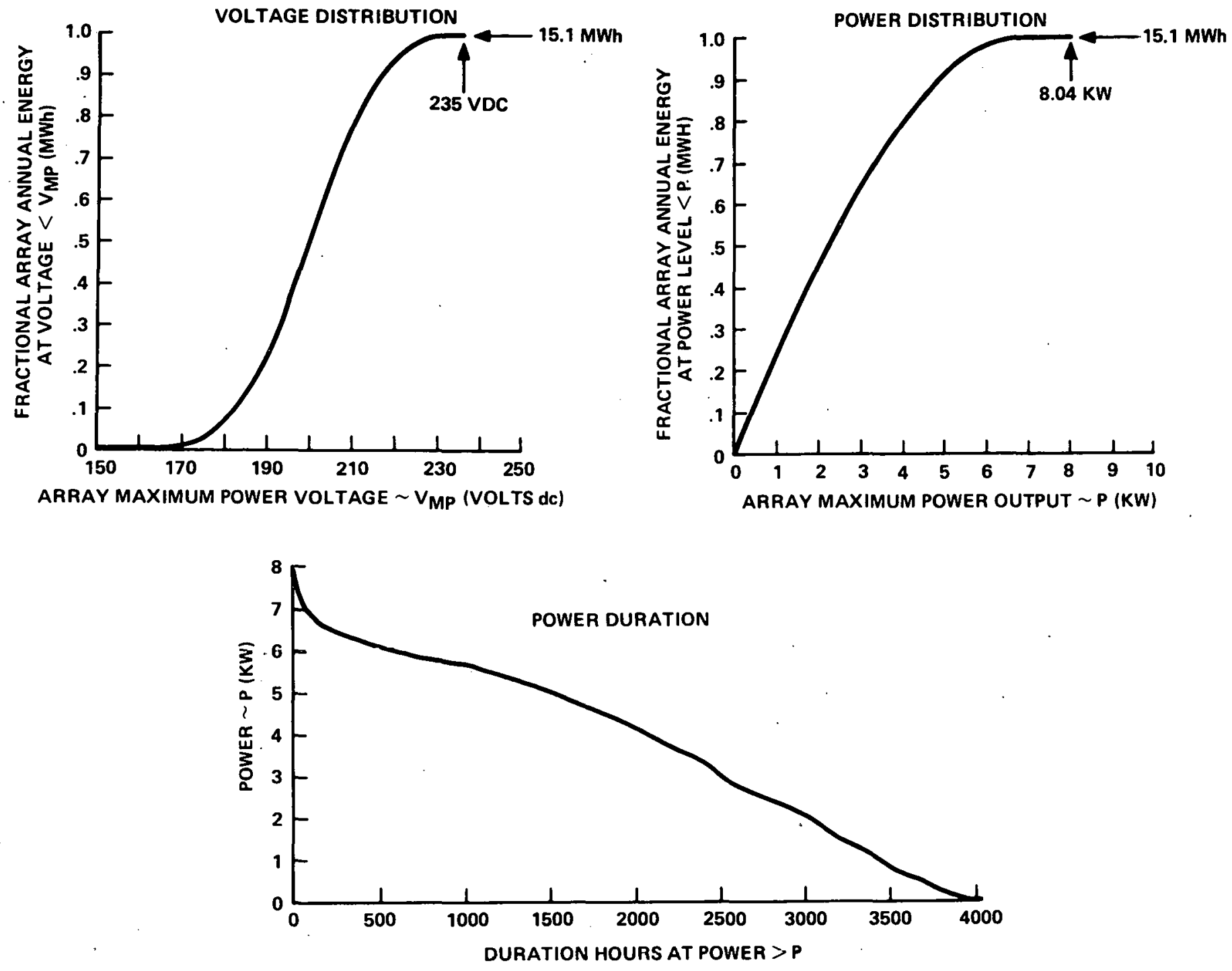

Figure 2-39. Estimated Annual Inverter Input Characteristics

array voltage control circuitry is four. Without the pilot cell, 24 integrated circuits and four power transistors on heat sinks are required to perform the two functions.

The voltage and insolation sensor provides a means of turning an Abacus Controls Sunverter on when there is sufficient power from the array on the roof. This is accomplished by shorting a pilot cell and measuring the short-circuit current. 
After the Sunverter turns on, the pilot cell is used to establish the open-circuit voltage of a typical cell on the roof. This, in conjunction with a small negative voltage, provides the approximate maximum power point signal to the Logic and Control Card in the Sunverter, which in turn determines the operating voltage of the array.

This option was incorporated into the GE Prototype in October 1981. 


\section{THIS PAGE}

\section{WAS INTENTIONALLY LEFT BLANK}


SECTION 3

PROTOTYPE FABRICATION HISTORY/LESSONS LEARNED

\subsection{MODULES}

\subsubsection{MANUFACTURE}

The PV shingle modules were fabricated by GE manufacturing personnel in a pilot production facility in Valley Forge, PA. This facility, Figure 3-1, which occupies $25 \mathrm{~lm}^{2}$ (2700 $\mathrm{ft}^{2}$ ) of floor area, was established to produce Block IVA shingle modules for use on the Northeast and Southwest Residential Experiment Station installations, on the JPL pre-production follow-on contract and future sales.

The Block IVA shingle module assembly procedure is outlined on the process flow diagram given in Figure 3-2. This sequence consists of ten distinct processing steps, which are described below:

1. Cell-to-Glass Bonding. Nineteen solar cells which are selected from the same current rating group are positioned, active-side up, on the bonding fixture. GE 534-044 is sprayed on as a uniformly thick coating over the active area of each cell and a clean glass coverplate is positioned by the fixture and placed in contact with the bonding pottant. The glass coverplate/solar cell assembly is allowed to cure at room temperature for at least eight (8) hours. A module serial number is assigned and written on pressure-sensitive tape which is placed on the front of the glass coverplate.

2. "P" Contact Soldering. The interconnector strips (2 per cell) are soldered to the rear side of the adjacent cell at three (3) places per strip as determined by the location of the solderable pads on the rear contact. The glass coverplate/solar cell assembly is inspected in accordance with the in-process acceptance/rejection criteria. Rework is performed based on the findings of this inspection and the accepted parts are placed in inventory to await the next processing step.

3. Rework-Cell Replacement. Defective solar cells shall be removed from the glass coverplate and replaced with cells from a current rating group which is at least as high as the original cells. Reworked glass coverplate/cell assemblies are reinspected.

4. Outer Skin Bonding. An outer substrate skin is placed in the final assembly fixture and coated with a layer of Silaprene adhesive. The glass coverplate/solar cell assembly is then placed in the fixture to make the overlapped bond between the skin and the coverplate. 

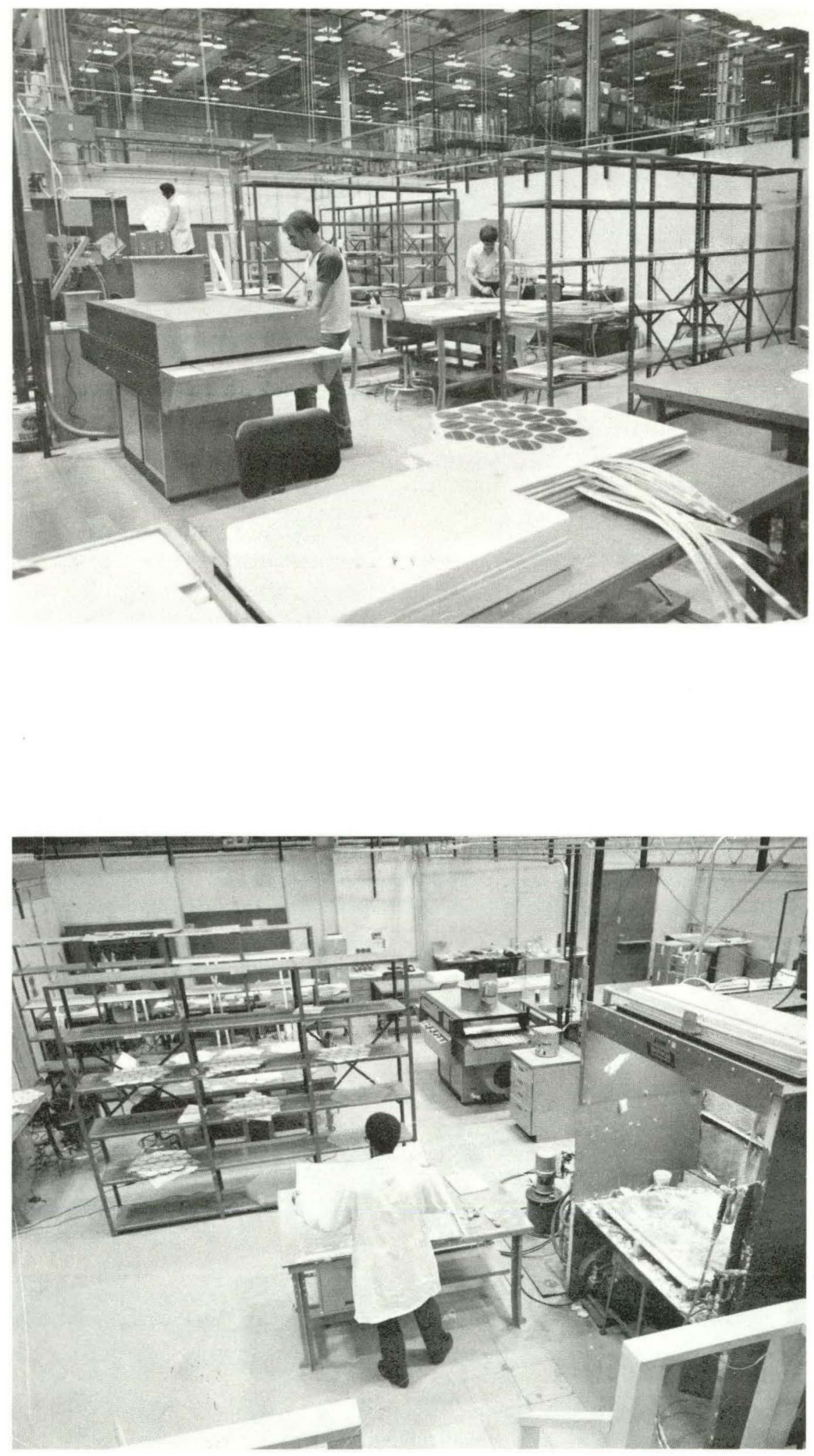

Figure 3-1. Block IV Shingle Module Manufacturing Facility 

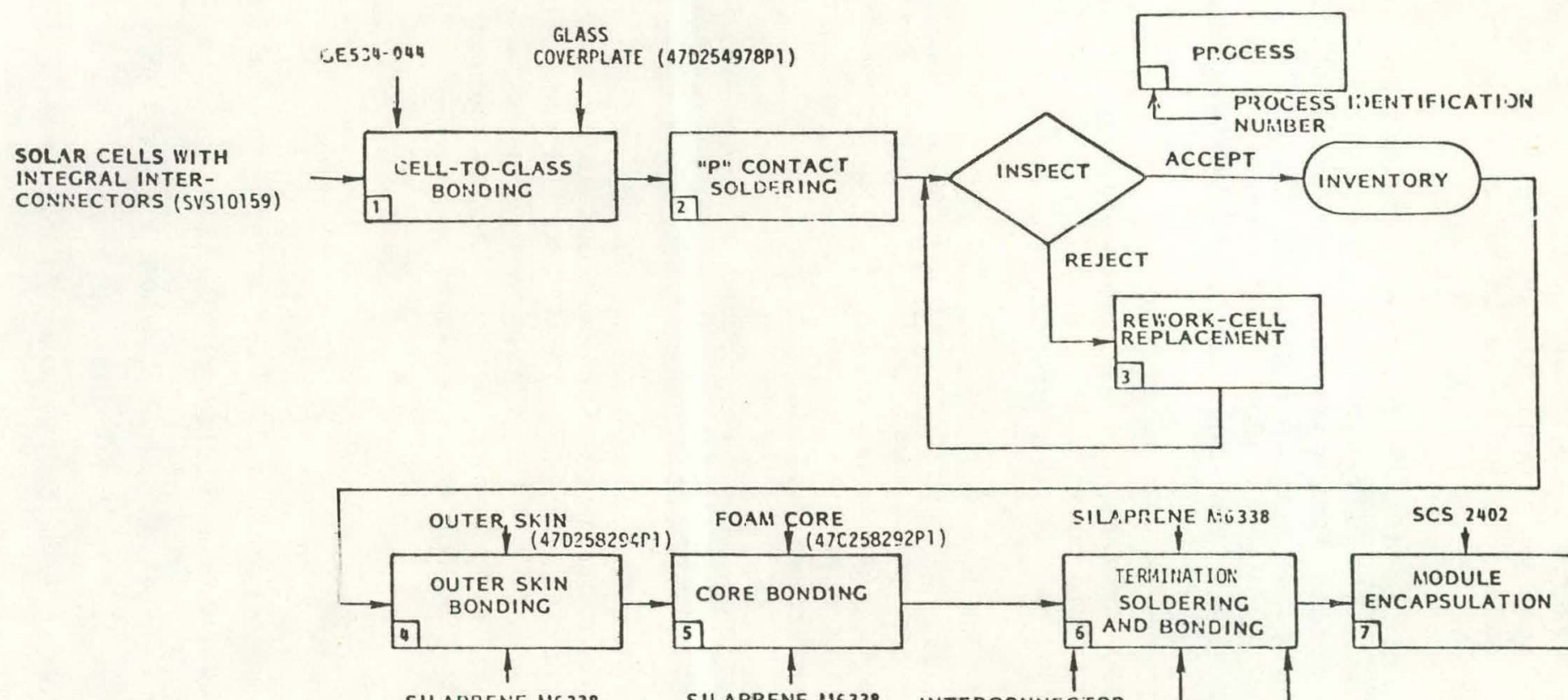

SILAPRENE 116338

SILAPRENE 1.16338 INTERCONNECTOR

(47B252771P1) POSITINE
STRIP

STRIP
4762532S2P1)

NEGATIVE

STRIP

(47B258282P2)

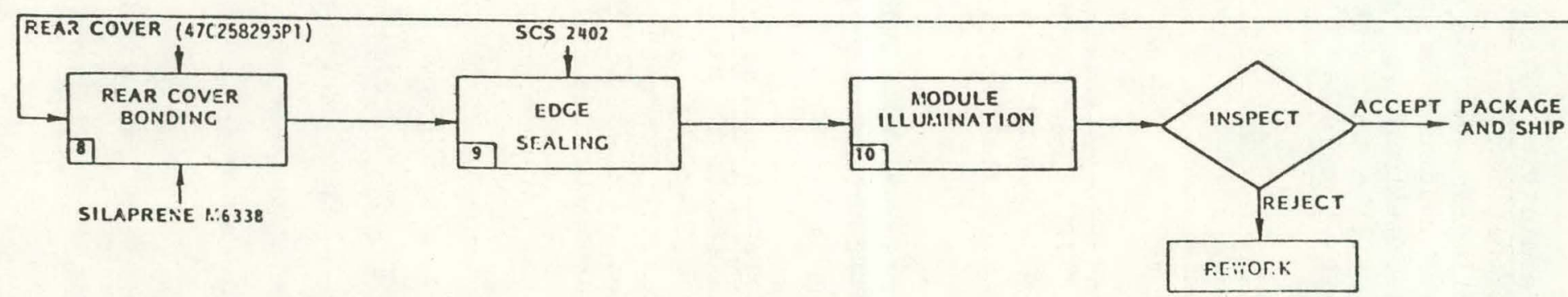

Figure 3-2. Block IV Shingle Solar Cell Module Process Flow Diagram 
5. Core Bonding. The substrate core is immediately placed in the final assembly fixture and rolled to achieve a bond between the skin and the top surface of the foam core. Silaprene adhesive is applied and spread over the rear surface of the core.

6. Termination Strip Soldering and Bonding. The two termination strip assemblies are positioned in the fixture on the top of the Silaprene-coated rear surface of the foam core. The termination strips are soldered to the cell circuit positive and negative terminals using two additional interconnector strips to make the connection at the positive end. The rear surfaces of the termination strips are coated with Silaprene.

7. Module Encapsulation. The rear surface of the glass coverplate/solar cell assembly is coated with GE 2402 construction sealant. The material is spread to cover the entire area with a uniform thickness to just cover the back of each solar cell.

8. Rear Cover Bonding. The back of the foam core is covered with a layer of Silaprene and the rear cover is positioned in the lamination fixture and weighted over its entire area. After two hours at room temperature, the bonded module is removed from the final assembly fixture and placed on a bench for at least 3 days of final curing.

9. Edge Sealing. The glass edges are sealed all around with GE 2402 and the outer substrate skin is marked with the serial number. This completes the module assembly.

10. Module Illumination. The I V characteristic for each module is measured on the LAPSS at the Optional Test Conditions (OTC). After conversion to the Standard operating Conditions ( $S O C$ ) the module output power at the Nominal Operating Voltage $\left(V_{n o}\right)$ is recorded in the serial number log and stamped on the module at the appropriate location on the outer substrate skin.

\subsubsection{SHIPPING}

The modules are shipped in wooden boxes approximately $1.2 \mathrm{~m}$ square and $\mathrm{lm}$ high. The box holds 45 modules packed with styrofoam fillers. The 375 modules were shipped in 9 boxes from Valley Forge to the site. Each box has a weight of $225 \mathrm{~kg}$ and must be loaded and unloaded by a fork lift. The boxes are stored at the site as shown in Figure 3-3. No protective cover from the weather is required.

No modules were damaged in the complete shipment process. The modules were shipped with an I V trace for each module. 


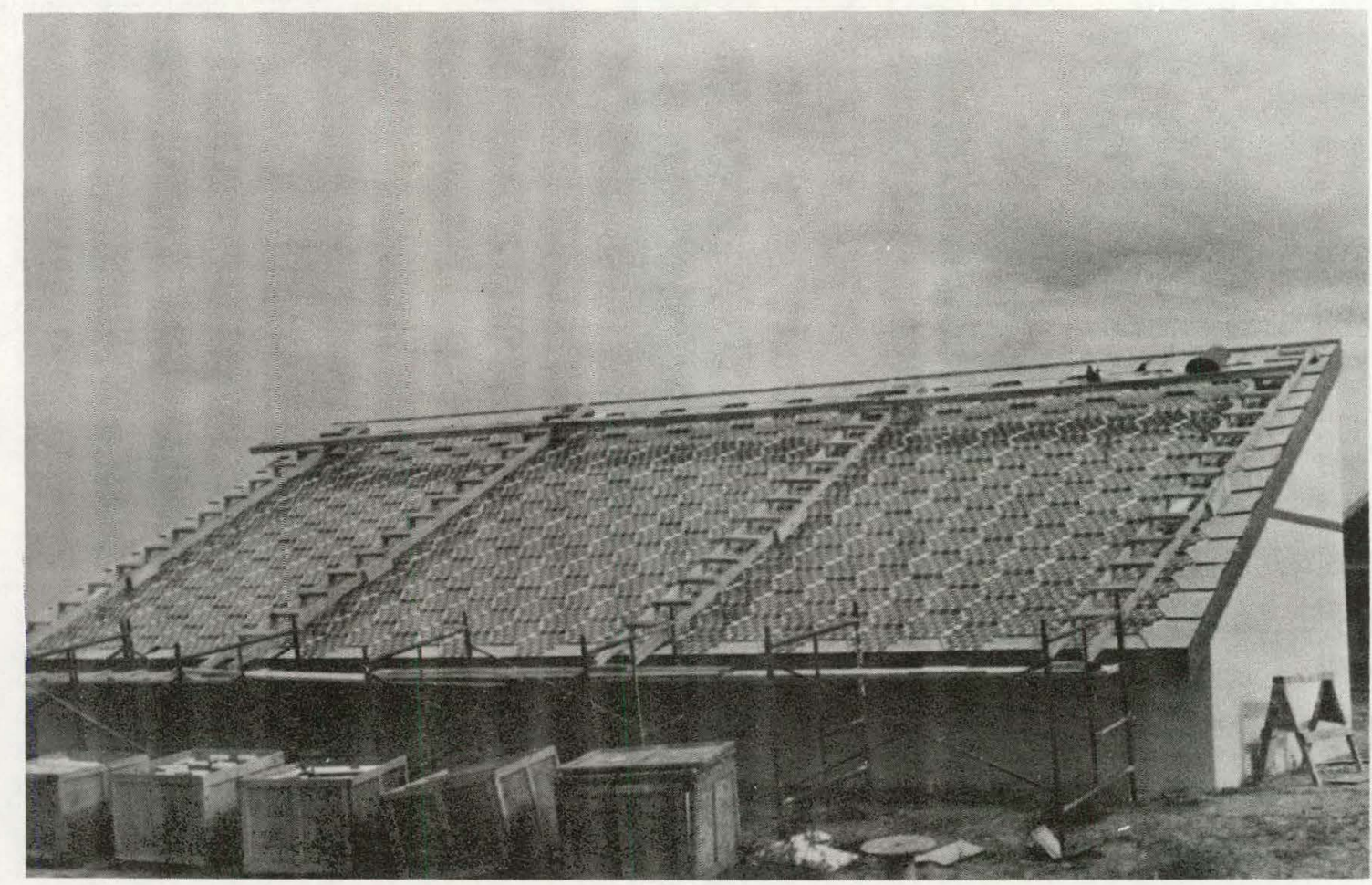

Figure 3-3. Shipping Boxes at the Installation Site 


\subsubsection{MODULE INSTALLATION}

The shingle installation and wiring were divided into several separate specific tasks. Tables 3-1 and 3-2 provide a breakdown of the labor hours required for each of these tasks. In Table 3-1, the actual shingle placement and nailing takes less than half the total labor time. Installation of the roof angles and caulking along the roof angles are tasks which may be eliminated in future installations. These labor savings reduce the module installation to 44 hours. The wiring labor hours total another 40 hours. No caulking of modules was performed as originally implemented at the Northeast RES since this was considered an unnecessary step.

Table 3-1. Array Installation Labor

\begin{tabular}{|rl|l|r|}
\hline \multicolumn{2}{|c|}{ Task Description } & Labor & Hours \\
\hline 1 & Staging - Scaffolding/Ladders & Carpenter/Laborer & 12 \\
2 & Active Shingle Placement and Nailing & Roofer & 24 \\
3 & Dummy Shingle Installation & Roofer & 8 \\
4 & Roof Angle Installation & Laborer/Carpenter & 12 \\
5 & Caulking & Laborer/Carpenter & 6 \\
\hline & TOTAL & & 62 \\
\hline
\end{tabular}

Table 3-2. Array Wiring Labor

\begin{tabular}{|cl|l|r|}
\hline \multicolumn{2}{|c|}{ Task Description } & Labor & Hours \\
\hline 1 & Layout FCC Wire & Electrician/Laborer & 12 \\
2 & Connect Module To FCC Runs & Electrician & 24 \\
3 & Wire FCC To THWN J-Box & Electrician & 2 \\
4 & Wire Outside Safety Switch & Electrician & 2 \\
\hline & TOTAL & & 40 \\
\hline
\end{tabular}

During the installation of the photovoltaic shingle system, several points became apparent which should be considered in planning for future installations to save labor hours. The first and most important of these in terms of reducing the 
installation cost is to educate the installing contractors in the photovoltaic shingle system prior to their placing bids. This may be best accomplished by giving the contractors an opportunity for "hands-on" contact with the shingle modules as well as a presentation via photographs or slides of the installation sequence. During this presentation, the durability and ease of installation of the shingle modules should be stressed. This education should be key in reducing the contractor's contingency in his bid.

The following points relative to the installation would be helpful to note:

1. What equipment and materials the contractor will be expected to supply should be clarified.

2. Average installation time for placing, nailing and crimping the Block IV shingles was 5 man min. per shingle.

3. The nailing and crimping procedure should be reviewed in detail using actual hardware.

The second area which should be considered in future shingle projects would be some means to accommodate scaffolding for the initial installation as well as future inspection and replacement. In the installations, scaffolding has been the most time-consuming and least-productive step. Future installations should consider integrating a support rail at the top and bottom of the roof into the building design. This rail could support a rolling ladder which could be removed and stored until needed for service.

In lieu of an integrated support system, the Northeast and Southwest arrays were installed using fiberglass or wood extension ladders supported on the ground at the bottom of the roof and on blocking at the top of the roof. Intermediate supports at mid-span were padded with styrofoam sheets. Ladder jacks supported scaffold planks spanning between the ladders. The installers used the planks to hold their position on the roof and work across the rows, however, most of their welght was supported by kneeling on the shingles. This is a good example of demonstrating the shingle durability. other interesting points with regard to durability include an instance during the Northeast installation when an installer accidentally dropped a hammer from the top of the roof which skidded 
down to the shingle faces to the ground without damaging the coverglass. In the Southwest, a worker on the ground threw a utility knife to a worker on the roof. The throw was short and the knife hit near the edge of the coverglass of a shingle module wi thout damage.

A third aspect to be considered in future installations is assisting the contractor in proper planning and sequencing of the installation. In the Northeast the installation was not accomplished in an orderly sequence and much time was wasted in switching from one task to another. In the Southwest, the step-by-step installation was followed (i.e., buses laid, shingles nailed and crimped) and the contractor spent $1 / 2$ the time on-site as compared to the Northeast installation.

Attaching the flat conductor buses to the roofing felt, until they are covered by the shingle modules, presented a mịnor problem. Duct tape was used for this purpose every six feet along the row. When the bus cables are installed first, they are exposed to weather for a time before being covered with shingles. This weathering, along with the fine aggregate which the manufacturer places on the roofing felt to keep it from sticking together in the roll, causes poor adhesion in the duct tape. Under moderate wind conditions, the bus cables can blow off the roof. It was necessary to staple the tape to the roof deck to hold the buses in place to remedy this problem. Also in attaching the bus cables to the roof, it is necessary to consider the spacing of the positive and negative shingle leads since the bus cable must be lifted slightly to make the crimp connection.

An additional area of note is in the proper spacing of the first row of shingles. In order to have the completed array centered on the roof the middle shingle of the first row should be placed one quarter of the shingle width off the center line. This is necessary due to staggered row-to-row spacing of the shingle modules.

Also to ensure proper coverage of the roof, the roof dimensions should be verified prior to starting the installation. This will avoid a situation which occurred in the Northeast where the roof was one foot longer than designed requiring an extra row of dummy shingles. 
A final area for consideration in future shingle systems which require installation of the flat conductor cable test leads would be the installation of a wireway running parallel to the roof rafters, flush with the roof deck and near the edge of the roof. This would provide a space for the test lead beneath the shingles and would not create the lump which now occurs. Using asphalt shingles as dummies and the wireway to carry the test leads and main bus cables, the fiberglass angle trim along the roof rake could be eliminated.

\subsection{POWER CONVERSION SUBSYSTEM}

\subsubsection{MANUFACTURE/PROCUREMENT}

The power conversion subsystem was purchased as a complete unit according to the specification listed in Appendix C from Abacus Controls, Inc. of Sommerville, N.J.

\subsubsection{SHIPPING}

The unit was shipped from N.J. to the site by the vendor. The unit was tested and accepted by GE personnel at the manufacturing plant in N.J. prior to shipment. The unit was not damaged during shipment.

\section{$3 \cdot 2 \cdot 3$ INSTALLATION}

The actual installation of the unit was minimal since it is floor mounted and requires only 4 wire connections plus a ground. The tasks for completing the remainder of the system installation are listed in Table 3-3 along with the labor hour estimates. These estimates were provided by Interstate Electrical Services, the system installer. Note that running wiring in conduit is a major labor contributor.

\subsection{SYSTEM}

\subsubsection{FINAL CHECKOUT PROCEDURE}

A final checkout procedure was developed to verify system operation. The procedure is strictly related to the experimental nature of the installation, although many steps are applicable on a mature installation. The procedure also covers the requirements of the System Acceptance Plan developed by NMSEI. 
Table 3-3. Power Conditioner Installation and Wiring Labor

\begin{tabular}{|lllr|}
\hline \multicolumn{1}{|c}{ Task } & \multicolumn{1}{c|}{ Description } & Labor & Hours \\
\hline 1 Mounting & Mount Boxes \& Panels & Electrician & 8 \\
2. Wiring & $\begin{array}{l}\text { Wire from DC Safety Switch to } \\
\text { Inverter and from AC Panel to } \\
\text { Inverter }\end{array}$ & Electrician & . \\
TOTAL & & & \\
\hline
\end{tabular}

\subsubsection{Installation Complete Status}

The first step is to verify that all wiring and connections have been checked for proper installation and continuity. All circuit breakers and switches should be in the open/off position. The programmable load box should be in an off condition with the main AC disconnect closed. Utility power should be supplied to the prototype load center loads (lighting, outlets, space conditioning, etc.)

\subsubsection{On/Off Sequence}

The status of the utility line should be checked with an oscilloscope prior to the turn-on sequence. The existence of voltage spikes, high harmonic content or other undesirable attributes should be noted, both with and without other site PV systems operating, and corrected if possible before turn-on. A preferred state for turn-on is to have all other site PV systems off at the time the system is first turned on, or at least systems on the same single-phase utility transformer turned off. This condition will expedite the isolation of faults among systems, if any faults develop from utility line interactions. Recheck the line after turn-on to note any changes created by turn-on.

From the installation-complete status, the turn-on sequence can be initiated. Refer to Figure 2-34 for the appropriate switches referenced in this sequence.

1. Close the circuit breaker in the AC Power Panel Box.

2. Close the $A C$ contactor coil switch on the inverter. Set the inverter dials to the utility position and auto position.

3. Close the external DC disconnect after checking that ground connection is on. Close the internal DC disconnect. 
4. Close the DC switch on the inverter. The indicator light on the inverter should come on if there is 80 VDC from the array.

The Over Voltage/Under Voltage (OV/UV) light should come on at $80 \leqq$ VDC $\leqq$ 160. If the $\mathrm{DC}$ voltage $190>\mathrm{V}$, the inverter should turn on over a 15second period, and the phase lock light will go on (an audible hum will be produced).

5. Normal system ON/OFF control can be exercised by the circuit breaker in the AC Power Panel, leaving all other switches in the operational position. The system will not turn on with the throw of this circuit breaker unless the DC voltage is less than 240 and greater than $190 \mathrm{~V}$.

\subsubsection{Module Test}

Each module was flash tested prior to shipping.

\subsubsection{Array IV Trace}

An array IV trace should be taken at the positive and negative array leads. MIT/Lincoln Laboratory supplied the electronic load and $x-y$ plotter and conducted the test. Figure 3-4 shows an actual IV trace of the array taken during checkout.

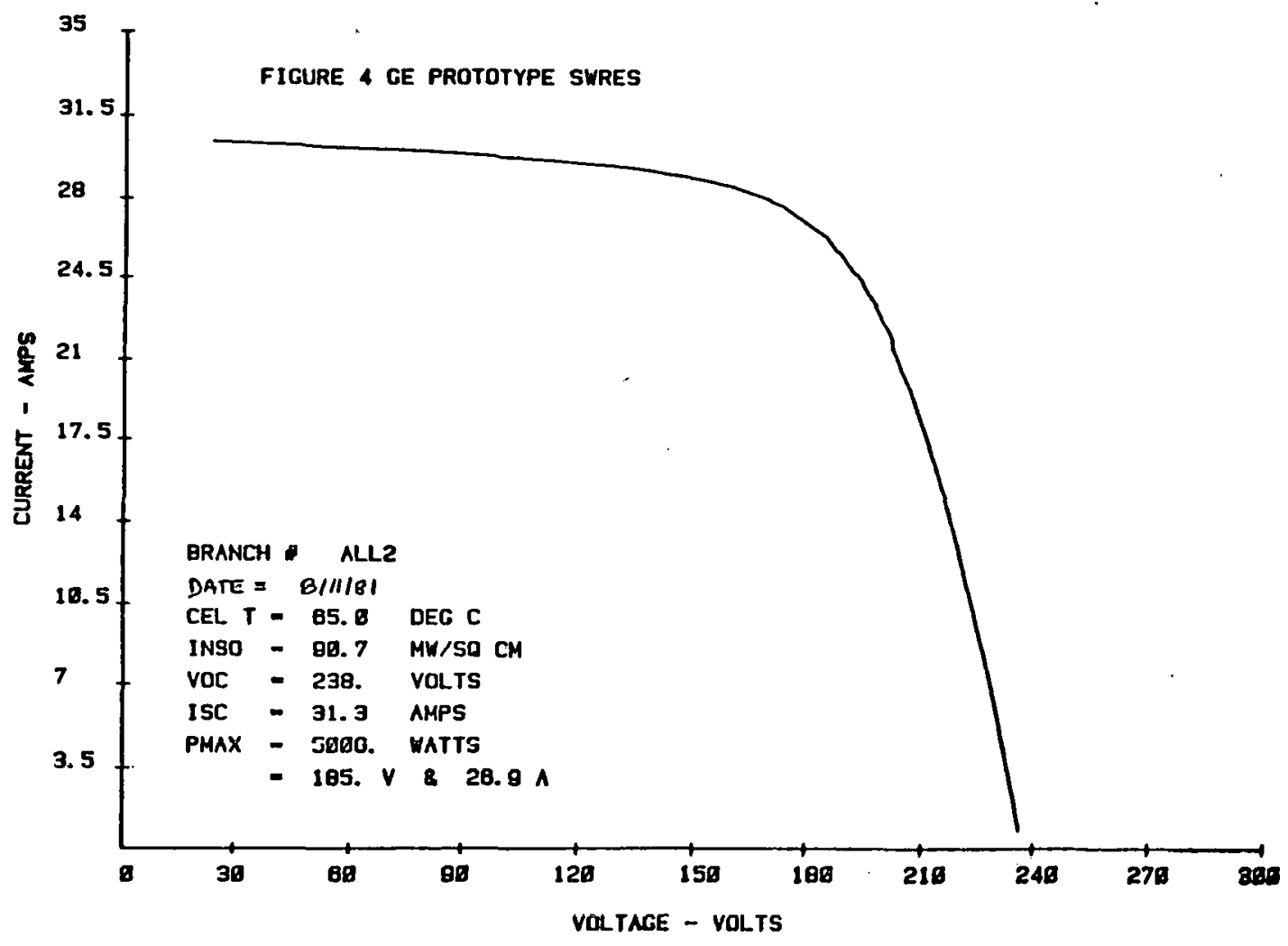

Figure 3-4. Actual Array IV Checkout Trace 
The array output slightly exceeded initial predictions. Under peak power rating conditions $\left(100-\mathrm{mW} / \mathrm{cm}^{2}\right.$ insolation with $25^{\circ} \mathrm{C}$ cell temperature) the array maximum power is $6.7 \mathrm{~kW}$. Under Normal Operating Conditions (NOC) the maximum power output is $5.4 \mathrm{~kW}$ assuming an NOCT of $68^{\circ} \mathrm{C}$.

\subsubsection{Power Conversion Subsystem}

Subsystem checkout included the following items:

1. Automatic sunrise startup and sunset shutdown.

2. 8-hour normal operation at greater than $50 \%$ rating at some time during operation.

3. Maximum-power-point-operation verification.

4. Utility interruption shutdown.

During the checkout procedures several problems were encountered with the Abacus unit. The predominant problem centered on the unit's inability to track maximum power. Instead the unit operated at a constant voltage around $160 \mathrm{~V}$. Upgrading of the component modules failed to provide correct unit operation. Abacus ultimately supplied a new power tracking module using a pilot cell input. This is an: open-loop control scheme and may not be considered to be the commercial answer to the maximum-power-tracking problem.

GE then provided a pilot cell to be used for the experimental tracking technique. The pilot cell was a single 100-mm SOLEC International cell similar to the ones used in the shingle modules. Successful operation was eventually achieved. with these modifications.

\subsubsection{OPERATION AND MAINTENANCE PROCEDURES}

\subsubsection{Module Failure Detection/Location}

The highly redundant series/parallel network of shingles precludes the observation of only a few defective modules. Several modules would have to be defective to detect problems with the IV trace. Since this is an experimental system, wire leads from each series row of FCC were mun into the prototype structure and 


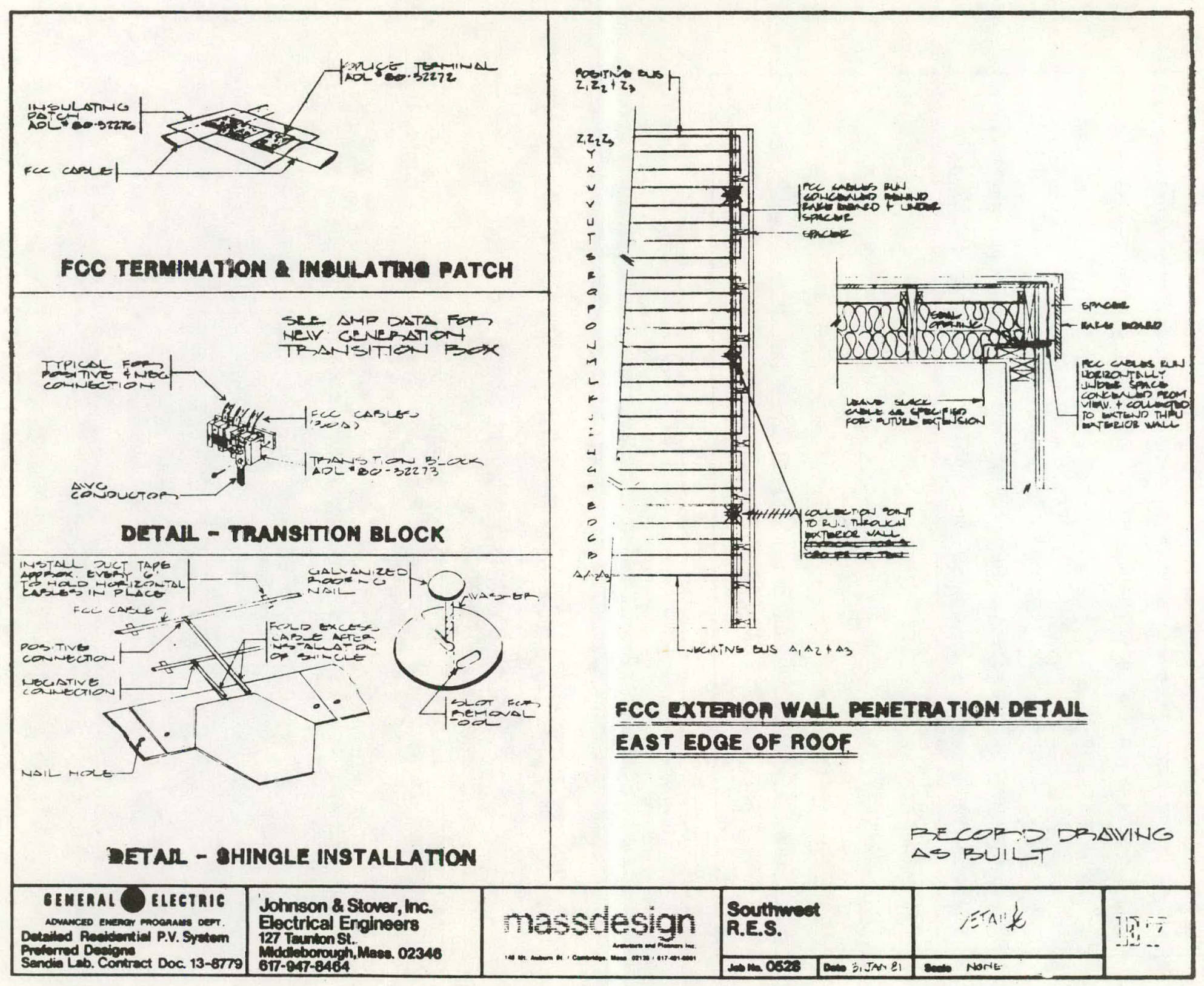

Figure 3-5. FCC Runs for Diagnostic Procedure 
Table 3-4. Diagnostic Procedure for Defective Modules

1. Under maximum power system operation, measure row-to-row voltage to isolate row(s) with significant mean row voltage deviations.

2. Check suspect row performance by measuring row short circuit current. A measured reduction in row short circuit current provides an indication of the number of suspect modules in that row.

3. Visually inspect modules in row for damaged cells.

4. Verify or locate single module in row by shading a single module at a time and repeating short circuit test looking for little or no change in current output.

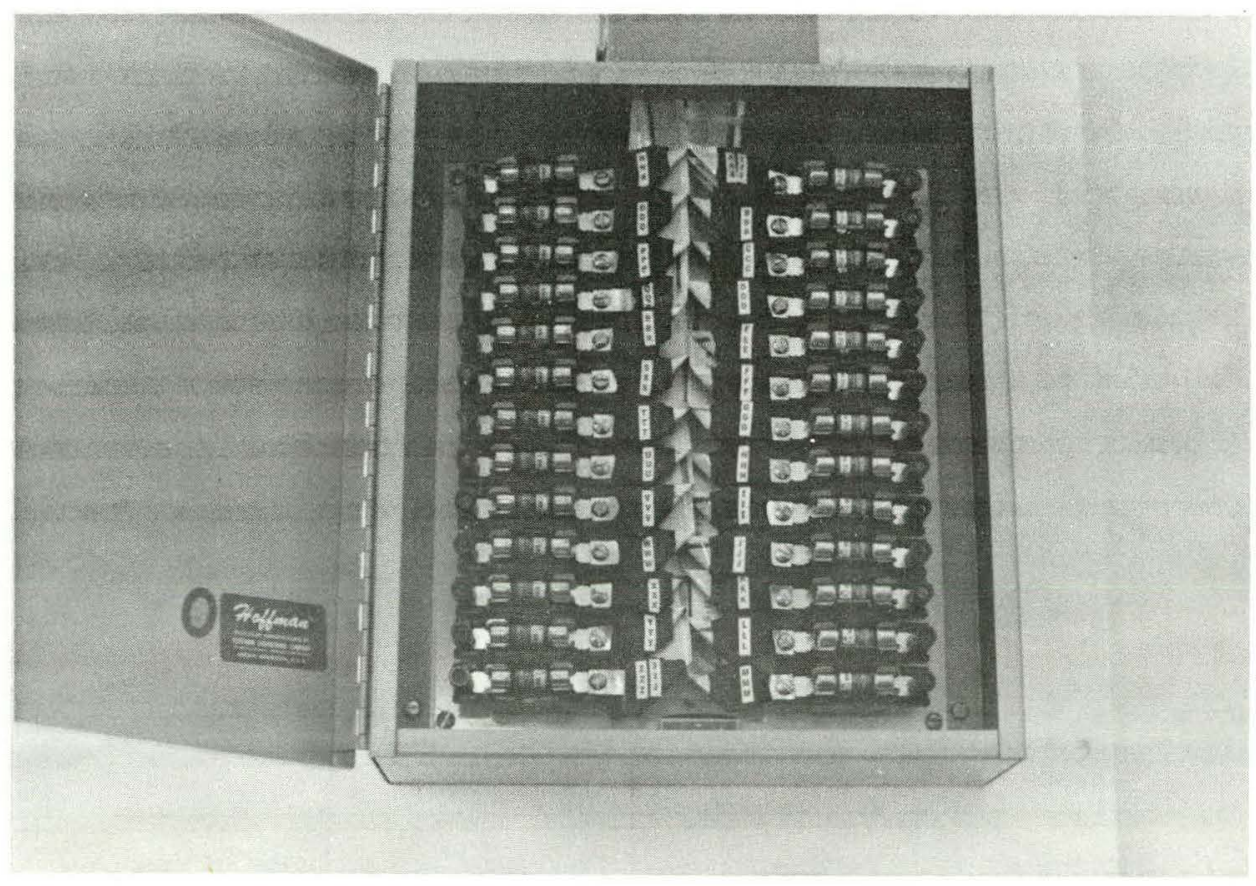

Figure 3-6. FCC Terminal Box for Diagnostic Procedures 
terminated in a panel box as shown in Figure 3-5. Figure 3-6 shows an actual panel box. If questionable performance is suspected, the procedure listed in Table 3-4 would be followed.

A module identified as having little or no change in short-circuit current on the row characteristics as it is shadowed is probably defective. The module should be removed and an IV flash test made to compare performance with the pre-installed performance data supplied with the module. This leads to an initial determination of whether the problem is in the module or with the FCC leads. All short-circuit current tests should be limited to short durations.

\subsubsection{Module Removal/Replacement}

Access to the affected module can be achieved by using ladders, similar to the installation procedure. Table 3-5 lists the step-by-step procedure.

Removal of the defective module can be accomplished by first placing a wedge beneath the glass coverplate of the modules on either side of the affected module in the course directly above. The split washer removal tool is inserted to remove the washers under each of the two nail heads. At this point the defective module can be lifted up so that the nailheads clear the thickness of the substrate and can be pulled out to the extent of the FCC length. The two FCC's are cut at the exit point from the module substrate to remove the module from the roof. A new module can be connected to the FCC ends remaining from the old module by using a splice crimp connector to make the butt joints. The nail head should be lifted slightly while the module is out with a pair of pliers or a nail pry bar. The new module can then be reinserted in the roof over the old nailheads. It is then necessary to reinsert the split washers on the replacement module to be adequately hold it down again. The removal tool can be used to reinsert the washers.

\subsubsection{Normal Operation}

Normal system ON/OFF control can be accomplished by the circuit breaker in the AC power panel, leaving all other switches in the operation position. If utility loss occurs, the inverter reset switch must be depressed and then the $A C$ contactor must be rethrown to the "on" position. 


\section{$3 \cdot 3 \cdot 3$ COST INFORMATION}

Table 3-6 summarizes the system installation data. The numbers are normalized to a system peak power rating of $5350 \mathrm{~W}$. The labor dollars assume a $\$ 15 / \mathrm{hr}$ rate. The array module installation labor can be reduced by eliminating the application of caulking and the roof angles, which saves $5 k / w_{p}$ of costs. These two items also are significant contributions to the module installation material costs resulting in a $6 \notin / W_{p}$ savings if eliminated.

The module and inverter costs are high since they both represent the first units produced.

Tables $3-7,3-8$ and $3-9$ present the detailed material cost data for array installation, array wiring and system installation respectively.

Table 3-5. Module Replacement Procedure

- Lift adjacent modules to expose nails on defective module

- Remove Washer

- Lift Module over roofing nails

- Extend FCC cable fold

- Cut FCC cable leads

- Position new module

- Interconnect FCC leads with splice connector and insulate

- Lift nail heads

- Align module in place

- Reinsert washers 
Table 3-6. Summary of System Costs

\begin{tabular}{|c|c|c|}
\hline Description & Hours & $\begin{array}{l}\text { Actual costs } \\
\$ \$ W_{p}(1)\end{array}$ \\
\hline $\begin{array}{l}\text { Array } \\
\text { Modules } \\
\text { Installation } \\
\text { Labor (5) } \\
\text { Materials } \\
\text { Wiring } \\
\text { Labor } \\
\text { Materials } \\
\text { Roofing Credit } \\
\text { Power Conditioning } \\
\text { Inverter (4) } \\
\text { System Installation } \\
\text { Wiring } \\
\text { Labor } \\
\text { Materials }\end{array}$ & $62 \mathrm{hrs}$. & $\begin{array}{c}\$ 35.50 \\
0.17(2) \\
0.09(3) \\
0.11 \\
0.17 \\
(0.13) \\
\\
2.29\end{array}$ \\
\hline
\end{tabular}

NOTES

(1) Maximum power $5350 \mathrm{~W}$ at NOCT

(2) Eliminating roof angle installation, labor saves $\$ 0.05 / \mathrm{w}_{\mathrm{p}}$

(3) Eliminating roof angles saves $\$ 0.06 / \mathrm{w}_{\mathrm{p}}$

(4) Per peak array power, not inverter rating

(5) Assumes $\$ 15 / \mathrm{hr}$ average rate

Table 3-7. Array Installation Materials List

\begin{tabular}{|c|c|c|c|}
\hline T. tem & Description & Quantity & Cost \\
\hline * 1. Sealer & Silicone Caulk & 5 tubes & $\$ 20.00$ \\
\hline $\begin{array}{l}\text { 2. Fasteners } \\
\text { (bolts, screws, } \\
\text { clips, etc.) }\end{array}$ & $\begin{array}{l}\text { Roofing Nails, } \\
\text { Washers }\end{array}$ & $\begin{array}{r}5 \# \\
750\end{array}$ & $\begin{array}{l}\$ 2.00 \\
\$ 128.00\end{array}$ \\
\hline * 3. Flashing & $3 " \times 3 " \times 1 / 4 "$ Fiberglass & $100 \mathrm{ft}$. & $\$ 325.00$ \\
\hline Special Hardware & Scuffuld Rental & 1 wk & $\$ 20.00$ \\
\hline TOTAL & & & $\$ 495.00$ \\
\hline $\begin{array}{l}\text { Displaced Roofing } \\
\text { Materials }\end{array}$ & $\begin{array}{l}\text { Asphalt Shingles (320\#) } \\
\text { Roofing Nails }\end{array}$ & $\underset{20 \#}{9-1 / 3 \mathrm{sq} .}$ & $\begin{array}{l}\$ 700.00 \\
\$ 8.00\end{array}$ \\
\hline
\end{tabular}

* May be omitted in future installation. 
Table 3-8. Array Wiring Materials List

\begin{tabular}{|l|c|c|c|}
\hline \multicolumn{1}{|c|}{ Item } & Description & Quantity & Cost \\
\hline 1. Wire & a) \#6 Cu. THHN (Transition Block & $24^{\circ}$ & $\$ 4.00$ \\
& to External Disconnect) & $360^{\circ}$ & $\$ 180.00$ \\
b) \#10 FCC (t and - Busses) & $960^{\circ}$ & $\$ 480.00$ \\
c) \#I2 FCC (24 runs @ 40') & 1 & $\$ 50.00$ \\
2. Junction Boxes & I-Convert from FCC to THWN & 1 & $\$ 120.00$ \\
3. Conduit & Safety Disconnect (Outside) & $10^{\circ}$ & $\$ 3.00$ \\
4. Other & I" EMT & 750 & $\$ 75.00$ \\
& Insulating Patches & & 3.00 \\
\hline Tape for FCC & & $\$ 911.00$ \\
\hline
\end{tabular}

Table 3-9. Power Conditioner Installation and System Wiring Materials List

\begin{tabular}{|l|l|c|c|}
\hline \multicolumn{1}{|c|}{ Item } & \multicolumn{1}{|c|}{ Description } & Quantity & Cost \\
\hline 1. Wire & \#8 THN & $100^{\circ}$ & $\$ 30.00$ \\
& $\# 14$ THWN & $50^{\circ}$ & $\$ 5.00$ \\
2. Conduit & $3 / 4^{\prime \prime}$ PVC Conduit \& Connector & $50^{\circ}$ & $\$ 12.50$ \\
& I" Liquid Tite Conduit $^{\circ}$ & $16^{\circ}$ & $\$ 20.00$ \\
3. Junction Boxes & Varistor J-Box/Cover & 1 & $\$ 4.00$ \\
& Inside Safety Switch & 1 & $\$ 110.00$ \\
& House Panel & 1 & $\$ 120.00$ \\
4. Other & Lightning Arrester & 1 & $\$ 17.50$ \\
& Varistor GE \#V2752A40B & 1 & $\$ 12.00$ \\
\hline
\end{tabular}


SECTION 4

REFERENCES

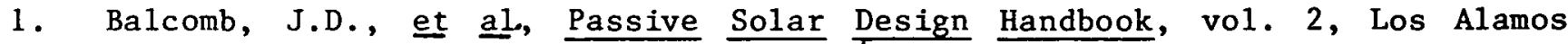
Scientific Laboratory, University of California, Department of Energy Report DOE/CS-0127/2, January 1980.

2. General Electric Company, Final Report - Analysis and Design of Residential Load Centers, SAND 80-7017, October 1981 .

3. General Electric Company, The Design of a Photovoltaic System for a $\underline{\text { Southwest }}$ Al1-Electric Residence, SAND 79-7056, February 1980.

4. General Electric Company, Design and Fabrication of Prototype Systems for Photovoltaic Residences in the Northwest, GE Document No. 81AEP-4, November 1981 . 


\section{APPENDIX A \\ INSTALLATION SAFETY NOTES FOR \\ PHOTOVOLTAIC SHINGLE MODIRES}




\author{
INSTALLATION SAFETY NOTES \\ FOR \\ PHOTOVOLTAIC SHINGLE MODULES
}

WARNING

EXERCISE CPAUTION IN HANDLING AND INSTALLING PHOTOVOLTAIC SHINGLE MODULES. THESE MODULES ARE ELECTRICAL POWER SOURCES AT ALL TIMES WHEN EXPOSED TO ANY LIGHT LEVEL. HAZARDOUS ELECTRIC POTENTIALS EXIST AT THE EXPOSED TERMINALS OF INTERCONNECTED MODULES UNDER ANY LIGHT LEVEL CONDITIONS.

NORMAL FULL SUNLIGHT CAPACITY:

PHOTOVOLTAIC MODULE

$\begin{array}{lc}\text { OPEN CIRCUIT VOLTAGE } & 10 \text { VOLTS DC } \\ \text { SHORT-CIRCUIT CURRENT } & 2.5 \text { AMPS DC } \\ \text { MAXIMUM POWER RATING } & 7.2 \mathrm{~V}, 2.25 \mathrm{~A} .\end{array}$

ROOF ARRAY (25 SERIES COURSES OF 15 PARALLELED MODULES PER COURSE) OPEN-CIRCUIT VOLTAGE 235 VOLTS LC SHORT=CIRCUIT CURRENT $\quad 37.8$ AMPS, DC

MAXIMUM POWER RATING $\quad 180 \mathrm{~V}, 34 \mathrm{~A}$.

SEE PAGE A-2 FOR RECOMMENDED SAFETY PROCEDURES 


\section{SAFETY NOTES}

Safety precautions must be enforced for all personnel that have access to the shingle modules and roof array. Each module generates electrical potentials similar to the levels available at the terminals of a standard 12-volt automobile battery. The series connection of modules up the slant height of the roof will generate electric potentials comparable to those of the normal residential utility 240-volt line service. The photovoltaic module electric potentials are always present under any light level. Safe handling and installation procedures must insure that no conductive path is provided across shingle module or roof installation terminals by any personnel or equipment. The procedures listed below should be followed during module installation:

\section{SAFETY PROCEDURES}

1. Instaliation should proceed only during dry weather on a completely dry roofing surface.

2. No metal ladders or scaffolding or other conductive equipment capable of spanning exposed terminals should be used.

3. The array negative ground terminal should not be connected until the electrical installation is complete.

4. The modules should be installed one course at a time from roof edge to roof edge, and not in any staggered pattern which provides exposure to series connected modules. Each termination must be suitably insulated as it is completed.

5. No electrically conductive material should be laid over the roofing surface.

6. The installation should be accomplished working from the felt roof surface as much as possible.

7. Grounded components, such as plumbing vent pipes, gutters, etc., should not be touched by personnel during the installation process. Ground potential and other conductive components should be covered with an electrical insulating cover during the installation process.

8. Care should be exercised not to make physical contact with module terminations across a series multiple of installed angles. 
APPENDIX B

ELECTRICAL SYSTEM INSTALLATION

SPEC IFICATIONS 


\title{
ELECTRICAL SPECIFICATIONS
}

FOR

GENERAL ELECTRIC COMPANY

Southwest Residential

Experimental station

New Mexico Solar Energy Institute

Las Cruces, New Mexico

\author{
Prepared by \\ JOANSON \&TOVER, INC. \\ 127 Taunton street \\ Middleborough, Massachusetts 02346
}

Revised January 31, 1981 
ELECTRICAL SPECIFICATIONS

FOR

GENERAL ELECTRIC COMPANY

INDEX

PART 1: GENERAL REQUIREMENTS

$\begin{array}{lll}1.1 & \text { GENERAL } & \\ 1.2 & \text { REFERENCES } & \mathrm{A}-1 \\ 1.3 & \text { SCOPE OF WORK } & \mathrm{A}-1 \\ 1.4 & \text { WORK NOT INCLUDED } & \mathrm{A}-1 \\ 1.5 & \text { QUALITY ASSURANCE } & \mathrm{A}-1 \\ 1.6 & \text { PRODUCT DELIVERY, STORAGE, HANDLING } & \mathrm{A}-2 \\ 1.7 & \mathrm{~A}-2 \\ 1.8 & \text { TEMPTRICAL CHARACTERISTICS } & \mathrm{A}-2 \\ 1.9 & \text { RECORD DRAWINGS } & \mathrm{A}-3 \\ 1.10 & \text { SAFETY PRECAUTIONS } & \mathrm{A}-3 \\ \end{array}$

PART 2: PRODUCTS

2.1 RACEWAYS AND FITTINGS A-4

2.2 SUPPLEMENTARY STEEL, CHANNEL, AND
SUPPORTS

2.3 CONDUCTORS A-5

2.4 SAFETY SWITCHES A-5

2.5 GROUNDING SYSTEM A-5

2.6 PANELBOARD A

2.7 PHOTOVOLTAIC EQUIPMENT A-8

\section{PART 3: EXECUTION}

3.1 WORK COORDINATION AND JOB OPERATIONS A-9

3.2 PLANS AND SPECIFICATIONS A-9

3.3 SYSTEM IDENTIBICATION A-9

3.4 WORKMANSHIP AND INSTALLATION METHODS A-9

3.5 ARRAY ERECTION PROCEDURE A-10

3.6 FCC CABLE INSTALLATION A-11

3.7 ELECTRICAL SERVICES A-12 


\section{RESIDENTIAL PROTOTYPE PHOTOVOLTAIC ELECTRICAL}

\section{INSTALLATION SPECIFICATIONS}

\section{PART 1: GENERAL REQUIREMENTS}

1 . 1 GENERAL

A. This Specification includes all electrical work to install a roof-mounted photovoltaic (PV) system at Residential Experimental Unit at the New Mexico Solar Energy Institute's Southwest Residential Experimental Station at Las Cruces, New Mexico.

B. Construction of the prototype unit including interior lighting and power systems will be performed under another contract. This specification is for the array installation and interconnection only.

C. The system consists of several types of shingles of the GE block IVA design which are to be interconnected by means of AMP Industries-type FCC flat conductor cable. All shingles, FCC cables, and the necessary interconnectors, splice packs, and installation tools for use on FCC cable will be furnished to the contractor by General Electric Company. The inverter package will also be furnished to the contractor by General Electric Company.

\section{2 REFERENCES}

A. Cooperate and coordinate all electrical work with other contractors on site.

B. The complete structure of the prototype will be constructed under another concurrent contract. The roof will be constructed and covered with roofing felt ready for shingle installation.

1.3 SCOPE OF WORK

A. Provide all labor, materials, equipment, and supervision necessary to complete the electrical work associated with a roof-mounted photovoltaic. (PV) system, including al1 equipment identified.

\subsection{WORK NOT INCLUDED}

A. Utility service from the New Mexico Solar Energy Institute power panel to the house panel will be provided by the New Mexico Solar Energy Institute. 
B. Construction of prototype structure including roof underlayment and roofing felts.

C. Prototype interior electrical work including lighting fixtures, wiring devices, and mechanical equipment connections is to be performed under another contract.

\subsection{QUALITY ASSURANCE}

A. The work shall be executed in strict conformity with the latest edition of the National Electric Code and all local regulations that may apply. The installation of type FCC cable on a roof is not covered under Article 328 of the present National Electrical Code. The installation of the FCC cable shall be performed in strict accordance with manufacturer's recommendations and in accordance with the best practices of the trade. In case of conflict between contract documents and a governing code or ordinance, the more stringent standard shall apply.

B. Unless otherwise specified or indicated, materials and workmanship shall conform with the following standards and specifications (latest edition):

1. National Electric Code.

2. Occupational Safety and Health Act.

3. Standards of Underwriterg' Laboratories (UL).

4. National Fire Protection Association (NFPA).

5. National Electrical Safety Code.

6. Local codes.

C. Carry out tests, secure permits, pay fees, and arrange for all inspection of regulatory agencies for work under this Section.

1.6 PRODUCT DELIVERY, STORAGE, HANDLING

A. All equipment, upon receipt, shall be inspected for damage and shall then be stored and protected from damage until project completion.

\subsection{ELECTRICAL CHARACTERISTICS}

A. The PV array will produce an output of approximately 180 volts DC, which will then be inverted to a nominal voltage of $120 / 240$ volts, single phase. Capacity of the system is approximately $6 \mathrm{KW}$. 
A. Provide temporary electricity from the prototype load center as required to allow completion of the work. Remove any temporary wiring when no longer required.

\subsection{RECORD DRAWINGS}

A. Maintain two (2) copies of the documents on site and record any revisions on one set of the job progresses. At project completion, transfer all changes to the other set.

B. Maintain a $\log$ of any difficulties encountered during the installation and the steps taken to resolve same.

\subsection{SAFETY PRECAUTIONS}

A. The contractor shall be completely responsible for all safety precautions to be taken by installers of the array. Refer to Appendix A, PV Module, and Installation Safety Notes.

B. The contractor shall also comply with the "Integrated Safety Plan, Southwest Residential Experiment Station" issued by NMSEI SW RES Site Manager. 


\subsection{RACEWAYS AND FITTINGS}

\section{A. Conduit - General}

1. No conduit shall be used smaller than 3/4" No conduit shall have more than four (4) $90^{\circ}$ bends in any one run, and where necessary pull boxes shall be provided.

2. Rigid PVC conduit shall be Schedule 40 UL listed for $90^{\circ} \mathrm{C}$. All fittings shall be solvent connected. Provide threaded fittings where connected to metallic boxes. PVC conduit shall be Carlon. PVC conduit shall be used for exterior work and for raceways enclosing ground conductors.

3. Thin wall conduit (EMT), zinc-coated steel, conforming to industry standards shall be used for all interior raceway systems. Fittings for EMT shall be compression or set-screw type. EMT shall be equal to Pittsburgh Standard Conduit Company, Republic steel Tube, or Youngstown Sheet and Tube Company.

4. Conduit Fittings
a. Insulated bushings shall be provided on all raceways larger than $3 / 4^{\prime \prime}$.
b. Access fittings shall be Type LL, LR, or LB as required, and shall be equal to Appleton, Cróuse-Hinds, or RACO.

B. Outlet, Pull, and Junction Boxes

1. Each outlet box shall have sufficient volume to accommodate the quantity and size conductors entering the box in accordance with the requirements of the National Electric Code. Outlet boxes shall be pressed steel as manufactured by steel City, RACO, or Appleton.

2. Pull boxes or junction boxes shall be constructed of code gauge sheet metal of a size not less than required by the National Electric Code, if no size is indicated on the drawings, and shall have hinged doors. 
2.2 SUPPLEMENTARY STEEL, CHANNEL, AND SUPPORTS

A. Furnish and install all supplementary oteel, channel, and supports necessary for the proper mounting and support of all equipment. Provide minimum of $3 / 4$ " thick plywood backboards for mounting of all equipment at the equipment area.

B. All supplementary steel, channel, and supports shall be UL approved, be galvanized steel, and be as manufactured by Steel City, Unistrut, Power Strut, or Kindorf.

\subsection{CONDUCTORS}

A. All conductors shall be stranded copper of the size indicated on the drawings. All conductors shall be Type THWN rated $90^{\circ} \mathrm{C}$ for dry locations and $75^{\circ} \mathrm{C}$ for wet locations.

B. Conductors for use on the DC aystem shall be color-coded red for positive and black for negative. AC conductors shall be color-coded black for Phase A, red for Phase B, white for Neutral and green for Ground. DC conductors shall also be identified as DC by label markers.

C. All conductor terminations shall be made up by standard lug connections on equipment having same. Terminations made up for attachment to positive or negative transition blocks at the roof and the DC input inductor or other devices not having standard'lugs shall be bolted type compression lugs as manufactured by Burndy, Thomas

$\&$ Betts, or Panduit of tinplated copper. Bolts shall be $1 / 4-20$ silicon bronze.

D. All terminations, other than those located within enclosures, shall be insulated.

\subsection{SAFETY SWITCHES}

A. Safety switches shall be general duty 2-pole or 3-pole fused or non-fused in NEMA 1 or NEMA $3 R$ enclosures as indicated on the drawings and shall be capable of being padlocked. Switches shall be equal to General Electric, Westinghouse, or Square $D$.

\subsection{GROUNDING SYSTEM}

A. There shall be four (4) isolated ground systems as follows: 
1. Grounded Neutral: The house panel neutral shall be grounded only at the house panel by means of a \# 8 AWG connection between the panel neutral bus and the panel ground bus. The panel neutral block shall be isolated from the panel enclosure. A \#8 AWG green insulated ground conductor shall then interconnect the panel ground block to the house ground bus.

2. Equipment. Ground: A \#8 AWG green insulated ground shall be looped between all equipment and shall be connected to each piece of equipment by means of a ground lug on the equipment. This conductor shall terminate at the house ground bus.

3. Varistor Ground: The \#14 AWG green insulated ground conductor from the Varistor shall be connected through a separate conduit system with the array negative ground. This ground shall terminate at the house ground bus.

4. Array Negative Bus Ground: Provide a \#8 AWG green insulated ground condictor from the line side of negative bus terminal at the exterior mounted overcurrent device to the house ground bus.

Varistor ground.

Run in PVC raceway along with

5. House Ground Bus: Provide a 12" long 1/8" $x$ " copper ground bus on standofe insulators 12 " above the floor below the AC panel. There shall be four (4) ground connections to the bus as follows: \#8 AWG ground-to-house panel ground bus, \#8 AWG ground to equipment ground system, \#8 AWG ground at array negative bus, and \#14 AWG ground for Varistor gouunding. Provide a \#8 AWG ground from the bus to the utility service ground located at the utility service main disconnect. In addition, provide a \#8 AWG ground to a driven 3/4" $x 10^{\circ}$ long Copper Weld ground rod. This ground rod shall be located within the equipment area and shall extend 4" above the final floor location.

6. Varistor Surge Protection

a. Furnish and install a Varistor for surge protection, which shall be mounted in a junction box sized as required on the drawings. The junction box shall be provided with an insulated mounting block and terminal bar isolated from the metal structure. A \#14 AWG ground wire shall be tap-connected to the positive DC conductor which is to be protected by means of 
Burndy Servit-type KS split-bolt connector. This connector shall be insulated by taping. The load side \#14 AWG ground from the varistor shall be interconnected to the house ground bus.

b. Varistor on the positive DC side of the inver-. tor shall be General Electric catalog number V275 LA4OB.

B. Furnish and install a General Electric Lightning Arrester nippled to the side of the house service panelboard. Unit shall be catalog number TLP 175 and shall be connected with black leads to line buses and white to ground.

\subsection{PANELBOARD}

A. A panelboard in accordance with the following shall be provided. The House Service Panelboard is to be fed both from the AC output of the inverter and the New Mexico Solar Energy Institute power panel.

B. Panelboard shall be dead-front, safety-type, equipped with single or multi-pole circuit breakers, and shall be suitable for the voltage characteristics of the system; $120 / 240$ volts, single phase, three wire.

C. Buses may be copper or aluminum. Panelboard shall have a circuit directory card mounted in a frame with plastic cover installed on the inside of the door. Directory cards shall be properly filled in, using a typewriter. Panelboard shall be provided with a separate ground bus.

D. All circuit breakers shall be of quick-make, quickbreak type on manual operation, trip free, and with inverse time characteristics. All multi-pole breakers shall have an overload element in each pole so designed that an overload in one pole automatically causes all poles to open.

E. Panelboard cabinets shall be made of code gauge steel, surface-mounted, and shall be ordered without knockouts. Wiring gutters shall not be less than 4" wide.

F. Panelboard trims shall be made of code gauge steel, surface type. Door shall be eugipped with flush catch and lock.

G. Panelboard shall be General Electric type NLAB or approved equal. Breaker THQB bolt-on. SYM. INT. capacity 10,000 amps at 240 volts. 
A. The photovoltaic equipment including all shingle modules as shown on the drawings and including the roofing nails and split washers will be provided by Ge neral Electric Company.

B. The inverter package which forms an integral part of the generating and conversion system will be provided by General Electric Company and ahall be installed by the Electrical Contractor.

C. FCC Cable system: The FCC cable, splice connectors, insulating patches, and crimping tool will be as manufactured by AMP Industries and will be furnished by General Electric Company for installation by the Electrical Contractor.

D. Upon receipt of this equipment, each of the several parts shall be carefully examined to identify any possible shipping damages. 


\subsection{WORK COORDINATION AND JOB OPERATIONS}

A. Be responsible for all equipment necessary for erection of the roof array including staging. Commencement of array erection signifies acceptance of the surface upon which the shingles are to be installed.

B. Coordinate all work prior to commencing with all existing conditions of the structure.

\subsection{PLANS AND SPECIFICATIONS}

A. The drawings showing layout of equipment, especially within the equipment area, show a suggested layout. Carefully check dimensions of all equipment and make any adjustments necessary to accommodate any variations.

B. Post the schematic diagram and equipment plan and elevation at a reduced scale under glass in the equipment area.

\subsection{SYSTEM IDENTIFICATION}

A. Provide screwed-on phenolic nameplates (black with white engraving) on all equipment. Differentiate between $A C$ and $D C$ equipment.

B. All raceways enclosing DC conductors shall be identified by appropriate 1 abe 18 .

\subsection{WORKMANSHIP AND INSTALLATION METHODS}

A. All work shall be installed in a first-class manner consistent with best current trade practices. All materials and equipment shall be securely installed plumb and/or level.

B. The inverter cabinet shall be mounted usiug Korfund vibration pods. All wiring connections to this cabinet shall be in flexible metal conduit.

C. All raceways shall be properly aligned, grouped, and supported at right angles to or parallel with the principal building members.

D. Any holes drilled through structure shall be neatly made and properly sealed after equipment installation. 
E. All wiring in panelboard and enclosures shall be neatly formed and grouped.

F. Be responsible for all safety precautions and rubbish removal. Leave site in clean condition.

\subsection{ARRAY ERECTION PROCEDURE}


array layout. The array, therefore, shall be oriented to start at the right side of the roof when facing the array from the front. The excess roof area at the left side shall be covered by dumm shingles as indicated on the erection procedure on drawing E-4. These dummy shingles shall then be cut flush with the left edge of the roof.

B. It is recommended that the type FCC cable rows be secured to the roofing felts in their proper alignment prior to commencing erection of the shingles. Dimensions of FCC cable rows detailed on drawing E-3 are to cable center lines and are given exactly to the height each shingle row will advance up the roof. The connection of the shingle positive and negative leads allows some variation in the exact loaction of the cables. The cable row dimensions are identified so as to clear all nail holes.

C. The positive and negative leads of the shingles shall be connected to the horizontal FCC cable rows prior to nailing the ohingles in place. Nailing of the shingles shall be done by means of the nails and split washers provided. The opening in the washer shall be oriented in a straight vertical position to allow future removal of the shingle with the shingle removal tool. After the shingles have been secured in place, a bead of clear silicone sealant shall be applied to the bottom edge of the Hex to prevent shingles lifting during wind conditions. The leads on the singles are of sufficient length to allow removal of the shingle and reinstallation of a new shingle should it become necessary. After the ohingle has been electricalig connected and secured in place, the excess lead length shall be folded over on itself as indicated on Drawing $\mathrm{E}-7$.

D. The positive and negative buses each consist of three (3) runs of FCC cable. The negative leads from the first row of "SCM" shingles and the positive leads of the top active row of "SCM" shingles shall be connected to the three runs of FCC cable by alternating between the three rows. Shingles $1,4,7,10$, and 13 are to be connected to one cable; $2,5,8,11$, and 14 to the second cable; and $3,6,9,12$, and 15 to the third cable. 
E. The positive and negative buses shall be brought down through the roof approximately $16^{\prime \prime}$ down from the peak and $2-1 / 4^{\prime \prime}$ in from the edge. They shall pass between the rake and the exterior wall surface in a $11 / 4$ " diameter raceway sleeve from the roof to the top of the transition block enclosure. They shall then enter the top of the transition block enclosure and be terminated. Seal raceway openings in the transition block enclosure with Ducseal. Arrange enclosure to drain. All cables, including the positive and negative buses, extend over the right-hand side of the roof for diagnostic testing purposes. See details on drawings.

F. After all shingles are in place; install metal angle trim at both sides and ridge metal trim.

\subsection{FCC CABLE INSTALLATION}

A. The horizontal and vertical rows of FCC cables shall be secured to the roofing felt by means of duct tape approximately every $6^{\prime}$.

B. The positive and negative buses each consist of three (3) rows of FCC cable which shall be installed on top of each other. Tape the cables together periodically prior to securing to the roof.

C. Terminations and splicing shall be carried out in accordance with the manufacturer's recommended procedures. Special connector assemblies will be provided along with an installation crimping tool. The operation of the crimping tool is such that a positive connection is ensured prior to release of the tool jaws. Each splice or connection shall be insulated by means of a manufactured two-piece insulating patch.

D. The transition blocks will be provided by General Electric as part of the FCC cable package. Two transition blocks will be required and shall be mounted by the Electrical Contractor in an appropriately sized NEMA $3 R$ hinge cover enclosure on the exterior of the prototype. The hinged cover enclosure shall be provided by the Electrical contractor.

E. All horizontal runs of FCC cables shall be extended over the right-hand side of the roof between the exterior wall and the rake. They shall then rua within the rake space to collection points as indicated on the drawings.

At the collection points they shall be extended into the prototype. A minimum of $6^{\circ}$ of 8 lack cable shall be left at the collection point. 
Each cable shall be marked with the row designation indicated on the drawings. Openings through the exterior wall of the prototype shall be sealed with Ducseal.

The cable running between the rake boards and the exterior wall shall be tucked up into the space so as not to be visible from the exterior and so as not to be exposed to the weather.

The installing contractor shall quote a separate price for terminating these cables on stud type terminals within NEMA enclosures with 12 AWG leads connected to each cable and extended to a terminal board in NEMA enclosure to be located at the New Mexico Solar Energy Institute instrumentation area within the prototype.

\subsection{ELECTRICAL SERVICES}

A. The utility service will be provided by New Mexico Solar Energy Institute from the local utility company source and will terminate in a panelboard called the New Mexico Solar Energy Institute Power Panel. The Electrical Contractor shall provide an empty 1-1/2" PVC raceway extension from a raceway stubbed below grade to a main disconnect switch mounted on the exterior of the building. This disconnect switch will be provided by NMSEI. Provide $11 / 2 "$ conduct between this disconnect switch and the interior junction box as indicated on the drawings. The wiring between the main switch, meters, NMSEI power panel, and prototype load center will be provided by NMSEI.

B. The House Service Panel shall be provided by the Electrical Contractor. It has no direct loads connected to it. It serves as the interface between the PV system and the New Mexico Solar Energy Institute Power Panel. It shall receive its $120 / 240$ volt, 10,3 -wire source of supply from the New Mexico Solar Energy Institute Power Panel. The inverter output shall be terminated at the panel through the circuit breaker indicated.

C. The Electrical Contractor shall provide an empty 2" PVC raceway extension from a raceway stubbed 18 " A.F.F. by the prototype contractor Into the New Mexico Solar Energy Institute furnlshed data box. 
APPENDIX C

ABACUS CONTROTSS SUNVERTER

SPECTFICATIONS 


\begin{tabular}{|c|c|c|c|c|c|}
\hline \multicolumn{2}{|c|}{ APPLICATION } & \multicolumn{4}{|c|}{ REVISIONS } \\
\hline NEXT ASSY & USFD ON & LTR & DESCRIPTION & DATE & APPROVED \\
\hline
\end{tabular}

\section{SUHVERTER SPECIFICATIOISS}

IMPUT

1. Input is from a photovoltaic array with or without a battery.

2. Input DC voltage range is 200 to $300 \mathrm{VDC}$.

2.1 Automatic startup at 220VDC.

2.2 Automatj.c turn-off at 200VDC.

2.3 Autornatic turn-off at 300VDC.

3. Ripple current returned to utility: $2 c^{4}$ rms of DC current.

\section{OUTPUT}

Noninal output is 24 OVAC $50 \mathrm{~Hz}$ Single Phase.

4. Utility intortie

4.1 Two-wire 24OVAC (utility supplies neutral for $1.20 \mathrm{~V} / 120 \mathrm{~V}$ ).

4.2 Output current. is phaselocked to utility voltage, resultine in unity power factor.

4.3 Output current is.amplitude regulated with amplitude set by internal calibrated adjustment or sienal from the max power track module.

4.4 Harmonic distortion of the current into the utility is $5 \%$ THD.

4.5 futomatic disconnect if utility voltage is less than 2l6VAC.

4.6 Automatic disconnect if utility voltage is greater than 2614 VAC.

4.7 Automatic disconnect if current exceeds rating.

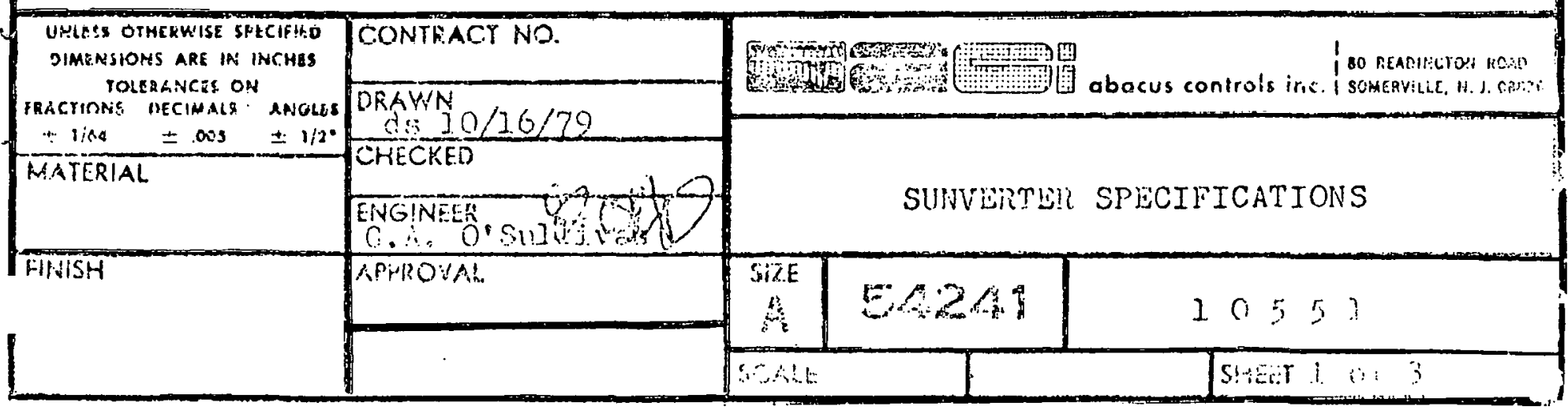

$\mathrm{c}-1$ 
4.8 Autornatic disconnect if phaselock is broken.

4.7 Automatic disconnect on loss of utility.

5. Stand Alone

5.I Three-wire 240VAC $60 \mathrm{~Hz}$ Single Phase.

5.2 Voltage regulation $\pm 2 \%$.

5.3 Voltage is phaselocked to utility voltage if present; otherwise, $60 \mathrm{~Hz} \pm .25 \mathrm{~Hz}$.

5.4 Voltage harmonic distortion: $4 \%$ THD, $3 \%$ maximum any one frequency.

5.5 Automatic disconnect if inverter voltage is less than 2lóvAC.

5.6 Automatic disconnect if inverter voltage is greater than $264 \mathrm{VAC}$.

5.7 Current limit protected and short circuit protected.

CONTROLS AND DISPLAYS

6. Front PaneI

6.1 On-Off Switich

6.2. Mode Select

a. Stand alone (inverter to load)

b. Utility intertie (utility to loud, inverter in parallel when avallable)

6.3 DC On Light

6.4 AC On Light

6.5 Contactor Open (red)

7. Inside Sunverter

7.1 Power level set adjustment (utility mode)

7.2 Contactor Reset

7.3 Contactor on-orf

7.4 Frequency Adjust

7.5 Voltage Adjust 
GEVITAT,

4. 3. îficiency is $87 \%$ or greater from 20; ].oad to full. 10 ad.

9. Tare power is $250 \%$ maximun at 200VDC input.

10. Cooline is forced air as required (fans automatically tumed on anct off by thermal switch)

11. Size is $24 " \mathrm{w} \times 30 " \mathrm{~d} \times 60 " \mathrm{~h}$.

12. Weight is 500 lbs. (1OKVA)

13. Input/output isolation: 1500vaC hipot.

SATETY FEATURES

(These are in addition to automatic turn-offs and disconnects cited above.)

14. DC On-Off Switch

15. Input fuses, both lines

16. Output fuses, both lines

17. Automatic tum-off for power transistos overtemperature. 
APPENDIX D

GENERAL FT,ECTRIC

HOT WATER BANK

INFORMATION SHEET 
The era of energy-awareness has made Americans increasingly knowledgeable about their household energy dollars. It is sobering for them to learn that $1 / 4$ to $1 / 3$ of the household energy is used for domestic hot water. But the facts are inescapable for the family that averages $75 \mathrm{gal}-$ lons of hot water per day, assuming an automatic washer is part of the household.

For a yearly estimate, the daily-average 56,920 Btus are multiplied by 365 , resulting in $20,775,800$ Btus/year, easily equal to $25 \%$ or more of the annual energy consumed to provide comfort for many of today's better built homes.

Reducing the economic burden of paying for over $20,000,000$ hot water Btus would be a welcome benefit for any homeowner. And the Hot Water Bank was created to do just that ... using energy the homeowner has already paid for! The process is called heat recovery ... and it's already well-recognized in industrial plants.

Now the General Electric Hot Water Bank heat recovery unit makes the savings possibilities a reality for the average American home. To understand how it works we need to review the refrigeration process. It can be looked on as a means of collecting heat from one place and transferring it to another. In the summertime heat is collected or absorbed from air in the indoor rooms and transferred or dissipated to the great outdoors.

If the refrigeration system has reversing capabilities, it can provide heating during the wintertime by absorbing or collecting heat from the outdoor air and transferring that heat to the indoor space.

Before America became aware of energy costs, the heat dissipated outdoors was of no great concern. Designs were perfected which lofted hot condenser air up and away from plants and people. It was something to be disposed of as quietly as possible. But energy awareness has made us take another look at that already-paid-for heat. A way was found . . . called a Hot Water Bank . . . to help with the hot water load. Here's how it works:

1. Hot gas from the compressor is routed directly to the Hot Water Bank heat exchanger, which consists of three concentric tubes.

2. Hot gas circulating through the outer tube heats the water from the storage tank as it circulates through the inner tube. An intermediate tube provides additional system protection while speeding up heat transfer from the refrigerant which takes the water temperature up as high as $160^{\circ} \mathrm{F}$. A safety switch in the unit prevents overheating.

3. Hot water is stored in the tank for future use if it is not needed immediately.

So, heat already paid for and formerly thrown away can be used to help heat domestic hot water. A natural question is: How much can it help? For an answer, lets ask the computer. In different cities the percentages range from the mid-seventies to the low eighties ... an impressive portion of the domestic hot water needs during the cooling season. Of course the length of the cooling season will vary. It's over $60 \%$ of the year in Tampa, but urops off to $30 \%$ of the year in Louisville and $25 \%$ of the year in Philadelphia. The more cooling days, the more hours hot gas will be available to heat hot water. At first glance this would seem to give the South a definite edge in Hot Water Bank performance. Actually, more than cooling hours are involved. Fuel costs are also important. It is entirely possible that a Hot Water Bank in a high-energy-cost area could generate more dollar savings in a 150-day cooling season than an application in a 200-day cooling season area with abnormally low energy costs.

But what about winter? The Hot Water Bank can actually be a saver throughout both seasons. Above the thermal application balance point, it can extract heat from the heat pump operation during the winter heating months as well as the summer cooling season. With a heat pump providing year round comfort, the Hot Water Bank tends to be seasonally compensating:

\section{SOUTH: lots of hot gas in summer moderate hot gas in winter \\ NORTH: moderate hot gas in summer lots of hot gas above the balance point in winter}

To calculate summer savings, the computer multiplies the savings per clock hour by the hours in the respective temperature bins to get savings per bin. Totaling the savings for the bins in which the system operates results in a total savings in the cooling season. Dividing the total hours by 24 results in days for the cooling season.

In calculating for Hot Water Bank operation in the heating season, it is important to recognize that $3069 \mathrm{Btu} / \mathrm{hr}$ is approximately $20 \%$ of the heating capacity per ton. However, since the running time in the bins above the balance point will be increased $25 \%$ (calculated run time divided by $80 \%$ of the capacity delivered to the heated space), the figure of $25 \%$ can be used . . . based on the original duty factor or percent run time.

Here again the quantity of heat furnished by the Hot Water Bank per clock hour equals system capacity $x .25 \times$ percent run time (original). The same average maximum of 2372 BTU per hour applies as in the cooling season.

The heat supplied to the water by the Hot Water Bank in the heating season is not "free" as in the cooling mode, but it is produced at an advantageous C.O.P. Taking advantage of the heat pump C.O.P. results in a saving of more than $50 \%$ in most cases. Multiplying the energy (Btu/hr or KWH) furnished to the water by the following ratio indicates the amount of energy saved:

$$
\text { (C.O.P. }-1 \text { ) }
$$

The C.O.P. used is the average for the appropriate bins. An example of the savings calculation for a threeton heat pump in Louisville indicates the following when the outdoor thermostat is set at $37^{\circ} \mathrm{F}$ :

The total winter time contribution to hot water is 7,663,847 BTUs.

This heat is converted to Kilowatt Hours by dividing it by 3413 BTU/KWH, i.e., 7,663,847 BTU + 3413 $\mathrm{BTU} / \mathrm{KWH}=2245.49 \mathrm{KWH}$. The average C.O.P. is 2.71 for the temperature bins in which the Hot Water 
Bank is utilized (See computer printout on page 19). The wintertime savings in Kilowatt Hours is figured by multiplying the total Hot Water Bank contribution, $2245.49 \mathrm{KWH}$, by the ratio $(2.71-1) \div 2.71$ or approximately $1417 \mathrm{KWH}$.

In summary, the Hot Water Bank furnishes $61 \%$ of the domestic hot water needs of a residence in Louisville during the 219 day heating season which comprises all hours below $65^{\circ} \mathrm{F}$.

$$
.61 \times \frac{219 \text { Days }}{365 \text { Days }}=37 \%
$$

WINTER (HEATING) SAVINGS This percentage of hot water is supplied at an economical 2.71 C.O.P. . . . instead of 1.00 as would be the case with an electric hot water heater. See page 19 printout.

SUMMER (COOLING) SAVINGS This percentage of hot

$.77 \times \frac{114 \text { Days }}{365 \text { Days }}=24 \%$ water savings results from recovery of heat ... not from reduced cooling cost. See page 20 printout.
As stated previously, the annual BTU requirement for domestic hot water is:

2372 BTU/HR. $\times 24$ HRS./DAY $\times 365$ DAYS/YEAR or $20,775,800 \mathrm{BTU} / \mathrm{YR}$. This heat is converted to Kilowatt Hours by dividing by $3413 \mathrm{BTU} / \mathrm{KWH}$, i.e., $20,775,800 \mathrm{BTU} \div 3413 \mathrm{BTU} / \mathrm{KWH}=6087 \mathrm{KWH}$.

From the computer printouts on pages 19 and 20 the annual savings using the hot water bank is the sum of the Heating KWH (1417) + Cooling KWH(1489) $=2906$ KWH.

The annual percent of Hot Water Bank Savings is the Total $\mathrm{KWH}$ saved divided by the Total $\mathrm{KWH}$ required annually for domestic hot water, that is, $2906 \mathrm{KWH} \div 6087 \mathrm{KWH}=48 \%$.

It is worth noting that even though the hot water is not "free" during the heating mode, the heating season savings in Louisville are $95 \%$ of the cooling savings.

Over 12.7 of the 20.8 million Btus needed yearly for domestic hot water can be furnished by the Hot Water Bank in this example. On a year round application the Hot Water Bank would save about half of the normal cost for electric water heating. Every homeowner should welcome help like this. It's another example of the way General Electric has used proven technology to bring good things to life.

HOT WATER NEEDS

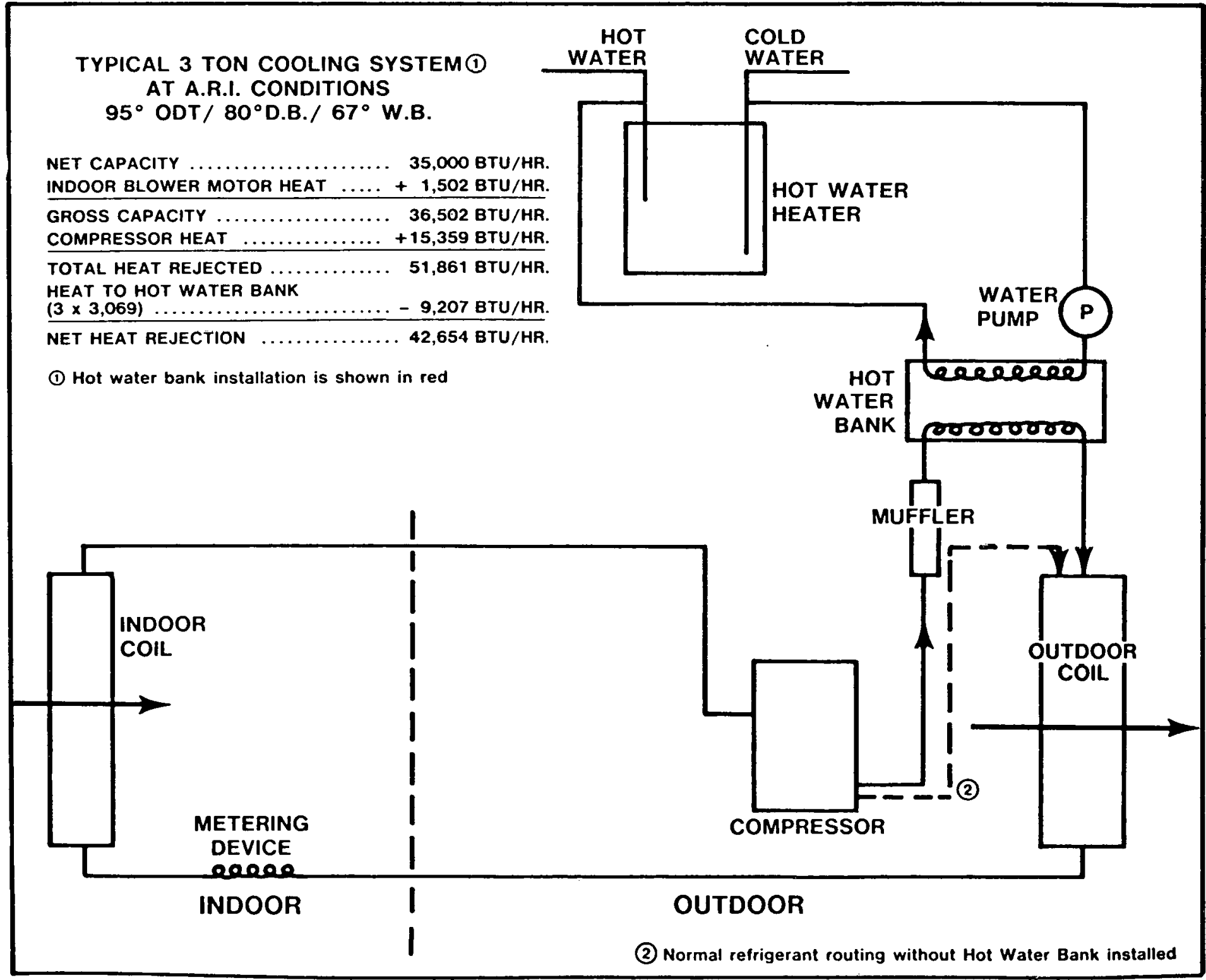


